$M_{2014}$

\title{
EFFECTS OF ACUPUNCTURE ON GAIT OF PATIENTS WITH MULTIPLE SCLEROSIS
}

\author{
MARIA BEGOÑA CRIADO ALONSO \\ DISSERTAÇÃO DE MESTRADO APRESENTADA \\ AO INSTITUTO DE CIÊNCIAS BIOMÉDICAS ABEL SALAZAR \\ DA UNIVERSIDADE DO PORTO EM MEDICINA TRADICIONAL CHINESA
}


Effects of Acupuncture on Gait of Patients with Multiple Sclerosis 


\section{EFFECTS OF ACUPUNCTURE ON GAIT OF PATIENTS WITH MULTIPLE SCLEROSIS}

Dissertação de Candidatura ao grau de Mestre em Medicina Tradicional Chinesa submetida ao Instituto de Ciências Biomédicas de Abel Salazar da Universidade do Porto.

Orientador - Prof. Doutor Henry Johannes Greten Categoria - Professor Associado Afiliação - Instituto de Ciências Biomédicas Abel Salazar

Co-orientador - Mestre Maria João Santos Categoria - Professor Convidado Afiliação - Instituto de Ciências Biomédicas Abel Salazar 
Effects of Acupuncture on Gait of Patients with Multiple Sclerosis 
TO:

JORGE, ANA, INÊS

"Do not be afraid of growing slowly, be afraid of just standing"

Chinese proverb 
Effects of Acupuncture on Gait of Patients with Multiple Sclerosis 


\section{ACKNOWLEDGEMENTS}

Acknowledging, as a feeling, it is very difficult to express with words, but I will try to put into words my deepest acknowledgment to all the persons that gave a significant contribution to this work.

I would like to thank to Prof. Johannes Greten for the orientation of this work, his support and motivation.

To Mestre Maria João Santos, for her encouragement, and permanent help and motivation.

To Prof. Jorge Machado for his help and support.

To my colleagues of the Master in Traditional Chinese Medicine from ICBAS, for their availability to help and friendship.

To Prof ${ }^{a}$ Manuela Neves, for her great contribution to the statistical analysis of this project.

To Prof. Paulo Alexandre Pereira, for his help and collaboration.

To the SPEM and the ANEM for their collaboration. Without their support, this work would not be possible. In particular, to Dr $^{\mathrm{a}}$ Maria José Meyer, $\mathrm{D}^{\mathrm{a}}$ Lurdes, Tânia, Dra Celena and Fátima.

To the clinical direction and the team of the "Clínica Médica de Matosinhos", that kindly let me do the treatments at its facilities.

To all the patients that kindly collaborated in this work. Trying to give some contribution to their wellbeing was the ultimate intention of this work.

To all my friends. They know how important was their support to achieve this work.

To my family, for their constant support and motivation.

To all that in one way or another contributed to this work, my sincere thank you. 
Effects of Acupuncture on Gait of Patients with Multiple Sclerosis 


\section{RESUMO}

Introdução: A esclerose múltipla (ES) é considerada uma doença do sistema nervoso central, complexa e heterogénea desde o ponto de vista clínico. A etiologia da ES é controversa e os mecanismos moleculares subjacentes não são totalmente conhecidos. $A$ disfunção na marcha é um dos sintomas mais debilitantes na ES. Aproximadamente $85 \%$ dos doentes indicam que os problemas da marcha são uma das maiores limitações no seu dia-a-dia.

A acupunctura, como uma forma terapêutica da Medicina Tradicional Chinesa (MTC), regula as funções vegetativas para manter a homeostasia mediante a estimulação de mecanismos de autorregulação. Em alguns estudos de acupunctura foi encontrado uma redução da espasticidade e melhoria da fadiga e desequilíbrio em doentes com ES, mas há uma grande lacuna relativamente à marcha.

Material e Métodos: Baseado no modelo de Heidelberg de MTC, foi desenhado um estudo prospectivo, randomizado e controlado com o intuito de melhorar os problemas da marcha em doentes com ES. A nossa amostra consistiu em 20 indivíduos, todos eles com diagnóstico de ES do tipo surto-remissão (RRMS). Os problemas da marcha foram avaliados pelo teste T25FW (25-Foot test), que mede o tempo utilizado para caminhar uma distância fixa, e é recomendado para ensaios clínicos em ES. O mesmo teste foi realizado mas na forma "pé ante pé". Os doentes foram randomizados de forma cega em dois grupos ( $\mathrm{A}$ e $B$ ). A intervenção em acupunctura foi realizada em dois momentos: num primeiro momento, os doentes do grupo A receberam o tratamento de acupunctura verdadeira, utilizando os pontos ST34, BI40 e BI57, e os doentes do grupo B receberam o tratamento de acupunctura falsa. Num segundo momento, o grupo A recebeu a acupunctura falsa e o grupo B a verdadeira. Antes e depois de cada tratamento, a marcha foi avaliada.

Resultados: Relativamente aos resultados do 25-Foot test, a comparação dos resultados antes e depois do tratamento de acupunctura mostraram diferenças estatisticamente significativas $(p<0.05)$ na acupunctura verdadeira, quando comparado com a acupunctura falsa. Também encontramos que usando acupunctura verdadeira, 95\% dos casos mostraram uma melhoria no T25FW test, comparado com um $45 \%$ quando a acupunctura falsa foi realizada. Na forma pé-ante-pé foram encontrados resultados significativos em ambos os tratamentos de acupunctura. 
Conclusões: Os resultados obtidos no presente estudo apoiam a ideia de que o teste T25FW apresenta suficiente sensibilidade para avaliar o efeito do tratamento, e portanto é uma ferramenta útil como uma medida clínica da marcha em estudos que envolvam acupunctura. Os resultados do teste pé-ante-pé indicam possivelmente que o equilíbrio poderá depender mais da motivação ou expectativas do doente. O nosso protocolo proporcionou evidências de que o tratamento de acupunctura, de acordo com o modelo de Heidelberg de MTC, pode resultar em melhorias na mobilidade. Isto faz da acupunctura, uma alternativa válida para a intervenção em doentes com ES com problemas da marcha que procuram uma terapia eficiente. 


\section{SUMMARY}

Introduction: Multiple sclerosis (MS) is considered a disease of the central nervous system, complex and heterogeneous from the clinical point of view. The aetiology of MS is controversial and the underlying molecular mechanisms are still not completely understood. Gait dysfunction is one of the most debilitating symptoms in MS. Approximately $85 \%$ of patients indicate impaired gait as one of the major limitations in their daily life.

Acupuncture, as a therapeutic form of Traditional Chinese Medicine (TCM), regulates the vegetative functions to maintain homeostasis by stimulating self-regulation mechanisms. In some acupuncture studies a reduction of spasticity and improvement of fatigue and imbalance has been found in MS patients, but there is a lack of studies regarding gait.

Material and Methods: Based on the Heidelberg model of TCM, an acupuncture prospective, randomized and controlled study in cross-over design was done in order to improve gait problems in patients with MS. The sample consisted of 20 individuals, all of them with a diagnosis of MS of relapse-remitting type (RRMS). Gait impairment was evaluated by the T25FW (25-Foot test), a timed walking over a fixed distance measure, recommended for clinical trials in MS. The same test was also done in a tandem walking way. Patients were blinded and randomized into one of two groups ( $A$ and $B$ ). The acupuncture intervention was divided into two moments: in the first one, group A of patients received a true acupuncture treatment, using ST34, BI40 and BI57 points, and patients of group B received sham acupuncture treatment. At a second time, group $A$ received sham acupuncture and group $B$ true acupuncture. Before and after each treatment, gait impairment evaluation was done.

Results: The results of the 25-Foot test, comparing before and after acupuncture, showed statistically significant differences $(p<0.05)$ in true acupuncture, when compared with sham acupuncture. We also found that when using true acupuncture, 95\% of cases show an improvement in T25FW test, compared to $45 \%$ when sham acupuncture was done. Tandem walking test revealed significant results in both acupuncture treatments.

Conclusions: The results obtained in the present study can support the idea that the T25FW test is sufficiently sensitive to assess the effect of treatment and so can be a useful tool as a clinical measure of gait in studies involving acupuncture. The results of tandem walking test possible indicate that balance may depend more on individual 
motivation or expectations. Our study protocol provides evidence that acupuncture treatment, according to Heidelberg model of TCM, can result in improvements in mobility. This makes acupuncture an attractive option for intervention for MS patients with gait impairment looking for effective therapy. 


\section{CONTENTS}

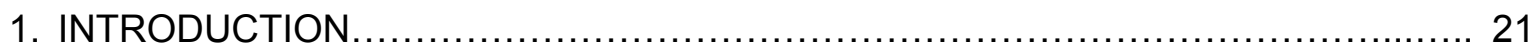

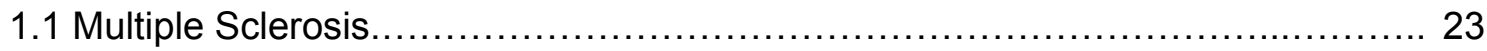

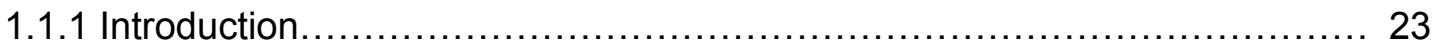

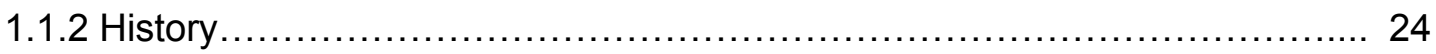

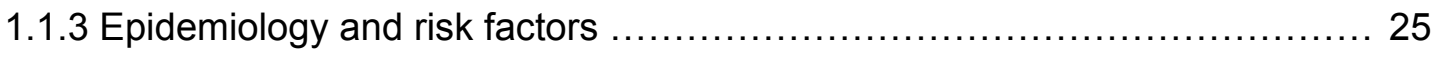

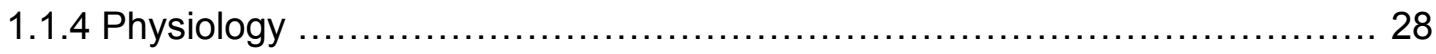

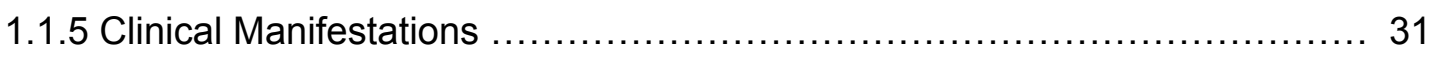

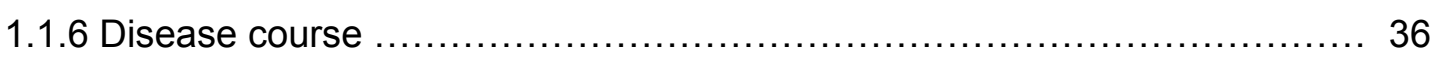

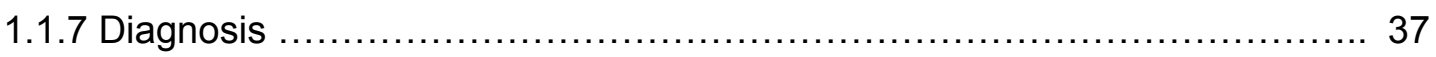

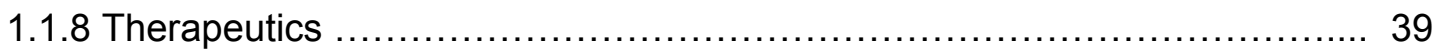

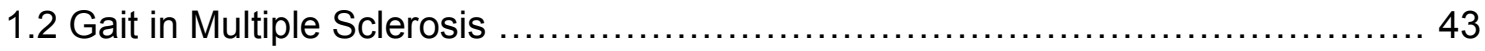

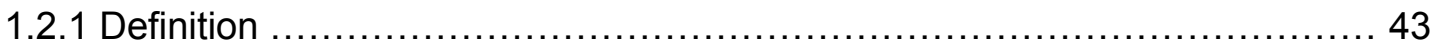

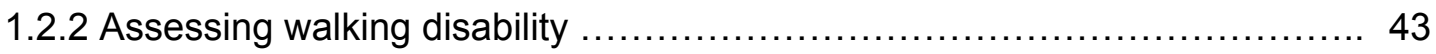

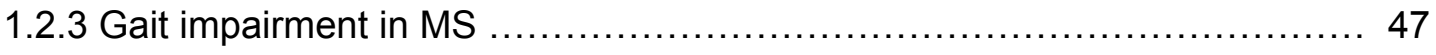

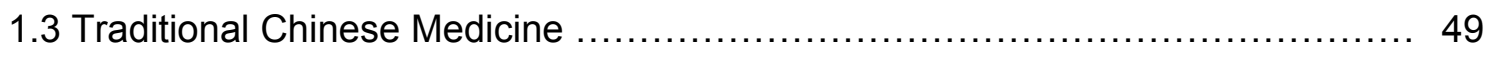

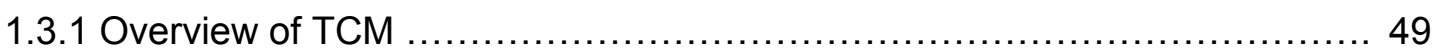

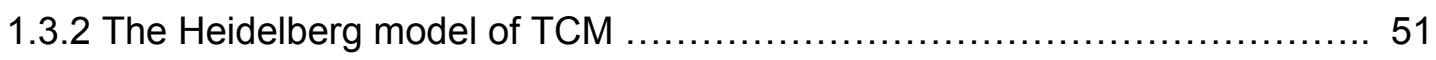

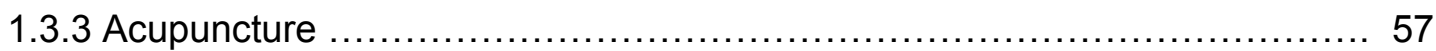

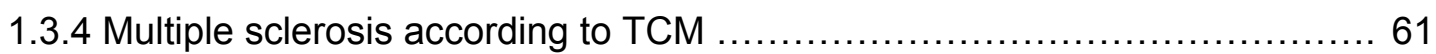

1.3.5 Heidelberg model of TCM and Multiple sclerosis...........................62 62

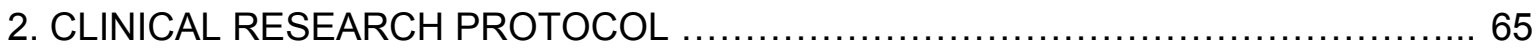

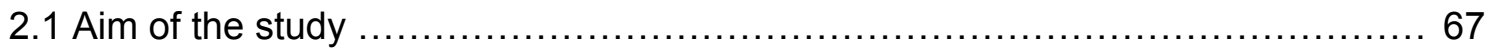

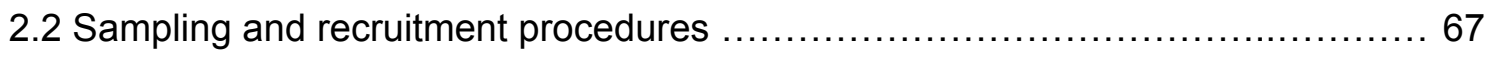

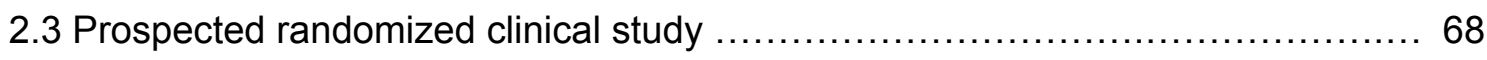

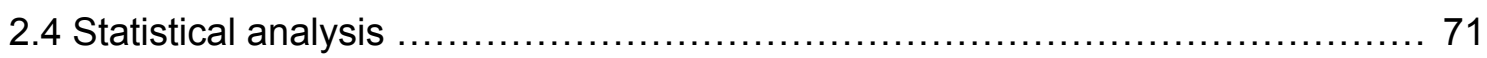

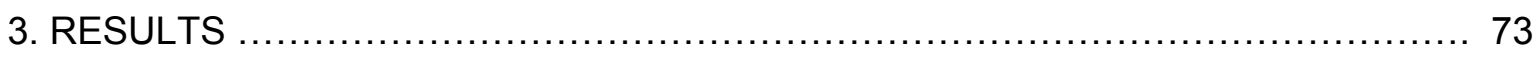

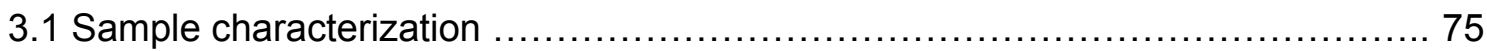

3.2 Gait assessment before and after acupuncture treatment

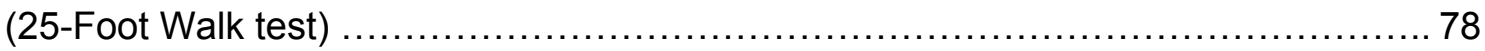

3.3 Gait assessment before and after acupuncture treatment

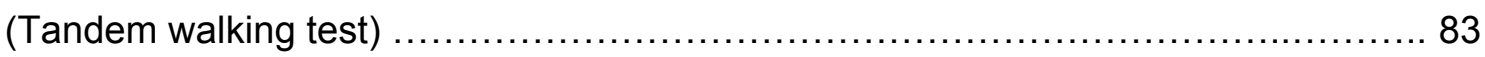

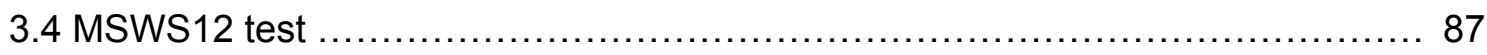

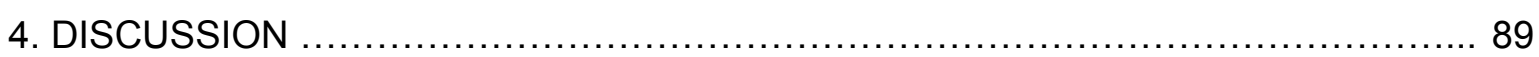

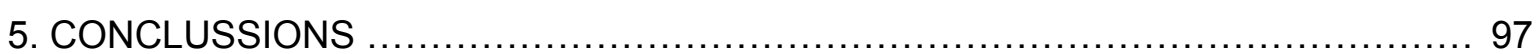




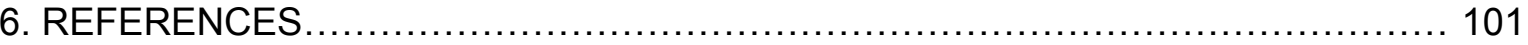

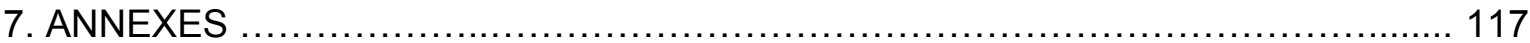




\section{INDEX OF FIGURES}

Figure 1: Schematic representation of pathogenesis of demyelinating lesions in MS

Figure 2: Types of clinical disease progression in MS

Figure 3: Framework of international classification of function (ICF). Mobility in MS.

Figure 4: Schematic representation of the Expanded Disability Status Scale.

Figure 5: Phases Wood, Fire, Metal, Water according to the functional vegetative

state of the organism and its manifestations.

Figure 6: Schematic representation of the components of functional diagnosis

in TCM according to Heidelberg model. 55

Figure 7: The ALT model. 57

Figure 8: Proposed mechanisms of action of acupuncture. 59

Figure 9: MS according to Heidelberg model of TCM. 63

Figure 10: Schematic representation of the selection process 68

Figure 11: 25-Foot walk test (left); Tandem walking test (right). 68

Figure 12: Schematic representation of the intervention process. 69

Figure 13: Anatomic localization of the acupuncture points used in the study according to Heidelberg model of TCM (true acupuncture) ........................ 71

Figure 14: Distribution of the sample according to gender............................. 76

Figure 15: Frequency distribution (\%) of the main complain of the patients................77

Figure 16: Frequency distribution $(\%)$ of the medication used........................... 77

Figure 17: Frequency distribution (\%) of the use of assistive devices................... 78

Figure 18: Mean of the T25FW results (seconds) before and after each acupuncture treatment for the whole sample.

Figure 19: Mean of the T25FW results (seconds) before and after each

acupuncture treatment for male sample

Figure 20: Mean of the T25FW results (seconds) before and after each acupuncture treatment for the female sample.

Figure 21: Percentage of improvement in the T25FW for true acupuncture.

Figure 22: Percentage of improvement in the T25FW for sham acupuncture.

Figure 23: Mean of the Tandem walking test results (seconds) before and after each acupuncture treatment for the whole sample.

Figure 24: Mean of the Tandem walking test results (seconds) before and after each acupuncture treatment for male sample. 
Figure 25: Mean of the Tandem walking test results (seconds) before and after each acupuncture treatment for the female sample

Figure 26: Percentage of improvement in Tandem walking test for true acupuncture

Figure 27: Percentage of improvement in Tandem walking test for sham acupuncture 


\section{INDEX OF TABLES}

Table 1: Classification of diseases according to acupuncture clinical trials of literature.

Table 2: Correspondence between terms in Heidelberg model of TCM and conventional medicine terms.

Table 3: Inclusion/exclusion criteria in the study

Table 4: Socio-demographic and clinical characterization of the sample

Table 5: Descriptive analysis of age, time from diagnosis and the age at diagnosis when considered all individuals of the sample $(n=20)$.

Table 6: Descriptive analysis of age, time from diagnosis and the age at diagnosis for females in the sample $(n=12)$.

Table 7: Descriptive analysis of age, time from diagnosis and the age at diagnosis for males in the sample $(n=8)$.

Table 8: Results of the 25-Foot Walk test before and after true and sham acupuncture

Table 9: Descriptive analysis of T25FW results before and after each acupuncture treatment for the whole sample

Table 10: Descriptive analysis of T25FW results before and after each acupuncture treatment for the male sample

Table 11: Descriptive analysis of T25FW results before and after each acupuncture treatment for female sample.

Table 12: Results of the Wilcoxon test applied to the analysis of T25FW results 82

Table 13: Results of the Tandem walking test before and after true and sham acupuncture treatment.

Table 14: Descriptive analysis of Tandem walking results before and after each acupuncture treatment for the whole sample

Table 15: Descriptive analysis of Tandem walking results before and after each acupuncture treatment for the male sample

Table 16: Descriptive analysis of Tandem walking results before and after each acupuncture treatment for female sample.

Table 17: Results of the Wilcoxon test applied to the analysis of Tandem Walking results. 
Effects of Acupuncture on Gait of Patients with Multiple Sclerosis 


\section{LIST OF ABBREVIATIONS}

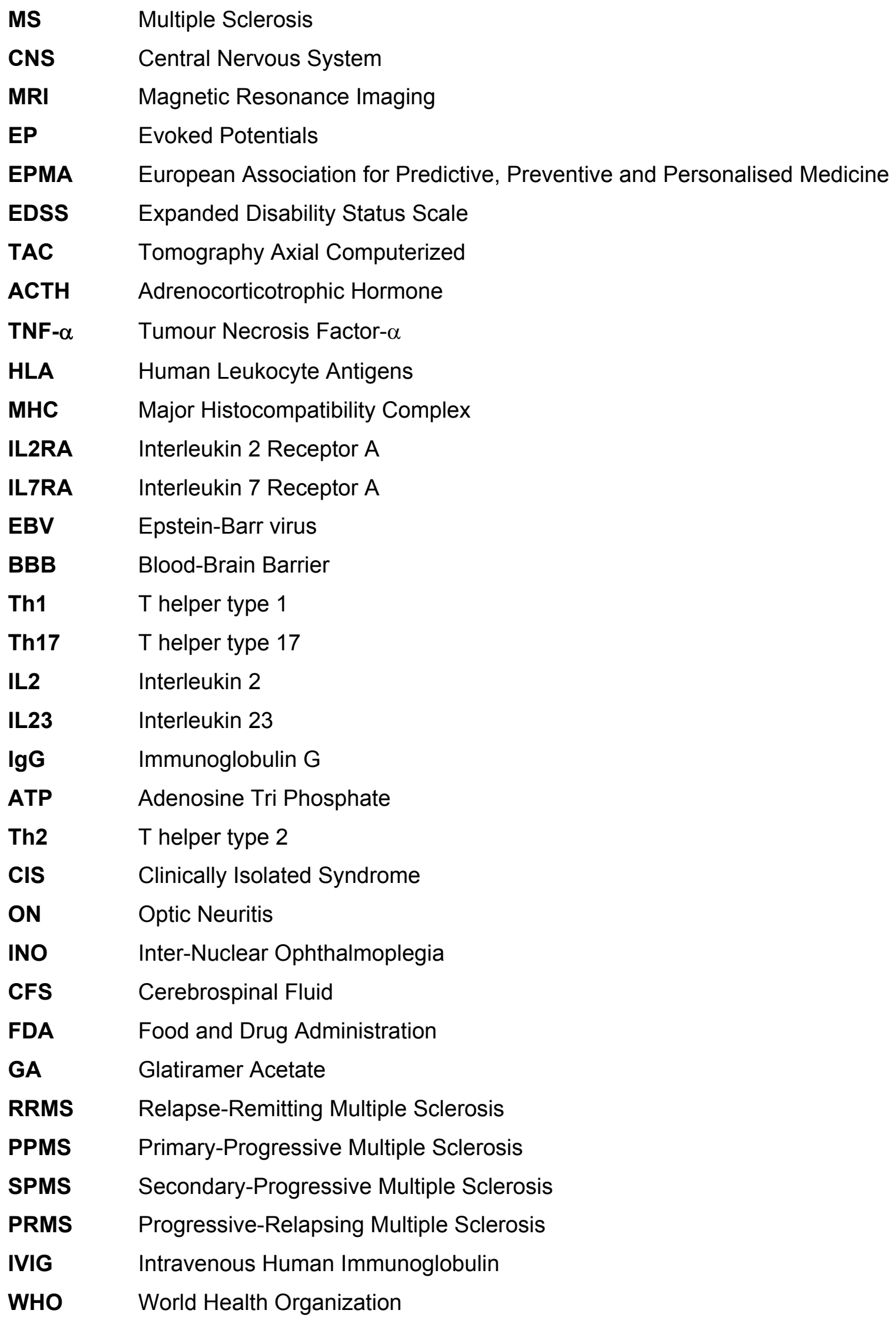


ICF International Classification of Functioning

MSWS-12 Multiple Sclerosis Walking Scale 12

T25FW 25-foot walk test

10MTW 10-metre Timed Walk

30MTW 30-metre Timed Walk

100MTW 100-metre Timed Walk

2mWT 2 minutes Walking Test

6mWT 6 minutes Walking Test

DSS Disability Status Scale

FS Functional Systems

TCM Traditional Chinese Medicine

ALT Algor Leading Theory

CDC Consensus Development Conference

NIH National Institute of Health

GH Growth Hormone

TSH Thyroid-stimulating Hormone

ANEM Associação Nacional de Esclerose Múltipla

SPEM Sociedade Portuguesa de Esclerose Múltipla

SPSS Statistical Package for Social Sciences 
1. INTRODUCTION 
Effects of Acupuncture on Gait of Patients with Multiple Sclerosis 


\section{$1.1 \quad$ Multiple Sclerosis}

\subsubsection{Introduction}

Multiple sclerosis (MS) is an inflammatory, demyelinating neurodegenerative disease of the central nervous system (CNS), considered as the most common cause of chronic neurological disability in young adults (Farias, 2014). MS affects more than 2.5 million people worldwide (Greenstein, 2007). Most MS patients are diagnosed between the ages of 20 and 50 . Risk is greater in women than in men, being the female-male ratio between 1.5 and 2.5 in most populations, with a trend towards higher values (Ascherio et Munger, 2007).

In multiple sclerosis, the loss of myelin (demyelination) is accompanied by a disruption in the ability of the nerves to conduct electrical impulses to and from the brain, what produces the various symptoms of MS. The sites where myelin is lost (plaques or lesions) appear as hardened (scar) areas. These scars appear at different times and in different areas of the brain and spinal cord.

At the present time, there are no symptoms, physical findings or laboratory tests that can, by themselves, make the diagnosis of MS. It is necessary a careful analysis of the patient medical history and rule out other possible causes, as there are symptoms of MS common to other pathologies of the nervous system. Usually, the diagnosis is made according to Mc'Donald criteria, combining clinical manifestations and neurologic exam with various tests including magnetic resonance imaging (MRI), evoked potentials (EP) and spinal fluid analysis (European Multiple Sclerosis Platform, 2014).

Mainly due to its social impact, intensive research is done to elucidate the underlying aetiology and pathogenesis of the disease. Although important advances in our understanding of the cellular and molecular aspects of MS have been achieved, there is still a long way to a comprehensive approach that will uncover treatment and symptom management therapies for everyone (Proceedings of the EPMA World Congress, 2014).

Since MS is a chronic debilitating disease, it imposes enormous costs on patients and on health services. The physical symptoms of the disease and the resulting limitations are associated with strong social and economic impacts, such as reduced productivity, absences from work and a significant economic burden on affected families and the budget of the health system. These consequences are sharpened by the relatively young age of patients in which the disease manifests. In the recent study by Mateus (2010), the 
total expenses per year for a patient with MS relapsing-remitting, with a degree of disability of 6.5 (EDSS), amount to $24199 €$. This amount includes treatment of disease, treatment for side effects, hospital admissions and ambulatory expenses. This figure does not include the indirect costs of the disease, which are estimated to be almost $40 \%$ of the total.

Taking into account these figures and the current socio-economic context in Portugal, it would be of interest to introduce into primary health care complementary therapies for treating the symptoms of MS, less expensive and with fewer side effects than current ones. Of course this will require that national health authorities must ensure safety and competence in their use (WHO, 2010).

\subsubsection{History}

The wide variety and unpredictability of symptoms has made MS a difficult disease to recognize, define, and treat. Since the late 1300s, individuals with a progressive illness suggestive of MS have been observed, but it wasn't diagnosed until 1868 that the famous neurologist Jean-Martin Charcot lectured on the features of MS and gave it a name. Multiple sclerosis was officially recognized as a disease in the 1870s (Multiple Sclerosis Association of America, 2014). Some cases were diagnosed in Europe and United States, but for almost half of a century it continued to be considered as a rare disease. At the beginning of the XX century the term "Multiple Sclerosis" was introduced in Germany but was only well-established in the middle of the century. Walter Moxen and Edward Seguin found that multiple sclerosis affected females more often than males and also determined that MS was not strictly genetic (Multiple Sclerosis Association of America, 2014).

In 1935, the pieces of the MS puzzle started to come together. Thomas Rivers proved, through experiments with lab animals, that MS was not a viral disease, but one of the immune system. Still, only in the 1960s there was the idea that the immune system attacked the myelin coating of the nerves, and thus acted like an autoimmune disease. In 1965 George Schumacher and a group of experts established criteria for the diagnostic. These criteria were replaced in 1983 by the ones of Poser, which integrated TAC imaging and cerebrospinal fluid laboratory data. Poser criteria were used until 2001 when they were replaced by McDonald's. These criteria, which emphasize the visible alterations on MRI, were updated in 2005 in order to enable an early diagnostic and settings of relapse, spread and positive MRI (Bigotte de Almeida, 2010). 
The first clinical trial for acute relapsed was performed in 1970. It evaluated the efficacy of the ACTH in the stimulation of corticosteroids in order to obtain an anti-inflammatory and immunosuppression effect. The 1990s could be named the "drug explosion" decade in terms of MS treatments. Interferon was approved as a treatment for relapsing-remitting MS and cortisone was used to treat MS relapses (Multiple Sclerosis Association of America, 2014). In 2004 was introduced the first selective inhibitor of adhesion molecules (Natalizumab) with the finality to block the entrance of inflammatory factors in the nervous compartment (Bigotte de Almeida, 2010).

The new millennium brought new theories and the amount of information available about MS has grown exponentially in recent times. Nevertheless, more research is still needed to continue to find a cure for this chronic, unpredictable disease. Better treatments to prevent further progression and to repair the nervous system and restore function, and better management of symptoms must be a high priority to improved quality of life for people who live with MS every day.

\subsubsection{Epidemiology and risk factors}

Multiple sclerosis is probably one of the most studied neurological diseases from the epidemiological point of view. However, doubts remain about the real prevalence and incidence of MS.

In 1975, Kurtzke introduced the concept of "latitude gradient" based on the fact that the prevalence of MS increases with distance from the equator in both hemispheres (Kurtzke, 1977). According to this concept MS would be more common in Europe, North America, Australia and New Zealand, with prevalence higher than 50 per 100,000 populations. On the contrary, it would be rare in the East and infrequent in Africa and South America. However, recent epidemiological studies do not support this view of the worldwide distribution of multiple sclerosis. Population studies conducted in Italy showed prevalence rates much higher than the original figures (40-70 per 100,000) (Maddestra, 1998). Also, in Spain prevalence rates of 32-65 per 100,000 have been found (Uria et al, 1997). In Portugal, a study of De Sa et al. (2006) found a prevalence of 46.3 per 100,000. Another study performed in 2011 revealed a prevalence of 54 per 100,000 (Pinheiro and Guimarães, 2011) and more recently, in 2012, a study in the region of Lisbon showed a prevalence of 41.4 per 100,000 (De Sá et al, 2012). Thus, the distribution of multiple sclerosis in Europe, and in the world in general, seems to be more complex than previously thought. There are important differences in prevalence between areas with the same latitude and even within the same country (Pugliatti et al, 2006). Several studies 
have also reported increasing incidence over time, although these data can be biased by heightened awareness of the disease and new diagnostic techniques (Compston and Coles, 2008).

The geographical distribution of MS, especially with respect to latitude, raises the question if climate factors could be a causative factor of MS. In that sense, a correlation between solar radiation and a reduced risk of MS in several regions has been documented, while other studies have not found such association. Some studies have confirmed that sun exposure was consistently associated with a lower risk of MS (van der Mei et al, 2003). Taking into account that ultraviolet light promotes the production of vitamin $D$, the mechanisms of favourable effects of vitamin D in MS are not entirely known, but could be related to the ability of $1.25(\mathrm{OH})_{2} \mathrm{D}_{3}$ to inhibit the production of the Th1-associated cytokines interleukins-12 and 2, interferon- $\gamma$ and TNF- $\alpha$, thus suppressing the development and proliferation of the inflammatory Th1 cells (Lemire et al, 1995; Munger et al, 2004).

Although little is known about the aetiology of the MS, it is highly unlikely that the disease results from a single causative event. According to current knowledge, genetic and environmental factors are involved in its pathogenesis (Farias et al, 2014). As is the case for most neurodegenerative diseases, there is strong evidence to support the idea that MS is a disease with a complex genetic background upon which environmental triggers act. Studies in different countries have clearly shown that first-degree relatives of patients with MS have an increased risk of developing the disease. Also, studies of monozygotic twins with MS have shown that the monozygotic twin of a MS patient has more than 100 -fold higher risk than the general population (Sadovnick et al, 1996). It has been proposed that the inheritance of MS is multigenic and affected by multiple loci (Holmes et al, 2005; Sawcer, 2006). Although these results suggest the presence of a genetic component, they also show a further important contribution of environmental factors.

In spite of an intensive search in recent decades of genes related to multiple sclerosis, the only consistent association refers to the class II alleles of the Human Leukocyte Antigen (HLA), which is part of the major histocompatibility complex (MHC) region, particularly HLA-DR2 haplotype, HLA-DRB1 and HLA-DQB1 alleles (Veloso, 2010). An association with class I alleles, also initially proposed, is less consistent. A study of genomic association published by the International Multiple Sclerosis Genetics Consortium (2007) has shown that the HLA-DR locus is associated with MS. An association with alleles of the receptors of Interleukin-2 (IL2RA) and Interleukin-7 (IL7RA) was also found. As these 
alleles have also been implicated in the pathogenesis of other diseases, such as Type I diabetes and Graves' disease, these results gave additional evidence that MS is an autoimmune inflammatory disease.

Although genetic predisposition can probably contribute to geographical variations in the distribution of MS, it does not explain the differences in risk observed among populations who migrated from areas of low to areas of high disease prevalence, and vice versa. For example, in South Africa, the prevalence of MS is relatively high among European and low among African immigrants. Apparently, those who migrated from Europe into adulthood carried the high prevalence of their country of origin, while those who immigrated in childhood show a similar prevalence of local population (Compston and Coles, 2008). With respect to immigration to areas of high prevalence, children born in the UK of African, Asian and West Indian origin had a prevalence of MS similar to the equivalent Caucasians age groups (Elian et al, 1990). Thus, studies with migrants suggest that exogenous factors have a significant influence in the development of MS and that environment exposure would be particularly relevant in adolescence, although it is not clear whether these factors act as a trigger of the disease or are involved in its pathogenesis. In this context it has been suggested that infection could be an important agent, particularly early infectious diseases like measles, rubella, mumps and varicella. Nevertheless, epidemiological studies do not support a clear association between these diseases and MS (Ruth, 2004).

Epidemiological findings of a latitude gradient, the apparent protection for MS individuals born in low-risk areas who migrate to areas of high-risk and a higher incidence of MS among groups of higher economic level and education, could be explained by the idea that, to develop normally, the immune system needs to be stimulated early in the individual's life (Veloso, 2010). In developed countries, vaccination, the widespread use of antibiotics and a better health care reduce infections in childhood; as a result, there would be a greater tendency to develop autoimmunity later in life (Bach, 2002). However, the socalled "the hygiene hypothesis" is contradicted by the role that some infections have in autoimmunity, namely the association between infection by Eptein-Barr virus (EBV) and a significant increased risk of MS (De Jager et al, 2008).

Ascherio and Munch (2000) gave evidences that almost all MS patients (>99 \%) are infected by EBV, compared with about $90 \%$ of the control population. Other studies have confirmed an increased risk of MS after infectious mononucleosis (Thacker et al, 2006). Also, it seems that an association between disease activity and reactivation of the virus 
exists. Association of other neurotropic viruses, such as the Herpes Types I and VI, with MS have also been found, suggesting that multiple agents may play a role in the pathogenesis of MS and the clinical course of the disease, presumably by immune mediation mechanisms (Veloso, 2010; Ascherio and Munch, 2007).

In summary, MS is a very complex disease, probably due to an interaction of genetic and environmental factors. Existing biological and epidemiological data seems to confirm the existence of genetic susceptibility to MS, making also clear the importance of environmental factors among which stand out the sunlight/vitamin $D$ and infectious agents, including Epstein-Barr virus.

\subsubsection{Physiopathology}

Classically, multiple sclerosis has been known as an autoimmune disease. Although the involvement of the immune system in the physiopathology of the MS seems to be evident, it remains unclear in what extent MS is an autoimmune or just an immune mediated disease (Fontoura, 2010). Recent literature and in vitro and in vivo studies have shown that there are other factors involved in the pathogenesis of the disease and there is not a unique cause. In other words, multiple sclerosis is a multifactorial disease (BolañosJimenez et al, 2011).

Inflammation, demyelination and remyelination, oligodendrocyte depletion and neuronal and axon degeneration are the major pathologic mechanisms that leads to the formation of the sclerotic plaque, the hallmark of a demyelinating disease like MS. However, the order and relation of these parts of the process remain unclear.

The blood-brain barrier (BBB) is an anatomical and functional barrier that protects the encephalon against microorganisms, toxins and other agents. In multiple sclerosis, there is a disruption of this barrier, allowing lymphocytes and other cells and factors involved in inflammation, namely molecules of the major histocompatibility complex (MHC) class II, citokines, immunoglobulins, complement molecules and nitric oxide, to enter the central nervous system and start the inflammatory process (Bolaños-Jimenez et al, 2011). Activation of T CD4+ cells in the periphery and subsequent generation of Th1 is the first step of the process. These autoreactive $T$ cells interact with adhesion molecules on the endothelial surface of the CNS and cross the disrupted BBB with the aid of matrix metalloproteinases and chemokines. B cells and monocytes are also involved. The failure of local regulation of these immune components, by either receptor activation or cytokine 
release, triggers the pathogenic process at particular sites of inflammation dominated by cell infiltrates (Figure 1).

Inflammation seems to be driven by $\mathrm{T}$ helper 1 (Th1) and the subtype that secretes interleukin-17 (Th17) under interleukin-23 control (Kebir et al, 2007; Tzartos et al, 2008). Which antigen starts this response is an unknown matter up to now, but putative antigens include myelin basic protein, myelin-associated glycoprotein, myelin-oligodendrocyte glycoprotein, proteolipid protein, ab-crystallin, phosphodiesterases and S-100 protein (Tullman, 2013).

The central role of Th17 produced citokines in the brain is the induction of inflammation characterized by immune cells recruitment, enhancing microglia activation and myelin loss (Iwakura and Ishigame, 2006). As immune cells accumulate, pro-inflamatory citokines like IL-2, IL-23, interferon $\gamma$, TNF $\alpha$ amplify the immune response. Together with these inflammatory citokines, proteases, free radicals, antibodies, nitric oxide, glutamate and other stressors that collectively lead to damage of myelin and oligodendrocytes are also involved (Tullman, 2013). Besides pathogenic lymphocytes, some regulatory cell populations with an important role in the control of the autoimmune response, are present. That is the case of the Treg T CD4+cells. Some studies verify the suppressor potential of these cells on the inflammatory process, but although these cells are present in demyelinised lesions, their function is not enough to antagonize the effect of other cell populations (Korn et al, 2007).

Contact is established between activated microglia and components of the oligodendrocytes-myelin unit that is opsonised with ligands for microglial Fc and complement receptors. Cell surface bound TNF- $\alpha$, which constitutes a lethal signal (Compston and Coles, 2008) (Figure 1).

The demyelination process represents an initial phase of the chemical lesion, with dissolution of myelin by antibodies and complement factors. The presence of IgG capping of macrophages suggests that antibody-mediated phagocytosis of myelin may play a role in the pathogenesis of the disease (Greenstein, 2007). Then, desegregation of the myelin forms spheroids that are removed by macrophages. The lesion enters in a chronic phase in which the inflammation and demyelination stops. The plaque reveals at this moment loss of oligodendrocytes. These cells seem to die through necrosis and apoptosis (Figure 1). 
Luchicetti et al. (2011) described four different patterns of demyelination in MS, taking into account: the distribution of myelin loss, the geography of the plaques, the extension and pattern of destruction of oligodendrocytes and $\lg G$ deposition evidence and activation of complement. The most common type, pattern II, was characterized by the deposition of immunoglobulin and complement. Pattern I was characterized by macrophage-associated demyelination. In patterns III and IV, demyelination was due to oligodendrogliopathy. Pattern III was differentiated from pattern IV by a preferential loss of myelin-associated glycoprotein. In the same individual, all lesions have only one of these four patterns, but there was marked heterogeneity between patients, suggesting that MS might have multiple pathogenic mechanisms (Tullman, 2013).

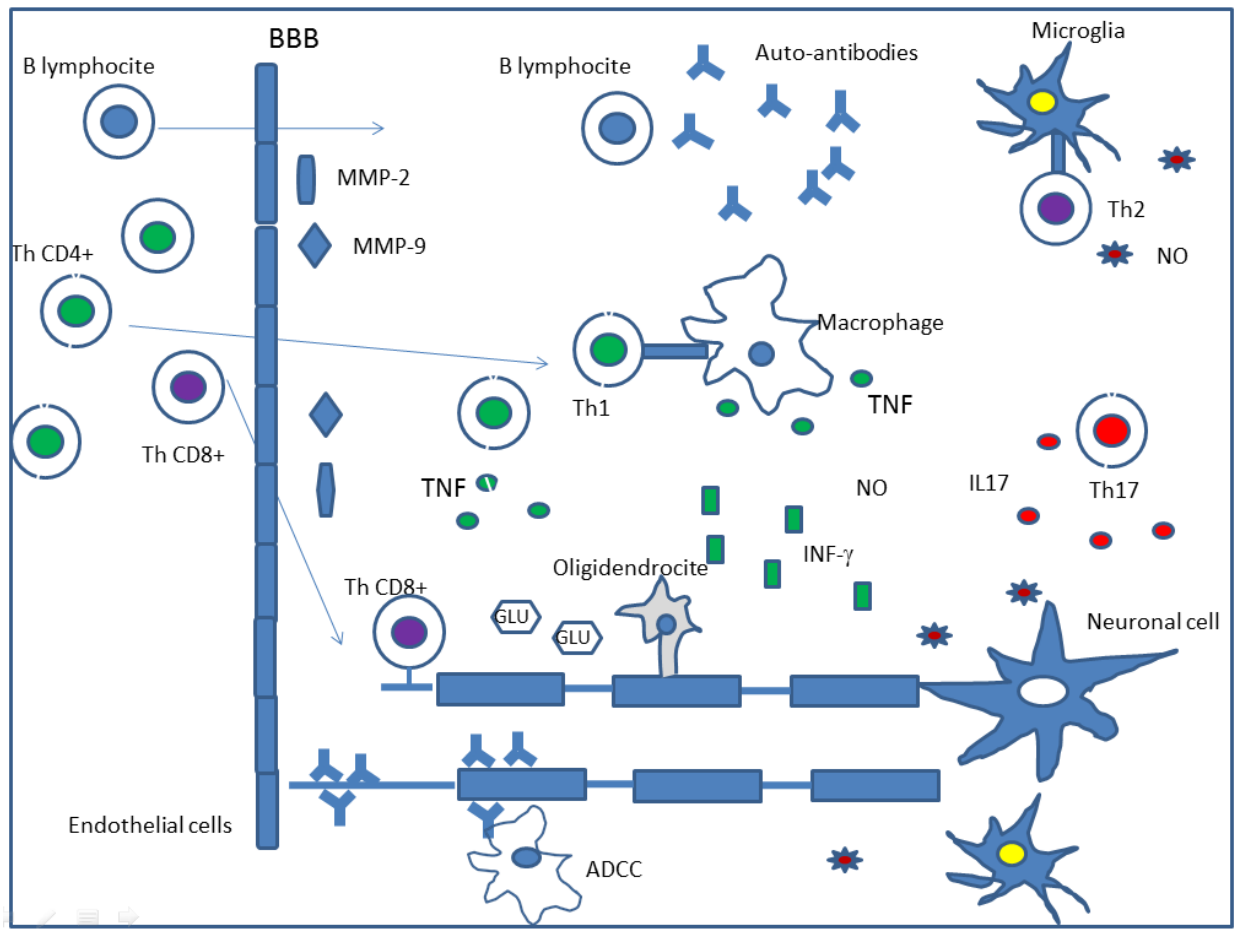

Figure 1: Schematic representation of pathogenesis of demyelinating lesions in MS. Adapted from Fontoura (2010).

In $20 \%$ of MS patients plaques are eventually remyelinated. Remyelination happens because the mature nervous system maintains a pool of oligodendrocytes precursors that can surround the lesions and presumably act as the source of cells having the potential to remyelinate naked axons (Chandran et al, 2008). Nevertheless, successive cycles of demyelination and remyelination can exhaust the capacity for tissue repair.

$\mathrm{T}$ and $\mathrm{B}$ cells, as well as macrophage activity, are responsible for tissue injury. Lymphotoxins and TNF- $\alpha$ are cytotoxic to oligodendrocytes. Nitric oxide leads to necrotic death of oligodendrocytes, reversible conduction block in axons, inhibition mitochondrial 
respiration, increasing intra-axonal $\mathrm{Na}^{+}$and activating the $\mathrm{Na}^{+} / \mathrm{Ca}^{++}$exchanger, which triggers a cascade leading to axonal degeneration (Greenstein, 2007). Elevated glutamate levels are present in active MS lesions and it is also involved in the damage to oligodendrocytes, myelin and axons (Micu et al, 2006).

Remodelling of the axonal membrane both during acute and chronic demyelination is present and probably contributes to the development of axonal degeneration. As alterations in $\mathrm{Na}^{+}$channels occurs, $\mathrm{Ca}^{++}$entries into axons with subsequent production of injury. The increase in axoplasmic $\mathrm{Ca}^{++}$activates proteases fragmenting neurofilaments and depolymerizating microtubules (Stys, 2004). Also, reduced mitochondrial respiratory complex I activity is present in chronic active MS lesions (Lu et al, 2000). The reduced activity of mitochondria leads to decreased ATP production, which can be an additional factor leading to axonal degeneration (Dutta et al, 2006). Oligodendrocytes provide trophic support for axonal function that fails when some myelin proteins are lost.

The resulting transient dysfunction of demyelination explains the symptoms and signs present during the clinical relapses, while axonal injury is responsible for the progressive and irreversible clinical worsening characterizing the two types of clinical evolution (relapses and progression).

Further studies are needed to understand the complexity and heterogeneity of the immunopathogenesis of the disease. The pathologic variability indicates MS clinical variability and reinforces the need of new treatment strategies that includes preventing axonal loss and the inflammatory process due to lymphocytes $\mathrm{T}$ and macrophages. Demyelination must be avoided by acting in the process antibody-complement and inhibiting proinflamatory citokines. It is also necessary to promote the remyelination, induce the oligodendrocytes and stimulate Th2 suppression citokines.

\subsubsection{Clinical Manifestations}

The clinical manifestations of MS are highly variable and unpredictable. There are no clinical findings that are unique to MS, but some are highly characteristic of the disease. About $80 \%$ of patients present a "clinically isolated syndrome (CIS)", term used to describe a first episode of neurologic symptoms, that lasts at least 24 hours, in one or more sites in the central nervous system. CIS can be either monofocal or multifocal, depending if a single neurologic symptom is present, or more than one. Individuals that experience a CIS may develop MS. When CIS is accompanied by MRI-detected brain lesions, similar to those seen in MS, the person has a high likelihood of a second 
neurologic event and a diagnosis of MS within some years. When CIS is not accompanied by MRI-detected lesions, the person has a lower likelihood of developing MS (National Multiple Sclerosis Society, 2014).

According to the National Multiple Sclerosis Society (2014) the most common symptoms of MS include: vision problems, fatigue, numbness and tingling, weakness, dizziness and vertigo, pain, sexual problems, emotional changes, gait difficulties, spasticity, bladder and bowel problems, cognitive problems and depression. Less common symptoms include: speech problems, tremor, breathing problems, headache, swallowing problems, seizures, itching and hearing loss.

\section{Sensory symptoms}

The most common initial symptoms largely reflect the involvement of sensory, motor and autonomic pathways in the brainstem/cerebellum and the optic nerve. One of the most common symptoms is the presence of numbness or paresthesias in a member. Typically, changes in sensitivity are noted in distal regions, then progressing to the proximal segments and side members. Symptoms are commonly described as numbness, tingling, pins-and-needles, tightness, coldness or swelling of the limbs or trunk.

Pain is a common disease manifestation throughout the disease. In the study of O'Connor et al. (2008), the estimated prevalence of pain is $50 \%$. The pain can be caused directly by the demyelinating lesions (primary) or be related to the physical limitations of the disease or treatment (secondary). The diversity of the causes of pain makes it difficult to classify, being generally categorized according to the underlying pathogenic mechanisms: neuropathic pain vs musculoskeletal, an important distinction for selecting the most appropriate treatment (Pollmann and Feneberg, 2008). Also, the coexistence of different types of pain is rather common.

The Lhermitte phenomenon is described as an electric shock radiating down the spine or into the limbs with flexion of the neck. This symptom happens in up to $40 \%$ of the patients throughout the course of the disease, but it can also be seen in other lesion of the cervical cord (Kanchandani and Howe, 1982).

\section{Motor symptoms}

The motor symptoms are less common than the sensitive ones, but have more serious consequences, representing the leading cause of disability in progressive stages of the disease. Deficits result from the involvement of pyramidal pathway (cortical-spinal and 
cortico-bulbar descending pathways) by lesions with a hemispheric or medullary location. The pyramidal signs are among the most common abnormalities in patients with MS. They are often bilateral and asymmetrical. The worsening of muscle weakness is associated with spasticity, which generates increased difficulties to gait and posture. The increased tone in the extensor muscles can determine the presence of spasms, particularly in the cubital position and at the beginning of the movement. Spasticity significantly worsens with the onset of pressure ulcers and urinary tract infections.

For movement disorders, tremor of action and dyskinesia or paroxysmal tonic spasm is common. A prevalence of $37 \%$ of tremor and $20 \%$ of tonic spasms was described by Vale (2010).

The cerebellar symptoms are common in MS, usually appearing some years after the onset of the disease. Gait imbalance, difficulty in performing coordinated actions with the arms and slurred speech may occur as a result of impairment of cerebellar pathways. Cerebellar signs are usually mixed with pyramidal (cortical-spinal) tract signs (Olek, 2014).

\section{Visual symptoms}

Optic neuritis $(\mathrm{ON})$ is the most common type of involvement of the visual pathways in relapse-remitting form of MS. Optic neuritis is present as an initial manifestation in $20 \%$ of the cases (Confavreux et al, 2003).

Typically ON manifests by acute loss of monocular vision associated with local pain. Pain precedes or accompanies the visual complains. It is referred to the orbital or frontal-orbital region and significantly worsens with eye movement and pressure of the eyeball. Vision loss settles in hours or days and a greater commitment of central vision (scotoma) is noted. The degree of vision loss is very variable. When vision is relatively preserved, colour vision and contrast sensitivity are the most altered. Other symptoms may be photopsias and sometimes a feeling of visual distortion when in motion, a phenomenon associated with the presence of different driving speeds in optical pathways (Burke et al, 2001).

Physical examination of patients with $\mathrm{ON}$ reveals a relative afferent pupillary defect (Marcus Gun pupil). Disc oedema may be observed on fundus examination. Most often the lesion of the optic nerve is retro-bulbar, and fundus examination is normal in the acute stage. Later, the optic disc becomes pale as a result of axonal loss and resultant gliosis. 
$90 \%$ of patients recover vision over a period of two to six months after an acute episode of ON (Olek, 2014).

MS can cause a wide variety of ocular-motor changes, the inter-nuclear ophthalmoplegia (INO) and cerebellar changes of the look being the most frequent. Inter-nuclear ophthalmoplegia refers to abnormal horizontal ocular movements with lost or delayed adduction and horizontal nystagmus of the abducting eye. A bilateral INO in a young adult represents the most characteristic signal of MS, but it can be observed in other intraaxial brainstem lesions (Olek, 2014).

\section{Sphincter/sexual dysfunction}

Bowel, bladder and sexual dysfunction are common in MS.

The alterations of the bladder control are mainly related to the presence of lesions in the hypothalamus, brainstem and spinal cord, which interrupt the central control circuits and the sympathetic and parasympathetic pathways (Vale, 2012). The most common symptom is urinary urgency, reported by $75 \%$ of patients and associated with a persistent increase in detrusor activity which causes a reduction in bladder volume. This increases the frequency of urination with nocturia and urinary incontinence appears (Haensch and Jorg, 2006). In other cases the complaints relate to the difficulty of emptying. In these cases, there is a simultaneous activation of mechanisms that empties the bladder and those that close the sphincter due to the spinal cord injuries. The residual volume also increases, causing incontinence. There are also frequent recurrent urinary tract infections, particularly in women, that may increase the extent of bladder dysfunction. The frequency of urinary symptoms increases with age and disease duration and is often associated with spasms of the lower limbs (de Sèze et al, 2007).

The majority of MS patients refer also alterations in bowel function: faecal incontinence and constipation. Constipation is more common than faecal incontinence. These problems may be a result of both upper and lower motor neuron impairment, in addition to a decrease in general mobility.

Sexual activity is often altered in patients with MS, independently of gender. The disability associated with the disease leads to difficulties in the affective relationship and sphincter dysfunction. Changes in sensation, pain and spasticity of the lower limbs and pelvic floor directly interfere with sexual performance. The most frequent alteration identified is erectile dysfunction, which affects about $40 \%$ of patients with less than 30 years old 
(DasGupta and Fowler, 2002); decreased libido and inability to achieve orgasm are also common (Nortvedt et al, 2007).

\section{Fatigue}

Fatigue is defined as a feeling of lack of physical or mental energy that interferes significantly with the performance of daily activities. It affects about 85 to $90 \%$ of patients that referred it as the most disabling symptom of the disease. It is characterized as a feeling of exhaustion, weakness or excessive sleepiness that tends to follow a circadian rhythm and is accentuated with heat (Uthoff phenomenon) and physical activity. Fatigue can manifest at any stage of the disease and seems to be determined by a decrease in voluntary muscle activity by bankruptcy of the central mechanisms that generate motor activity (Greim et al, 2007).

\section{Cognitive dysfunction}

Although cognitive changes have been described by Charcot in the first descriptions of MS, only from the last few decades they are no longer regarded as a minor manifestation of the disease. It is currently reported a $45-65 \%$ of patients with cognitive disorders that has a major impact on their quality of life (Calabrese, 2006). The clinical presentation is variable and may range from mild cognitive impairment to a rare case of severe disability (Piras and Solinas, 2003). They can be found from the early stages of the disease and may have a variable course (Kujala et al, 1997).

The functions most frequently affected are memory, attention, and speed of information processing and executive capacities. These changes can fit into a pattern of subcortical dysfunction due to multiple neuronal network disconnections in the presence of demyelinating lesions (Calabrese 2006).

Neuropsychological assessment allows to quantify the nature and severity of cognitive deficits, which are not easily detected in routine consultations, and hence the need to include it as an additional study in the framework of a multidisciplinary clinical evaluation component (Silva, 2012).

Depression is the most common psychiatric manifestation in MS. Some authors indicate that it can affect nearly $50 \%$ of patients over the disease. It is believed that it has a multifactorial origin, but may also be related to the presence of persistent inflammation or with the localization of brain injury (Foong and Ron, 2003). 
The symptoms of multiple sclerosis can be different from person to person. Visual, sensory, and motor signs and symptoms are all part of multiple sclerosis. The clinical manifestations are varied, and therefore there is a wide range of symptoms that can appear. Some people have mild cases of multiple sclerosis with little or no disability over the years. Others have more severe types, requiring confinement to a wheelchair or bed.

\subsubsection{Disease course}

The current MS classification system is based on consensus and relies on the clinical criteria since we do not have enough knowledge that enables an etiopathologic or physiopathologic classification (Pinto Marques, 2010).

Clinically, the two basic events that mark the disease are relapse and progression. Relapse is defined as the occurrence, recurrence or worsening of a neurological dysfunction that has a duration equal or superior than 24 hours. After reaching the peak, the dysfunction stabilizes and is followed by a recovery that may be complete or partial. All neurological changes in a month will be considered as being the same relapse.

The term progression in MS means a continuous worsening of symptoms for a period of at least 6 months. Periods of stabilization may occur or overlapping outbreaks.

Currently, the following definitions of types of clinical disease progression are used (Lublin, 1996): Relapsing-remitting, primary-progressive, secondary-progressive and progressive-relapsing (Figure 2)

\section{Relapsing-remitting MS (RRMS)}

This form accounts for $70 \%$ of patients with MS (Pinto Marques, 2010). It is characterized by acute relapses interspersed with periods of clinical remission that are characterized by a lack of disease progression.

\section{Primary-progressive MS (PPMS)}

This form is characterized by a progression of the disease from the onset. The rate of progression may be variable and there may exist periods of stabilization, but not well defined relapses occur. It accounts for about $10 \%$ of the cases. It is more frequent in older adults with the same prevalence in men and women (Tullman, 2013, Pinto Marques, 2010). 


\section{Secondary-progressive MS (SPMS)}

It is characterized by progression after a period of evolution by relapses. The existing deficits cannot be explained only by the accumulation of the symptoms of relapses with incomplete recovery. There is a continuous deterioration of neurological functions. This form constitutes 15 to $20 \%$ of all forms at a given time (Pinto Marques, 2010).

\section{Progressive-relapsing (PRMS)}

Progressive-relapsing multiple sclerosis is characterized by progressive disease from onset, with clear acute relapses, with or without full recovery. Progression continues during the periods between relapses. This type of MS is the less common form of the disease being responsible for about $5 \%$ of the cases (Olek, 2014, Tullman, 2013).

From this classification we can say that there are two ways for the clinical onset of the disease: relapse-remitting or primary-progressive. From these forms there may be or not evolution of the disease to secondary-progressive or progressive-relapsing, respectively. When we talk about a particular patient with a particular form of MS, this should be understood as a form of clinical manifestation of the disease at that time. The same patient may change its clinical presentation and later evolve into another form. Thus, it might be more correct to speak of clinical stages of the disease rather than forms of the disease (Pinto Marques, 2010).
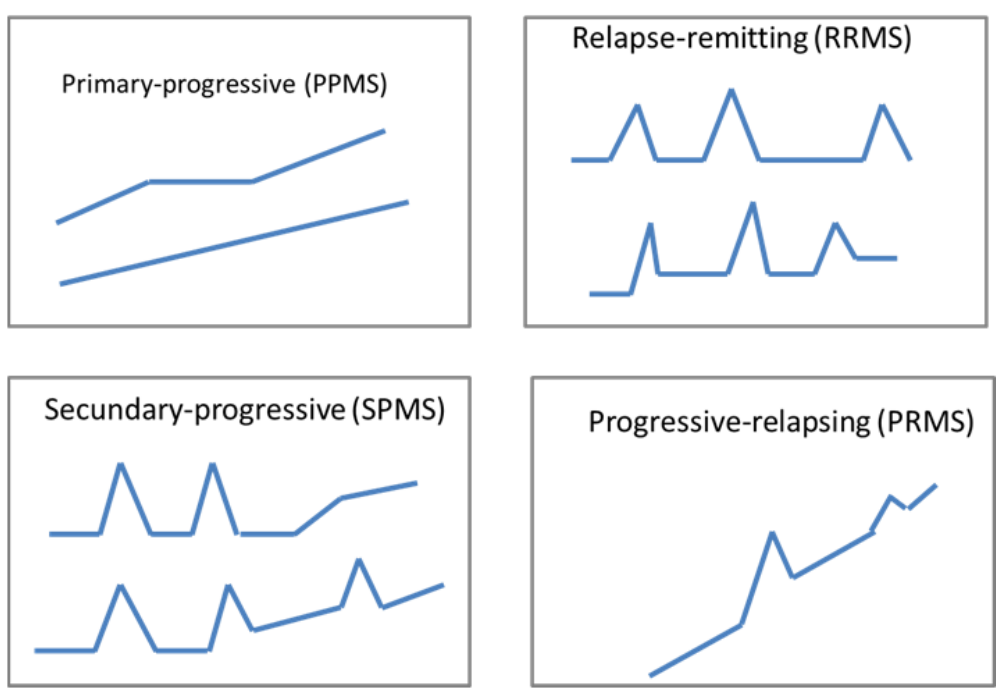

Figure 2: Types of clinical disease progression in MS. Adapted from www.medscape,com/features/slideshow/multiple-sclerosis (30 May 2014)

\subsubsection{Diagnosis}

Multiple sclerosis is a clinical diagnosis. There is no single test that is proof-positive for diagnosing MS. However, there are accepted criteria for making the diagnosis. The 
diagnostic clinical criteria have evolved over time (Tullman, 2013). MS diagnostic criteria used were stablished in 2001 and revised in 2005 and 2010 (Polman et al, 2011). These criteria can be summarised by a matrix that aims to demonstrate four essential points:

-Existence of lesions in the CNS;

-Presence of these lesions in more than one region of the CNS, i.e. its spread in space; -Occurrence at different times, i.e. their dissemination in time;

-Lack of another better explanation for the neurological abnormalities found than the diagnosis of MS (Sá, 2010a).

Thus, the diagnosis of MS requires at least one episode of neurological dysfunction consistent with inflammation and demyelination that occurs in the absence of fever or infection. It must last at least 24 hours and present objective evidence of lesions disseminated in space and time that may be demonstrated clinically or by magnetic resonance imaging (Polman et al, 2011).

An accurate diagnosis of multiple sclerosis is based on the medical history and a neurological exam using various tests. In addition, a variety of specialized procedures are helpful in accurately diagnosing MS. These include imaging techniques, such as MRI, spinal taps or lumbar punctures and examination of the cerebrospinal fluid, evoked potentials to determine if MS has affected a person's nerve pathways, and lab analysis of blood samples. Other possible conditions apart from MS must be excluded.

The introduction of magnetic resonance and its subsequent technological developments have completely changed the diagnostic process in MS. The disease can be diagnosed with greater certainty and early (Barkhof et al, 2003). The RMI helps in the diagnosis of MS because it can show lesions with typical morphology and localization of the disease. At the same time it can show the spread in space and time and helps exclude other possible aetiologies (Pedrosa, 2010a).

The study of cerebrospinal fluid (CSF) in MS allows to show the inflammatory nature of the disease. The parameters studied in the cerebrospinal fluid in patients with MS include: cell count, total protein and evaluation of the barrier blood/CSF, quantitative and qualitative analysis of the humoral response (in MS there is additional lgG synthesis in the subarachnoid space induced inflammation), analysis of markers of inflammation (cytokines, adhesion molecules, metalloproteinases), cell markers, antibodies and nitric oxide, markers of axonal lesion as neurofilamentar protein, actin and tubulin, tau protein, 24S-hidrocolesterol or apoprotein E (Sá, 2010b). 
The search for biological markers in MS has been the subject of intense research but there is no evidence to support the existence of a reliable marker in MS. In this regard it may be more informative the association of several markers that could establish a profile of the disease.

The neurophysiological examination can be important to demonstrate clinically silent lesions, in some cases enabling patients to reclassify. The evoked potential is defined as consecutive modification of brain activity applying a sensory stimulus. Evoked potentials maintained their clinical utility as they can allow detecting lesions that are not apparent on the neurological examination and further demonstrate the axonal or demyelinating nature of these lesions. Mainly, visual evoked potentials are used but also the somatosensory, auditory, and cognitive analysis will also be useful (Alves, 2010)

\subsubsection{Therapeutics}

Although there is no cure for MS, there are some ways of managing the disease. Treatment of MS typically focuses on: 1) treating the relapses, mainly speeding recovery from them, 2) modifying the course of the disease, slowing its progression, and 3) managing symptoms, trying to slow the development of disability.

\section{Treating the relapses}

The treatment of the first manifestation of the disease or a new outbreak is done with corticosteroids at high doses. They reduce the severity and duration of symptoms. However, there are insufficient data to confirm whether there are long-term benefits with the use of corticosteroids. The most common treatment regimen is a three-to-five-day course of intravenous methylprednisolone. High dose oral prednisone may also be used.

Glucocorticoids are powerful immunosuppressants. They have anti-inflammatory effect with a reduction of proinflammatory cytokines and induction of apoptosis of $\mathrm{T}$ cells, at the same time they regulate the permeability of the blood-brain barrier.

Symptoms that may arise associated with the use of intravenous corticosteroids are: abnormal taste, oedema in the lower limbs, distal paresthesias, weight gain, acne, increased tendency to infections, insomnia, emotional disturbances, glycosuria or decompensation of prior diabetes (Pedrosa R, 2010b; National Multiple Sclerosis Society, 2014). 


\section{Disease modulators}

Only in 1993 the first drug for the treatment of MS, interferon beta-1b (Betaferon ${ }^{\circledR}$ ), was approved in the USA. In a randomized trial this drug significantly reduced disease activity in terms of reducing the number of relapses and measures of RM when compared to placebo (Batista et al, 2010). Later, the FDA approved an intramuscular formulation of interferon beta-1a (Avonex $\left.{ }^{\circledR}\right)$ and in 2002 a formulation of subcutaneous interferon beta1a (Rebif $\AA)$ was approved in Europe. Regarding the mechanisms of action of interferon, they are still not completely understood but, in addition to antiviral properties, it has immunomodulatory and antiproliferative activity, important in MS: inhibition of $\mathrm{T}$ lymphocyte proliferation and NK cell activity; regulating the expression of MHC molecules and alteration of cytokine production, among others. There are also evidences that suggest an effect of interferon in the preservation of blood-brain barrier with inhibition of metalloproteinases and reduction of cell migration (Hartrich et al, 2003, Shapiro et al, 2003; Boz et al, 2006).

The most common side effects of treatment with interferon are fever, myalgia and headache. Lymphopenia, leukopenia, neutropenia and elevated liver enzymes may also occur. The occurrence of local reactions at injection is also frequent and in 3-4\% of cases skin necrosis happens. Treatment with interferon is contraindicated in pregnancy and discouraged in breastfeeding (Batista et al, 2010).

Apart from interferon, between 1999 and 2003, glatiramer acetate (GA) (Copaxone ${ }^{\circledR}$ ) appears. According to the most accepted theory, its use would promote Th2 cells response. When these cells are exposed to foreign antigens in the periphery mimicking myelin, they would trigger an immune response characterized by the production of antiinflammatory cytokines and possibly neurotrophic factors that regulate the immune response. Several studies in patients with RRMS showed a significant reduction in the number of relapses without worsening of EDSS disability and a reduction in the number of imaging lesions with few adverse reactions (Johnson et al, 2000; Comi et al, 2001).

Treatment with intravenous human immunoglobulin (IVIG) assumed an important role in some neurological diseases. Among the proposed mechanisms for its activity in MS are: neutralizing autoantibodies against myelin proteins, decreasing production of autoimmune antibodies and blocking of Fc receptors of macrophages, promoting immunoregulation and attenuatiating complement activation (Sorensen, 2003; Kazatchkine and Kaveri, 2001; Rodrigez and Miller, 1994). Reduction in the number of relapses, reduction of 
imaging lesions and an improvement of disability were found in some studies but this trend was not observed in others. The conditions of the studies were not the same, what necessarily interferes in the findings (Batista et al, 2010).

In recent years new molecules are being investigated in order to obtain more effective formulations with administration regimens more convenient and less incidence of adverse effects. Natalizumab is among drugs already approved and available in 2010. It is a monoclonal antibody that interferes with the migration of activated lymphocytes across the blood-brain barrier. Phase 2 and phase 3 assays show the benefits of the drug. Other monoclonal antibodies with promising results include: Alemtuzumab, Rituximab and Daclizumab (Freitas et al, 2010).

Among the new oral therapeutic, Fingolimod $®($ FTY720) is a drug with immunomodulating properties, of daily oral administration, which has a different mechanism of action from classical immunomodulators. After phosphorylation, inhibits sphingosine-1-phosphate, a phospholipid mediator of numerous cellular functions. As a result, circulating lymphocytes are sequestered in lymph nodes with the consequent reduction in periphery and in the CNS recirculation (Kappos et al, 2006). In September of 2010 the drug was approved by FDA as first-line medication for relapsing-remitting MS (Freitas et al, 2010).

As new drugs are being provided, the treatment of MS meets new challenges. The older drugs will be replaced by more recent ones with more specific mechanisms of action and fewer side effects. This will require a better understanding of the pathogenesis of the disease and early diagnosis in order to start treatment in early stages of the disease.

\section{Managing symptoms}

As previously mentioned, the disease modifying therapies in MS are used to reduce the frequency and severity of relapses and to delay progression and disability. But treatment of patients also requires strategies to control the symptoms and to prevent secondary complications and increased disability associated with disease. From the initial to the most advanced stages, the range of potential symptoms is vast and includes fatigue, spasticity, bladder dysfunction, ataxia, cognitive impairment, among others. Therefore, symptomatic treatment should be carefully planned and suitable for each patient. It must take into account that there may be an interaction between the symptoms and that the treatment of a symptom can aggravate other. Any approach must necessarily be multidisciplinary, involving the patient actively and include pharmacological and non-pharmacological therapies. 
Effects of Acupuncture on Gait of Patients with Multiple Sclerosis 


\subsection{Gait in Multiple Sclerosis}

\subsubsection{Definition}

Gait is a complex process involving coordination of multiple systems within the body (central nervous, musculoskeletal and cardiovascular systems). To walk, the nervous system must send signals to control a large number of muscles while simultaneously processing sensory information in order to monitor and refine movements, all this while maintaining an upright stance (Winter, 2009). Taking into account the great number of muscles and neural processes involved, gait variability probably arises from a combination of factors.

Several studies reveal that gait variability is an indicator of walking function and that some characteristics of gait variability are associated with neural control of walking (Stergion et al, 2006). Increases in gait variability have been observed in elderly as well as various neurologically impaired populations such as Parkinson's disease, dementia and multiple sclerosis (Socie and Sosnoff, 2013).

\subsubsection{Assessing walking disability}

Walking disability is a major feature of neurological diseases. Consequently, measure and assess walking disability is important in multidisciplinary teams. In clinical practice, the WHO international classification of functioning (ICF) is often adopted as the underlying framework for assessment of mobility (WHO, 2001). Different impairments end in abnormal or reduced walking. For instance, in multiple sclerosis, impairment such as weakness and spasticity from pyramidal lesions, loss of co-orientation from dorsal column and cerebellar lesions together with visual and cognitive dysfunction and pain can contribute to walking disability (Figure 3 ).

Impaired disability can be also a marker of disease progression and an important outcome measure of treatment and rehabilitation programmes in diseases such as MS and Parkinson's disease (Pearson et al, 2004). 


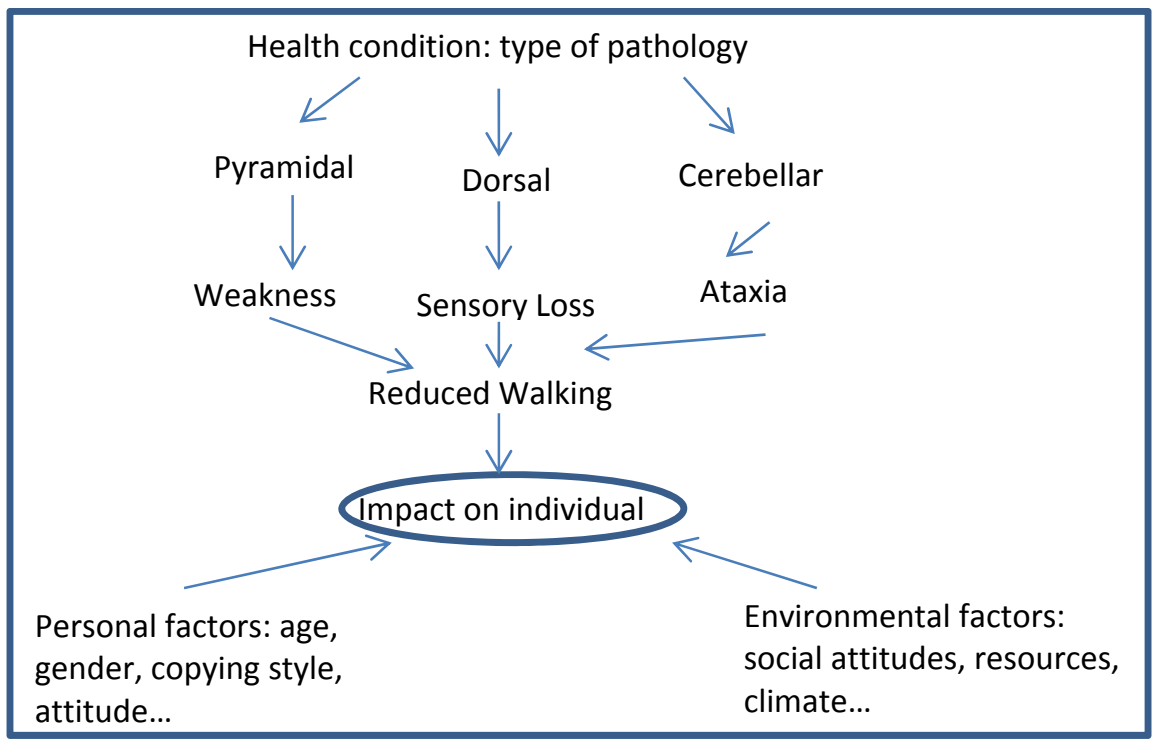

Figure 3: Framework of international classification of function (ICF). Mobility in MS. Adapted from Pearson et al. (2004).

Although assessing gait disability is of great importance in some pathologies, there is no consensus regarding the most appropriate tool for characterization of gait dysfunction (Kieseier and Pozzilli, 2012). According to Fisher et al. (1999) an ideal measure should be widely applicable, clinically meaningful, easy to administer, valid and reliable, provide reproducible results and be responsive to change.

\section{Self-reports}

The simplest way of gait assessment involves patient-reported measures or self-reports. They give the patient's own perspective on the impact of walk impairment in their daily lives. Advantages of self-reports measures are that they are easy to perform and low in cost. The principal disadvantages are that patients can prioritize specific aspects and that their emotional state may be an influence during self-rating (Hobart et al, 2003). The most common of these reports is the Multiple Sclerosis Walking Scale 12 (MSWS-12). This survey consists of 12 questions that assess gait impairment in terms of the speed, distance and daily activities impact perceived by the patient. The MSWS-12 has been validated as a measure of walking function and as responsive to gait changes (Hobart et al, 2003; McGuigan and Hutchinson, 2004) and also as a measure of walking quality metrics (Pilutti et al, 2013). 


\section{Quantitative analysis}

Timing of walking

Timed walking over a fixed distance has been extensively used as a clinical measure of gait in a variety of neurological conditions and form part of a recommended outcome measure for clinical trials in multiple sclerosis (Fisher et al, 1999). The main advantages of timed performance tests are that they are simple, quick and inexpensive, and allow data to be expressed in relation to a normal range, allowing the degree of deviation to be clearly seen. The main problem of these testes is a decrease in the reliability between tests, what lead some researchers to suggest that a range $>20 \%$ is most likely to represent reliable change (Schwid et al, 2002), although this may differ depending on the population studied. The most common of timed performance tests is the 25 -foot walk test (T25FW). In this test, person is directed to walk, as fast and safety as he/she can, across a clear marked linear 25 feet course. There are no turns, start is static and assistive device can be used. Also, 10-metre Timed Walk (10MTW), 30-meter Timed Walk (30MTW) and 100-meter Timed Walk (100MTW) are used. Shorter walking tests (T25FW, 10MTW, 30MTW) represent good measures of overall walking ability and are suited for use in clinical setting (Gijbels et al, 2012).

\section{Endurance tests}

Endurance tests like $2 \mathrm{mWT}$ or $6 \mathrm{mWT}$ ( 2 or 6 minutes walking test, respectively) are used to measure the maximum distance that a person can walk over the time interval. According to Kieseier and Pozzilli (2012), 6mWT and 2mWT tests are good for assessment of walking fatigability, maximal walking distance limitation and functional capacity. In these tests the person is directed to walk for 6 (or 2) minutes at maximal speed, back and forth in a hallway turning at each end. Assistive devices may be used, rest is not permitted and encouragement is not allowed (Gijbels et al, 2011).

\section{Quantitative movement analysis}

The clinical tests described lack in sensitivity in mild gait impairment. To avoid that, it is possible to use specific movement analysis techniques that provide detailed quantification of walking. These techniques include body-worn inertial sensors, instrumented walkways and motion-capture systems, being able to detect differences in spatio-temporal gait parameters. This can lead to detect differences between persons with MS who have mild impairment and healthy controls. The early detection of gait changes could provide an early intervention (Sosnoff et al, 2011a). These advanced movement techniques allow the quantification of gait variability studying parameters like step time, step length or single support time. Some reports have shown a significant difference in gait variability between 
persons with MS and healthy controls (Sosnoff et al, 2012). However, these procedures also have disadvantages: cost, need of laboratory space and processing data.

A significant amount of research has been carried out in order to find a low cost, clinically feasible test that is also sensitive to mild impairment for early detection of gait disability.

\section{Functional scales}

This kind of scales should be sensitive and, therefore, change when the patient has a clinical course in either direction. They should not be subject to variation in different conditions, or carried out by different observers. They must be also easy to apply under different conditions, and useful in all phases of the disease. Ideally, they can be administered by non-specialists, which is also important to maintain a low cost (Weinshenke, 1996).

Many clinical rating scales have been proposed to assess the impact of MS on patients, but only few have been evaluated formally for reliability, validity and responsiveness.

In 1955, the DSS (Disability Severity Scale) was introduced by Kurtzke. The purpose was to create an objective approach to quantify the level of functioning that could be widely used by health care providers diagnosing MS. The scale was modified several times to more accurately reflect the levels of disabilities clinically observed. The scale was renamed the Kurtzke Expanded Disability Status Scale (EDSS). The EDSS (Kurtzke, 1983) was designed as an observing examination scored on an ordinal scale, and was the first one to be widely adopted as an outcome measure in MS (Pearson et al, 2004).

The EDSS provides a total score on a scale that ranges from 0 to 10 . The first levels 1.0 to 4.5 , refer to people with a high degree of ambulatory ability, while the subsequent levels 5.0 to 9.5 , refer to the loss of ambulatory ability. The range of main categories include (0) = normal neurologic exam; to (5) = ambulatory without aid or rest for 200 meters; disability severe enough to impair full daily activities; to $(10)=$ death due to MS (Figure 4). In addition, it also provides eight subscale measurements called Functional System (FS) scores. These subscale categories are listed below. The levels of function within each category refer to the eight functional systems affected by MS: pyramidal (motor functions), cerebellar, brainstem, sensory, bowel and bladder, visual, mental and other. The total EDSS score is determined by two factors: gait and FS scores. EDSS scores below 4.0 are determined by the FS scores alone. People with EDSS scores of 4.0 and above have 
some degree of gait impairment. Scores between 4.0 and 9.5 are determined by both gait abilities and the FS scores.

(http://www.va.gov/MS/Professionals/Diagnosis/Kurtzke_Expanded_Disability_Status_Scale.asp) (15 June 2014)

The EDSS is widely used and accepted as a valid tool to clinically measure and evaluate MS patients' level of functioning. The main problem of the EDSS scale is that it is ordinal. This scale cannot be used for parametric statistical comparisons, which disempowers the studies using this scale as a measure (Izquierdo and Ruiz-Peña, 2003).

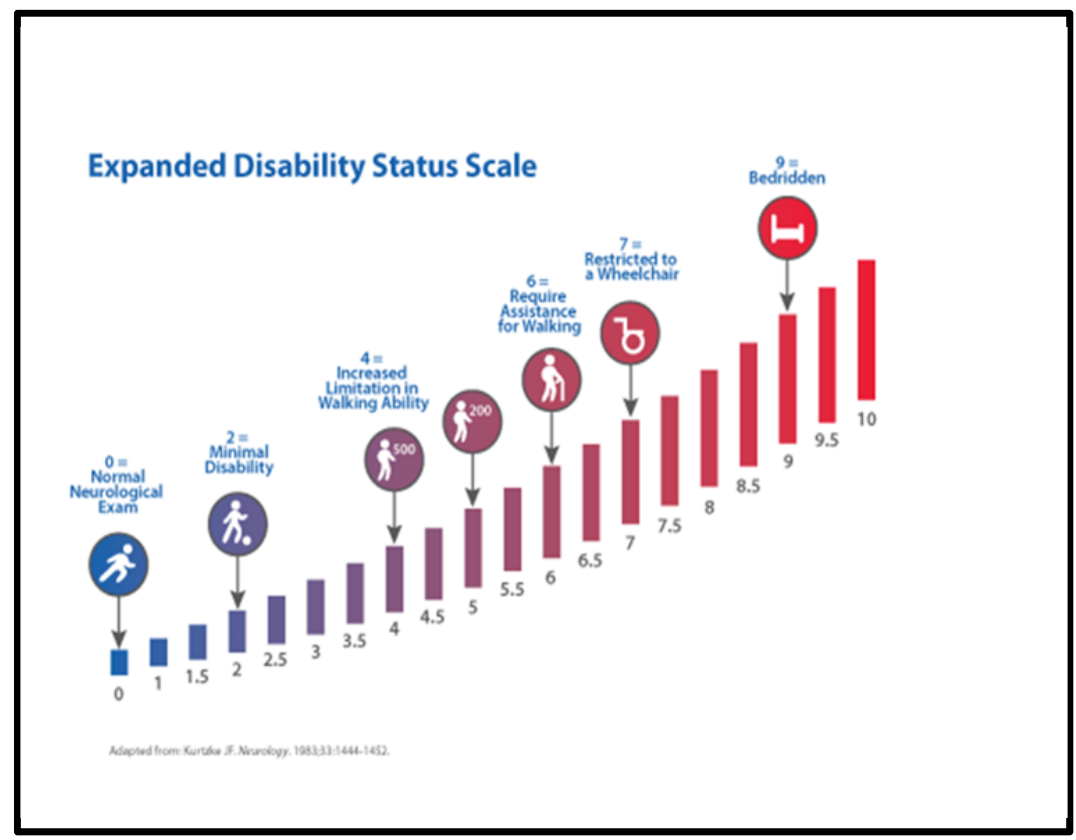

Figure 4: Schematic representation of the Expanded Disability Status Scale. Taken from: http://mobilitymattersinms.ca/YourMobility/AssessmentTests (15 June 2014)

\subsubsection{Gait impairment in MS}

Gait dysfunction represents one of the most debilitating symptoms experienced by MS patients. $85 \%$ of individuals with MS report gait impairment as a major limitation of their lives. The majority of persons with walking difficulties also indicate activity restriction $(80 \%)$, effects on emotional health $(70 \%)$ and increased concern falling and other safety issues (70\%) (LaRocca, 2011).

Gait impairment in MS is believed to be multifactorial, linked to leg strength, spasticity, aerobic capacity and fatigue. There are increasing evidences that cognitive functions are also involved (Sandroff et al, 2013; Thoumie et al, 2005; Kelleher et al, 2010; Sosnoff et al, 2011b). It was proposed that an increase in gait variability results from an increase in fatigue in MS (Socie and Sosnoff, 2013). 
Gait impairment is also important for indexing disease progression and rehabilitation in MS. The EDSS relies heavily on patient's ability to walk. To date, the majority of research focusing on gait dysfunction in persons with MS has focused on clinical assessments (Gijbels et al, 2012) and average spatiotemporal parameters. Performance walking tests such as the timed 25-foot walk, 2-minute walk, and 6-minute walk are commonly used to measure gait function in MS and routinely demonstrate that persons with MS walk slower than healthy controls. Analysis of spatiotemporal parameters have revealed that individuals with MS walk slower, taking shorter, slower steps, and spending more of their gait cycle in double-support than healthy controls (Sosnoff et al 2011b). Deficits in gait have been observed in persons with MS compared to controls even at fixed walking speeds (Spain et al, 2012). Difference in performance was greatest in those with the highest amount of clinical disability (Goldman et al, 2008).

At this moment the main rehabilitation options for gait impairment is pharmacological treatment of symptoms and physical rehabilitation. Pharmacological treatment target specific symptoms that have influence in gait. For instance, drugs that act to improve nerve conduction can improve walking speed in some cases but adverse side effects and cost are great disadvantages. On the other hand, exercise training can help to mitigate and restore some of the declines in walking function associated with the progression of disability in MS (Snook and Molt, 2009).

Beyond the positive effect of exercise on walking function shown in general for a range of disability levels in MS, research using advanced motion techniques gave evidences that there are changes in kinematics of gait even in the absence of clinical disability in patients of MS. These early gait changes reveal the importance of understanding the possible beneficial effect of gait therapies in persons with MS showing minimal walking impairment (Martin et al, 2006). 


\subsection{Traditional Chinese Medicine (TCM)}

\subsubsection{Overview of TCM}

From the earliest times man tried to fight against disease and pain. One of the oldest therapeutic systems used by mankind for health and wellbeing is the Traditional Chinese Medicine (TCM). The origin of Traditional Chinese Medicine is uncertain but archaeological findings indicate that it has more than 5000 years. There have been found therapeutic instruments used between 4000 and 6000 years ago (Hempen and Chow, 2006). At these early times not only stone needles, but also bamboo splinters, were used. Later, metal medical needles made of bronze, iron, gold, and silver began to be used.

Over the centuries there is abundant literature related to the general practice of TCM. The oldest medical manual "Huangdi Neijing" (The Yellow Emperor's Inner Classic) was written more than 2300 years ago. In this book it was established therapeutic treatment for the first time in the practice of Chinese Medicine. The first classical work "Zhenjiu Jiayi Jing" (The Systematic Classic of Acupuncture and Moxibustion) by Huang-Fu Mi, dates from 215-218 AC, and provides, for the first time, a clear terminology, a careful topological description of individual acupuncture points and a systematic indication of their effects (Hempen and Chow, 2006). The first official TCM school, the Imperial Medical School (Tai Yi Shu), was founded in China in $624 \mathrm{AC}$. In the following centuries several textbooks were produced and had great importance to spread knowledge at that time. Later, in 1601, "Zhenjiu Dacheng" (Great Compendium of Acupuncture and Moxibustion) was published by Yang Jizhou in which the theory underlying the whole of Chinese Medicine was presented. For the past 50 years, several hundreds of textbooks and monographs on TCM have been published. According to the WHO, today, a sophisticated body of knowledge was built over centuries, including basic theory, diagnostic procedures and treatment approaches that are now available (WHO, 1996).

From the third century to the end of the nineteenth century new developments took place in TCM, for instance, the number of acupuncture points used for treating various diseases greatly increased. Since the establishment of the People's Republic of China, policies for TCM were implemented in China (Xia et al, 2010). Nowadays, higher education is available in a substantial number of TCM universities, medical universities and faculties all over the world (Santos, 2012).

TCM doctors soon perceived that the human being is a living being integrated in an environment that influences him. Thus, concepts used to explain nature, such as Yin/Yang 
and Five Elements, became central to TCM theory. The goal of the clinician in TCM is to maintain the body in a harmonious balance, both internally and in relation to the external environment (Santos, 2012). To reach this aim, TCM can use different tools including: Chinese pharmacology (phytotherapy), Qigong (biofeedback neurovegetative exercises), dietetics, Chinese manual therapy (Tuina), and acupuncture.

The concept of Yin-Yang is the basic concept of all the oriental sciences. It matches the precondition for the origin of all natural phenomena. The ancient Chinese civilization realized that opposites are not belonging to different categories, but rather two sides of the same reality. There is a dynamic equilibrium in which opposites are interdependent, which means that reality is seen as a manifestation of the interplay between opposites. These opposites are called Yin and Yang. Yin and Yang are the expression of duality, and the strength matrix of a cyclic motion interpolation (Cerqueira, 2004). The Yin-Yang balance is primordial in all vital processes of adaptation of the living beings and their environment (Nguyen, 2011).

As ancient Chinese doctors went through the understanding about the material world, the Theory of the five elements was formed, describing the characteristics of these elements and their relationships, including their activities and changes. The Theory of the five elements holds that nature is constituted by five substances: wood, fire, earth, metal and water. The development and changes in anything or phenomenon are the results of continuous movement, intergeneration, and inter-inhibition (inter-dominance) of these five elements. In Traditional Chinese Medicine, this theory applies mainly to explain the pathophysiological features of all internal organs and tissues of the human body, pathophysiological relationships between them and the relationship between human body and the changing environment, in order to provide guidance in diagnosis and treatment (Ping, 2002).

Ancient Chinese doctors linked in a logic way the physiology and pathology of the Zang$F u$ (viscera and organs) and tissues of the human body with environmental factors that has to do with life of humanity. Organs and body tissues are classified into five categories, taking the five elements as a base, and according to their different properties, functions and shapes, in order to use as a reference for observing internal relationships and their movements (Ping, 2002).

According to TCM theories, diseases were cured mainly by means of adjusting the relationship between Yin and Yang, promoting the communication between the channels 
and collaterals (conduits), regulating the vital energy (Qi) and blood (Xue), reinforcing positive factors, and eliminating negative ones (Agents) (Xia et al, 2010).

\subsubsection{The Heidelberg Model of TCM}

The Heidelberg Model of TCM was developed by Prof. Johannes Greten supported by the pioneering works of the medical-sinologist Prof. Manfred Porket, thus adopting a Latin terminology, and by the Leibniz' analysis of the I Ging ("The Book of Changes"). In this model, the central postulates of Chinese Medicine are recompiled and explained as a logical model of system biology, based on a mathematical language (Greten, 2007). This model unifies the contemporary medical-scientific knowledge with the concepts of different schools of Chinese medicine. It sees Chinese medicine as a novel vegetative medicine. Greten (2010) defined TCM as "a system of sensations and findings designed to establish a functional vegetative state".

\section{Important concepts}

Chinese medicine is based mainly on a system that describes functional abnormalities by the sensations (signs and symptoms) felt in a specific way by the patient, and these symptoms come from specific dysfunctions. In a state of health, there is a harmonious balance between Yin (structure, substance) and Yang (function), a balance between ascending and descending vectors of human regulation (homeostasis). In this context, Yang represents the driving force for activities and warmth. Yin represents deep rest, cold, dampness and nourishing the tissue. We can find such paired Yin-Yang, at different levels in human body: Kinases (Yang) and phosphatases (Yin); the pro-oxidants and antioxidants in lipoproteins, to give some examples (Santos, 2012).

One of the fundamental concepts in TCM is $Q i$, usually translated by energy, vital force or vital energy. It is the foundation of everything and the immaterial force that promotes the activity of the organisms. According to the Heidelberg model of TCM Qi is defined as "vegetative functional capacity of tissues and organs that can cause a sensation of pressure, tearing or flow" (Greten 2010). When Qi is strong and balanced, there is health, if it is weak, or move in the wrong direction, there is pathology. Thus, the correct movement of $Q i$ is the base for the movement of Xue, for transformation of Jing, the correct movement of body fluids, digestion and adsorption of food, hydration of the organism and resistance to pathogenic factors.

According to Heidelberg model of TCM we can define Xue and Jing as follows: 
- $\quad$ Xue refers to a "form of functional capacity bound to body fluids with functions such as warming, moisturizing, creating Qi and nitrifying a tissue". From a western point of view the clinical effects of Xue can be compared to the effect of microcirculation, including blood cells, plasmatic factors, endothelium and parenchyma.

- Jing refers to the "structure potential that includes the functional repertoire of a cell via the DNA and at the same time reproductive functions".

In TCM, understanding the concept of Shen (that can be compared to certain higher brain functions in western medicine) is also fundamental. Greten (2010) define Shen as "functional capacity to put order into mental associativity and emotions, thus creating mental presence". The functional state of Shen is evaluated by signs as the coherence of speech, the gloss of eyes and fluent fine motoric (control of motor functions).

\section{Phases and orbs}

In the scientific approach of the Heidelberg model of TCM, phase is a central concept. "Phase is a regulatory term, part of a circular process that, when referring to men, expresses a vegetative functional tendency, and which manifestation is defined as an orb" (Greten 2010). There are five phases: wood, fire, earth, metal, water. To each phase corresponds a vector. The phases present a cyclic pattern that can be represented as a sinusoid curve around of target-values (Figure 5). Each phase is represented by two orbs, one with Yin characteristics and another with Yang, with the exception of the Fire phase that has four orbs (Greten 2010). In total there are twelve orbs: Hepatic, Felleal, Cardiac, Tenuintestinal, Pericardial, Tricaloric, Stomach, Lienal, Pulmonary, Crassintestinal, Renal and Vesical.

According to cybernetics (regulatory processes), periodic fluctuations of regulation happens around a target value, activating or de-activating mechanisms responsible for body transformations. This regulation process is expressed at different vegetative functional states and follows a sinusoidal curve (Seca, 2011). As can be seen in the Figure 5, Yang phases (wood and fire) are regulated mainly by sympathetic system, while in Yin phases (metal and water) parasympathetic activity is predominant. 


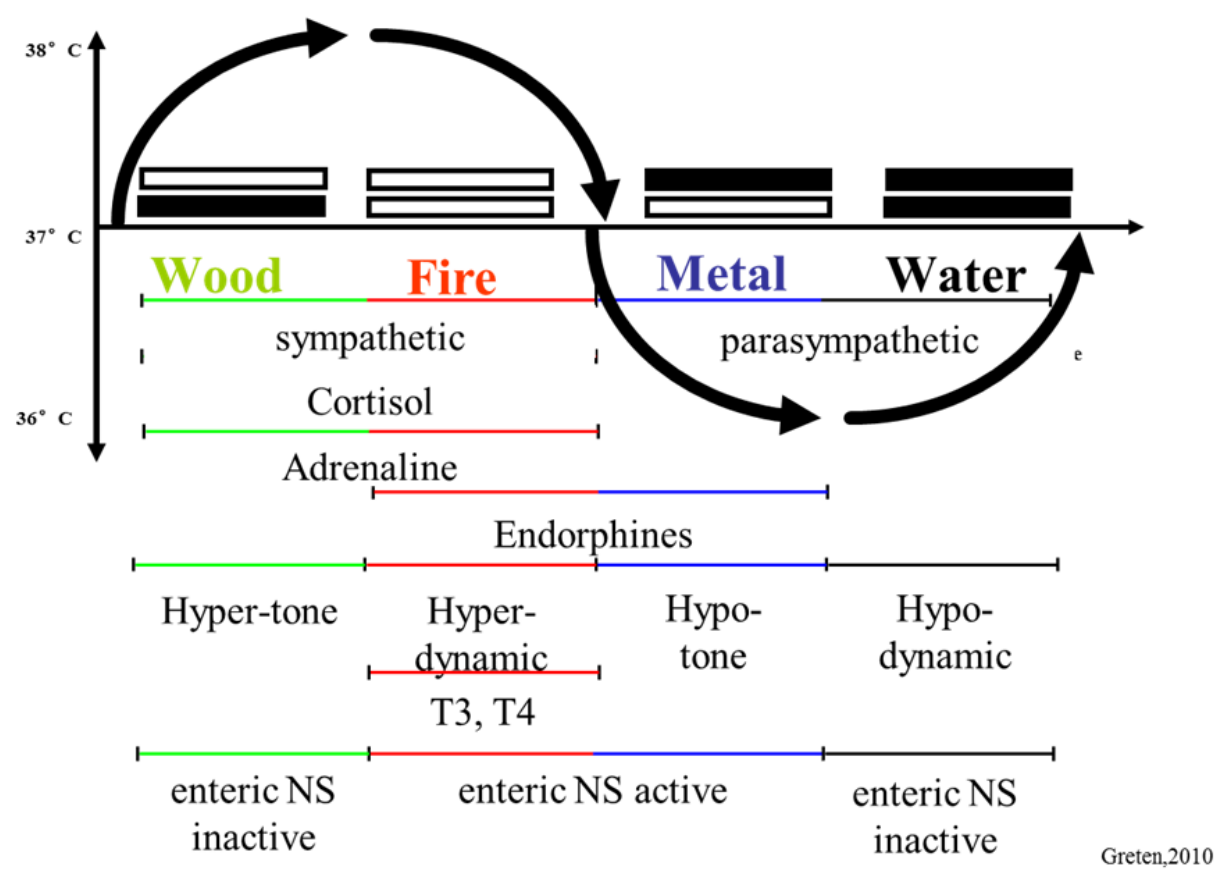

Figure 5: Phases Wood, Fire, Metal, Water according to the functional vegetative state of the organism and its manifestations. Taken from Greten (2010).

Our body is continuously exposed to daily interactions with the environment. But sometimes the vegetative tendency becomes more intense and then manifestations of this tendency appear. When this happens, the continuum of regulation is disrupted and pathological manifestation happen. Thus, there are two functional states: the continuum, in which the functional manifestations of vegetative tendency disappear during the homeostatic process, and the state of dominance of a signal which becomes a critical symptom (Greten, 2010).

\section{Mechanisms of pathogenesis}

According to the Heidelberg model of TCM, there are four principal mechanisms of pathogenesis:

- Deficient transition - The vegetative tendencies, the phases, should be clearly transformed one into another, so that the equilibrium remains constant. Occasionally, there is a lack of functional capacity of transformation in the body. The power of transformation of a vector into another, within the circular function, is blocked, stopping the cycle of regulation and resulting in pathological signs (Santos, 2012)

- Imbalance agonist/antagonist - When there is an imbalance of agonists or agonists and antagonists, one of the phases will be in excess, leading to signals of the phase in excess (Greten, 2010). 
- $\quad$ Excess of an agent - If an agent is continuously present, the phase with which it is related is also continuously produced, leading to an increase of the respective vector. (Seca, 2011)

- Yin deficiency - The regulation model of the body can be compared to a thermodynamic system. Thus, when a structure with less matter is subject to variations it will manifest a more unstable variation curve, leading to higher peaks of the variable, nevertheless, the turning point will be achieved faster. In terms of TCM, lack of Yin means lack of substance (matter) this is why Yin deficiency causes an extreme course of the curve of regulation. It leads to labile Qi.

There are four types of yin deficiency: lack of functional tissue (yin deficiency "sui generis"); lack of body fluids; lack of microcirculation within the tissue (lack of Xue); functional deficits at the cellular level (lack of Jing) (Greten, 2010)

\section{Diagnostic}

The differential diagnostic in TCM results from the collection of relevant data gathered by different tools of evaluation of the patient:

1-Observation of the body shape, of parts of the body (skin, face, lips, tongue and mucosa), actions and movements, tone of voice, caught, breathing and smell.

2-Querying about: clinical history, pass disturbances, habits, food habits and appetite, temperature sensation, type and location of pain.

3-Palpation of skin, members, hands, thorax, abdomen and acupoints.

The Heidelberg model shows that TCM diagnosis can be regarded as the vegetative state of the body, which can be defined by key symptoms. Thus, to establish a TCM diagnostic four steps are necessary (Figure 6):

1-The first step will be the analysis of patient's constitution. From the constitution the patient's inner nature can be verified, that means his/her tendency of action-reaction, based on his/her phenotype and in his/her body language/communication.

2-The second step will be to investigate the agent involved in the pathogenic process. An agent or pathogenic factor is regarded as a functional power that causes changes in the functional properties of the individual and produces its own clinical signs, inducing diagnostic relevant signs (orbs). The agent can be classified as external, (ventus, algor, ariditas, aestus, ardor), internal (ira, voluptas, maeror, timor, pavor, solicitude, cogitacio) and neutral (bad nutrition, accidents, among others).

3-The affected orb will indicate the functional state of a body region, which correlates with the functional properties of a conduit (Greten 2010). 


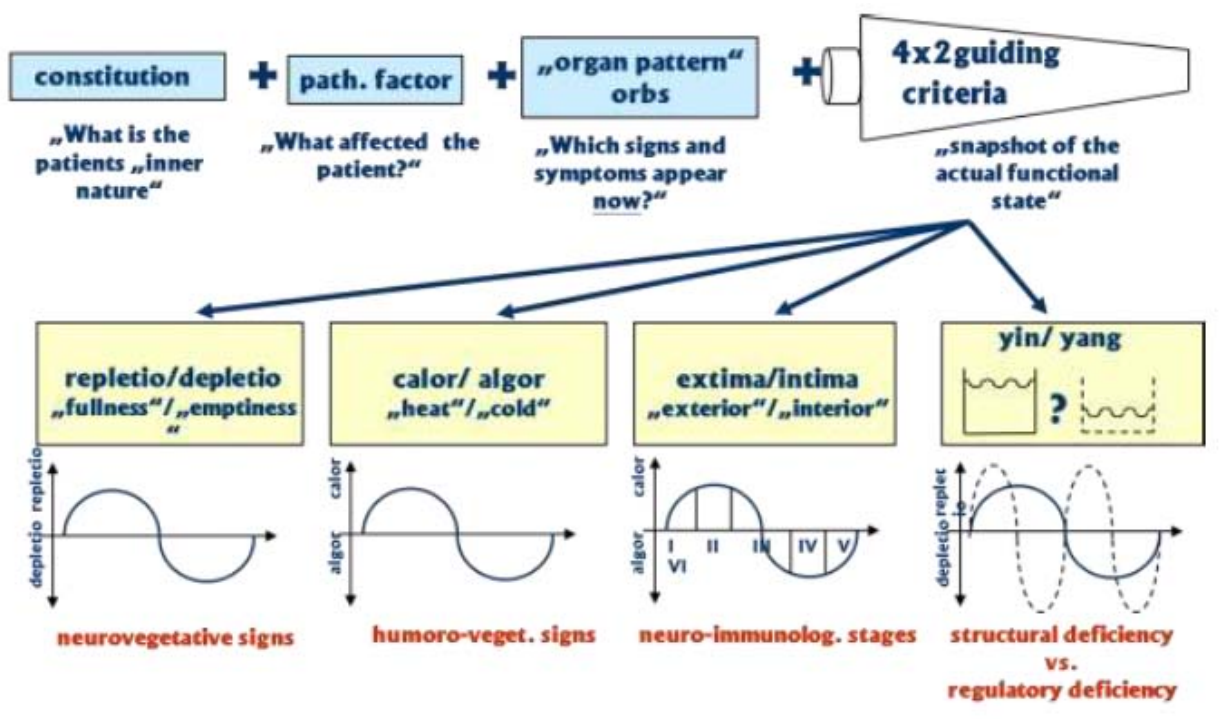

Figure 6: Schematic representation of the components of functional diagnosis in TCM according to Heidelberg model. Taken from Greten (2010).

4-The fourth step will be to analyse the four guiding criteria. These guiding criteria are an interpretative approach of body regulation, according to the Heidelberg Model of TCM. The body regulation is observed at four different levels:

- $\quad$ Neurovegetative level (repletion/depletion). In general, signs of repletion indicate too much Qi, an excess of vegetative stimulation. Signs of depletion indicate lack of Qi, a lack of activation, an excess of de-activation;

- Humorovegetative level (Calor/Algor). Calor means over activation of Xue (microcirculation) and algor means lack of signs of functional microcirculation;

- Neuroimmunlogical level (exterior/interior). Evaluates the level of achievement of the effects of an exterior agent when it invades the body. The most common pathophysiological model underlying this mechanism is the model of six stages of Zhang Zhongjing, called Shang Han Lun ("Algor Leading Theory" or ALT).

- $\quad$ Structural, cellular level (Yin/Yang). This criterion allows distinguishing whether the symptoms/signs correspond to a primary dysregulation, a functional dysregulation (Yang) or if these symptoms represent a secondary dysregulation, a structural deficit, a deficit in functional tissue (Yin).

The ALT model (Figure 7) referred before is based on the idea that the agent invades from the exterior to the interior (from the extima to intima), thereby overcoming the defence levels, affecting the flow of $Q i$ and Xue. It constitutes a specific approach of interpretation of the $3^{\text {rd }}$ guiding-criteria: extima/intima, as stages I to III are extima (Yang) and stages IV to VI are intima (Yin). 
- When the external agent algor (cold) invades the skin, the first defensive layer is affected: the defensive $Q i$, and may induce a localised de-activation of Xue, in western terms, a regional lack of microcirculation. As the body is unable to warm that specific region, it reacts producing reactive calor to warm the conduits and extima in order to expel the invading agent. Thus, algor may affect primarily the conduits that contain more Xue than Qi: the Vesical and Tenuintestinal conduits - ALT Stage I (Yang major)

- If this attempt to expel algor fails, the agent continues the invasion. The flow of Qi is blocked more easily than of Xue, as "Qi moves the Xue", so the phases and orbs more prone to this affection are the ones more dependent on Qi, Stomach and CrassIntestinal. The production of reactive calor reaches the highest point (Spendor Yang) - ALT Stage II.

- If the agent continues the invasion, it overcomes the flow of Xue within the conduits, it may lead to a reverse flow of Xue into the interior, with a relative lack of reactive heat. Frequently, Xue from the inside will be mobilized against the agent causing sensation of internal heat. It may be said that the agent algor and the flow of Xue within the conduit drives each other in and out repeatedly - ALT Stage III (Yang Minor). As this stage occurs still on the extima, and the mobilization of internal heat is a feature of the phase wood, it affects the Felleal and Tricaloric conduits, as there are symptoms and signs of "imbalanced distribution" of energies.

- $\quad$ On the Stage IV (Yin major), the calor is overwhelmed and the algor invades the interior: the guiding-criteria algor is present. When algor affects the Qi of the body islands, the orbs affected are those more sensitive to diminished activity of Qi, the Lienal and Pulmonary orbs.

- When algor affects the Xue of the body island, orb functions depending on Xue are more easily affected, the Hepatic and Pericardial orbs - Stage V (Yin flectens). When algor affect the body island $X u e$, it represents the lowest point of energy in which reactivity has totally vanished, and is called the "flat-down" phase, a breakdown of orthopathy. Stage $V$ is decisive for the survival of the individual.

- If Yin and Xue are still available, then is possible to warm up slowly towards Stage VI (Yin minor). In Stage VI the hypofunctional Yin state has an upward direction comparable to the phase of water (regeneration) in the model of phases, having the capacity to regenerate. At this stage Cardiac and Renal orbs are involved. 


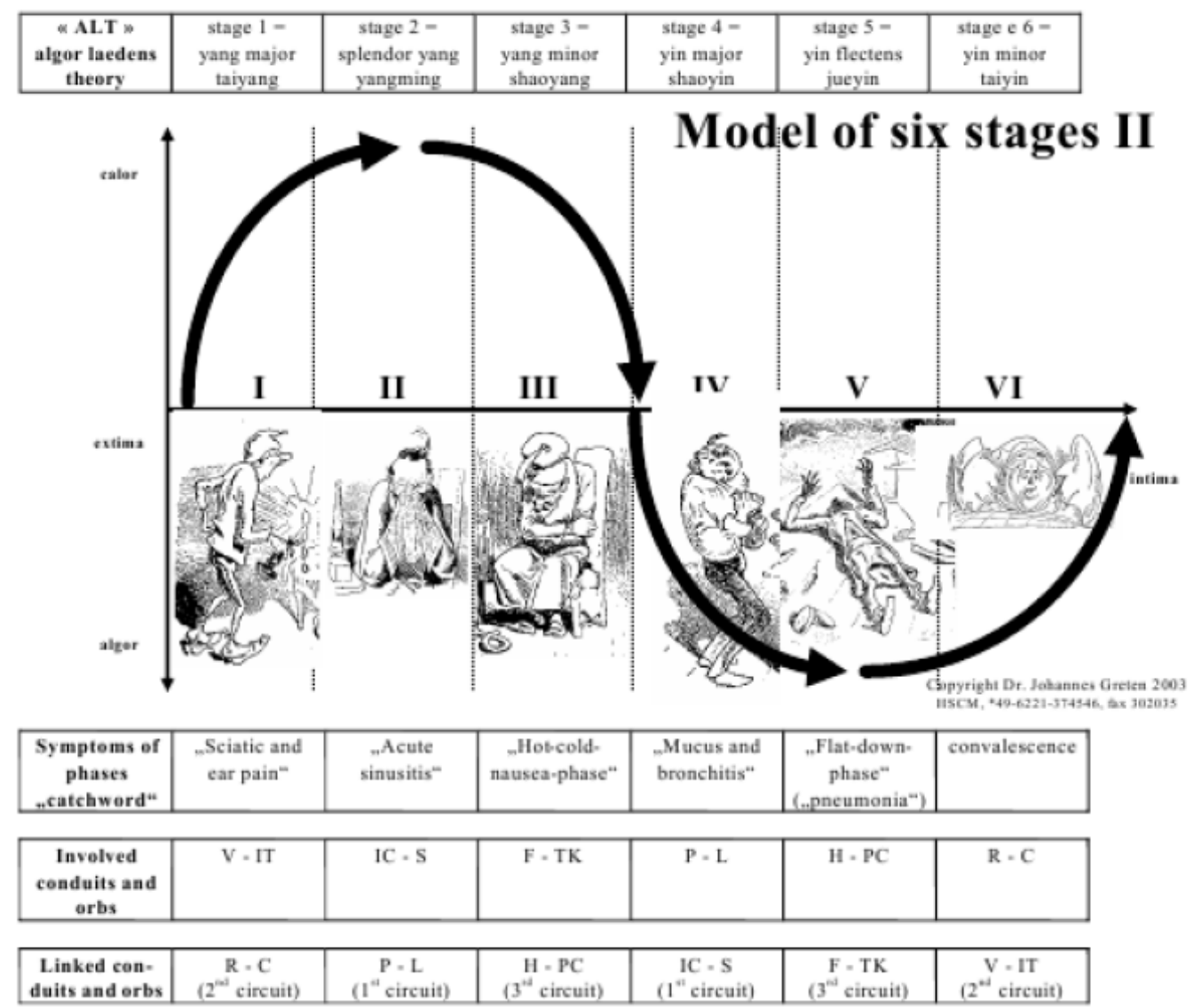

Figure 7: The ALT model. Taken from Greten (2010)

\subsubsection{Acupuncture}

Acupuncture is an important component procedure in TCM which prevents and treats a disease by puncturing certain points of the body with needles. Traditionally, acupoints are defined as the sites through which the Qi and Zang-fu organs (horreales-aulici in the Heidelberg model) are transported to the body surface (Lu et al, 1990). Much of the theory accepted today was first recorded in the Middle and Late Zhou dynasties. The recorded history of acupuncture starts from about $1520 \mathrm{BC}$ and comes nearly to an end in 1911. It is useful to remind this long history and vast wealth of empirical evidence of acupuncture (Hopwood and Donnellan, 2010).

The Consensus Development Conference (CDC) on Acupuncture held by the National Institute of Health (NIH) in 1998 evaluated the scientific and medical data on the uses, risks, and benefits of acupuncture procedures for a variety of conditions. The statement of $C D C$ on Acupuncture suggested that acupuncture is effective for several diseases and that further research is likely to uncover additional areas where acupuncture interventions will be useful. Also, it is important to point out that according to several authors, one of the 
advantages of acupuncture is that the occurrence of adverse side effects is very low (Xia et al, 2010).

Also the WHO (2002) has issued statements confirming the usefulness of acupuncture in the treatment of a wide variety of conditions. Currently, the practice of acupuncture is spread over 160 countries and regions. According to the World Health Organization the diseases or disorders for which acupuncture therapy has been tested in controlled clinical trials reported in the literature can be classified into four categories as shown below (Table 1)

Table 1: Classification of diseases according to acupuncture clinical trials of literature

\begin{tabular}{|c|c|}
\hline $\begin{array}{l}\text { 1. Diseases, symptoms or } \\
\text { conditions for which } \\
\text { acupuncture has been proved- } \\
\text { through controlled trials-to be } \\
\text { an effective treatment }\end{array}$ & $\begin{array}{l}\text { Adverse reactions to radiotherapy and/or chemotherapy; Allergicrhinitis (including hay fever); Biliary } \\
\text { colic; Depression; Dys entery, Dysmenorrhoea; ERigastralgia,; Facial pain (induding craniomandibular } \\
\text { disorders); Headache; Hypertension, essential; Hypotension primary; Induction of labour; Knee pain; } \\
\text { Leukopenia; Low back pain; Malposition of fetus; Moming sickness; Nausea and vomiting; Neck pain } \\
\text { Pain in dentistry (including dental pain and temporomandibular dysfunction); Periarthritis. of shoulder; } \\
\text { Postoperative pain; Renal colic; Rheumatoid arthritis; Sciatica; Sprain; Stroke; Tennis elbow }\end{array}$ \\
\hline $\begin{array}{l}\text { 2. Diseases, symptoms or } \\
\text { conditions for which the } \\
\text { therapeutic effect of } \\
\text { acupuncture has been shown } \\
\text { but for which further proof is } \\
\text { needed }\end{array}$ & 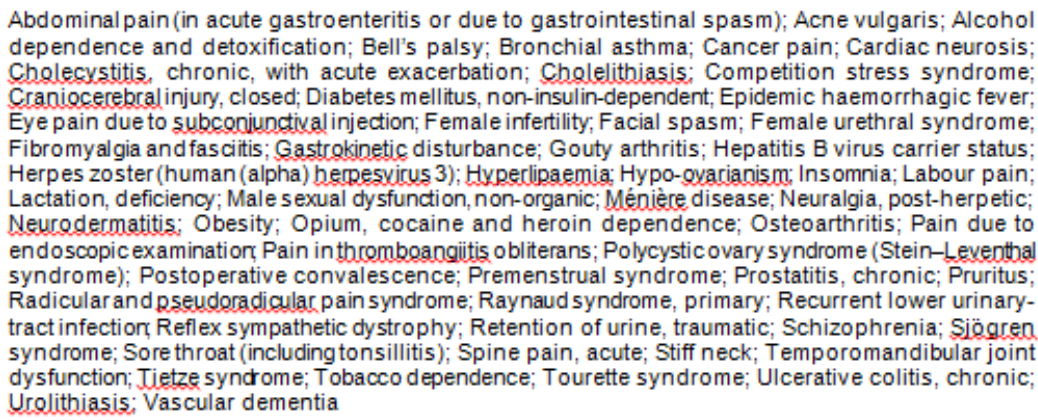 \\
\hline $\begin{array}{l}\text { 3. Diseases, symptoms or } \\
\text { conditions for which there are } \\
\text { only individual controlled trials } \\
\text { reporting some therapeutic } \\
\text { effects, but for which } \\
\text { acupuncture is worth trying } \\
\text { because treatment by } \\
\text { conventional and other } \\
\text { therapies is difficult }\end{array}$ & $\begin{array}{l}\text { Chloasma; Choroidopatby, central serous; Colour blindness; Deafness; Hypophenia; Irritable colon } \\
\text { syndrome; Neuropathic bladder in spinal cord injury; Pulmonary heart disease, chronic; Small airway } \\
\text { obstruction }\end{array}$ \\
\hline $\begin{array}{l}\text { 4. Diseases, symptoms or } \\
\text { conditions for which } \\
\text { acupuncture may be tried } \\
\text { provided the practitioner has } \\
\text { special modern medical } \\
\text { knowledge and adequate } \\
\text { monitoring equipment }\end{array}$ & $\begin{array}{l}\text { Breathlessness in chronic obstructive pulmonary dis ease; Coma; Convulsions in infants; Coronary heart } \\
\text { disease (angina pectoris; Diarnhoea in infants and young children; Encephalitis, viral, in children, late } \\
\text { stage; Paralysis, progressive bulbar and pseudobulbar. }\end{array}$ \\
\hline
\end{tabular}

Several studies in neurophysiology concluded that acupuncture has the main function to mediate the body homeostasis, acting mainly in the balance of autonomic, neurochemical and humoral functions. Findings from basic research have begun to elucidate the mechanisms of action of acupuncture $(\mathrm{NIH}, 1998)$. It is now accepted that three general mechanisms can explain this action: energetic, neural and humoral mechanisms (Figure 8). 


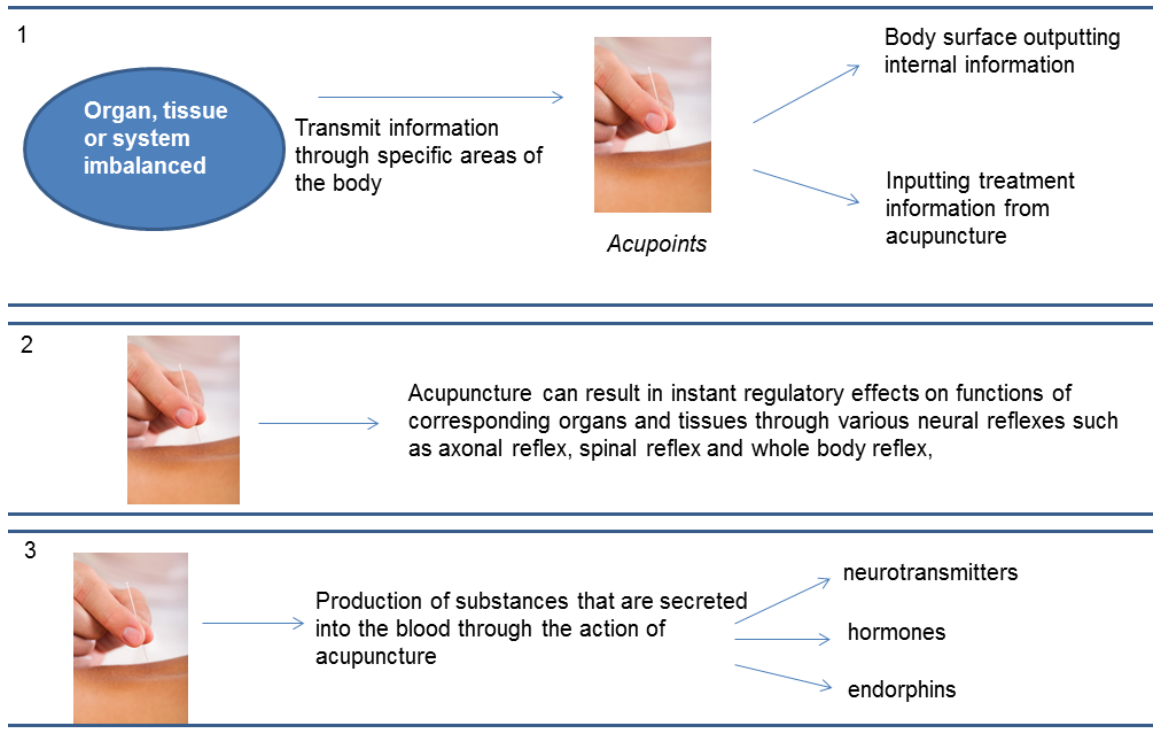

Figure 8: Proposed mechanisms of action of acupuncture. 1-Energetic, 2-Neural, 3-Humoral mechanisms

\section{1-Energetic mechanism:}

A growing number of scientists see the TCM as a cybernetic (regulatory) model. In terms of cybernetic, the conduits (sometimes also called meridians) are information pathways that connect the whole body: upper with lower parts, left with right, interior with exterior and all of them together. The conduits would represent the relationship among various parts of the body. We know now that the human body has multiple levels of neural networks that transmit information of different kinds. When an organ, tissue or system becomes imbalanced, information of these disorders are transmitted through specific areas of the body. These areas are reflex points (acupoint) or information zones. To the physiologist Guan Yuan, an acupoint is actually the location on the body surface outputting internal information and inputting treatment information from acupuncture (Guan-Yuan, 2006; Porket and Hempen, 1995).

Several studies reveal also a relationship between the conduits and the nervous system, blood vessels and lymphatic vessels. The morphological observation of 324 acupoints revealed that 323 have innervation of cranial and spinal nerves; 304 are related to superficial cutaneous nerves, 155 with deeper nerves and 137 with deeper and superficial nerves. Similarly, the acupuncture points and the nerves of its correlated organs belong to the same spinal segment or to the interior of the same nerves segment to which the organ belongs (Guan-Yuan, 2006).

With respect to blood vessels, among 309 points, 24 are on top of an artery, while 262 are adjacent to an artery. Besides, from the location of acupuncture points we can see that 
the conduits are closely associated with blood vessels. The arterial vascularization in the area of acupuncture points has certain ways - regular convergences, irradiation or less regular arrangements. For those who have regular arrangements, the points are located frequently in the centre of such arrangements. (Qiu Mao, 2001).

Some research has found that the conduits are also related to lymphatic plexus or to lymphatics vessels and lymph nodes. Pulmonal, Stomach, Cardiac and Lienal conduits, are found almost entirely in vascularization of lymphatic vessels, adapting deeply or superficially to their corresponding distribution (Qui Mao, 2001).

\section{2-Neural mechanism}

Through various neural reflexes such as axonal reflex and spinal reflex, acupuncture can result in instant regulatory effects on functions of corresponding organs and tissues. For instance, the excretion of bladder, movement of the rectum and instant contraction of blood vessels and other reactions could be induced in this way (Guan-Yuan, 2006).

\section{3-Humoral mechanism}

It refers to the production of substances that are secreted into the blood through the action of acupuncture, like hormones. This mechanism can be further divided into two ways. The first is that acupuncture acts on related organs directly through effects on factors secretion. The second is that acupuncture acts on target organs through the feedback control of secretion. These factors include endogenous opiate-like substances and many neurotransmitters such as: serotonine, acetylcholine, non-epinephrine, dopamine, among others; and include hormones like prolactin, growth hormone $(\mathrm{GH})$, thyroid-stimulating hormone, (TSH) and cortisol. Among the humoral factors, endorphins or enkephalins, are the most significant (Guan-Yuan, 2006; Santos, 2012).

Neural and humoral mechanisms are associated during regulatory process of acupuncture. Sometimes neural factors are primary to humoral factors, but sometimes it is in the other way round.

The increasing importance of acupuncture in recent years as a form of therapy, and the interest of introducing it into primary health care, requires that national health authorities must ensure safety and competence in its use. This means that training in acupuncture should be extended at college level, and suitable mechanisms for supervision of its practitioners have to be created (WHO, 2010). 


\subsubsection{Multiple sclerosis according to TCM}

The most commonly adopted TCM staging for MS was originated by British acupuncturists Blackwell and MacPherson (1993) and offers a logical framework for treatment.

According to Traditional Chinese Medicine, MS can be considered as four stages (Hopwood and Donnellan, 2010):

- The first stage is remission, either before the disease process has really started or, far more likely, as an interval where symptoms recede and a near normal state is regained.

- In the second stage conduit symptoms predominate and the patient aware of sensory or minor motor changes. This indicates a progression of the disease and the symptoms may now include numbness in the lower limbs with accompanying weakness, slackness of joints and gravitational oedema. The whole body feels heavy and the legs may feel cold. The joints are often painful. The patient does not react well to heat. Occasionally there is fever. The tongue is greasy with a yellow coat and the pulse is rapid and slippery. As the disease progresses, evidence of Zang Fu organ failure becomes apparent, with the patient now feeling fatigued and often ill. Chinese theory holds that MS is fundamentally an invasion of external agent: "Damp Heat" (Calor and Humor), possibly originally caused by an invasion of "Cold Damp" (Algor and Humor) and this will begin to affect the Stomach, Lienal and Hepatic.

- $\quad$ In TCM terms, in the third stage, the production of Qi and Xue by the Lienal is diminishing, resulting in deficiency. The retention of "Damp" (Humor) in the system weakens the Lienal further, initiating a vicious circle. The symptoms include tiredness, listlessness, flaccidity of muscles and a tendency to fatigue. The patient may have a poor appetite and suffer from bowel problems, in particular loose stools. Blurred vision, always worse when tired, and a pale dull face are also found. There may be muscle stiffness with cramps, spasticity and mild tremor.

- $\quad$ In fourth stage the problem predominantly is Kidney (Yin and Yang) deficiency. Symptoms include severe weakness and fatigue. The patient often appears spiritless and there may be a pale complexion and premature ageing. Muscle weakness and atrophy are likely to be marked. Stiffness and muscle spasm are also common with severe tremor and ataxia. Low back pain is often very distressing. Other symptoms are urinary urgency, incontinence or retention. 


\subsubsection{Heidelberg model of TCM and Multiple sclerosis}

The paraorb of the brain (paraorbis cerebri) refers to signs and symptoms that are related to general functions associated with the brain. It is a paraorb because is considered to be a semi-autonomous group of signs, within the general understanding of the Renal orb. That means that signs of the paraorb (loss of memory, loss of speed of mind and velocity of thinking) occur in the phase Water (Renal orb).

In the system of the phases, neurological functions are also related to the Cardial orb (phase Fire), as this is the counterpart of the Renal orb. The neurological term referring to Cardial function is Shen (the ability and the power to create coherence of perception, coherence of speech, fluent fine motorics) (Table 2)

Table 2: Correspondence between terms in Heidelberg model of TCM and conventional medicine terms

\begin{tabular}{|l|l|}
\hline TCM (Heidelberg model) & Western terms \\
\hline Renal orb (paraorbis cerebri) & Higher nervous functions \\
\hline Cardial orb & Fluent fine regulation \\
\hline
\end{tabular}

If the Renal orb is not counterbalanced by the Cardial orb, then signs of phase Wood can appear (muscular spasticity, for instance). In general, these neurological symptoms are, according to TCM, ventus internus. At the same time Yang deficiency appears and causes lack of upward movement. In the system of the phases, Hepatic and Lienal vectors are affected, resulting in symptoms like lack of muscular power, lack of Xue within the limbs with flaccid palsy. This lack of $X u e$ can also be related with the model of the six stages $(A L T)$, explained previously.

According to the Heidelberg model of TCM the attack of the agent algor leads to production of reactive calor that has as a consequence a Splendor Yang syndrome (Stage II of the ALT), with accumulation of pituita (humor+calor). If this feature chronifies, can results in a Stage VI (Yang minor) with the Cardial (weak cardial Yin) and Renal orbs (paraorbis cerebri) involved. The Renal orb may produce a tendency to ventus internus. Frequently, a chronic Splendor Yang proceeds into a Yin minor syndrome (Stage VI of ALT) with expression of Cardiac and Renal symptoms. The presence of labile Qi makes also to appears signs of Stage I of ALT (Yang major). 
In summary, according to Greten (2010), MS shows lack of fluids, Yin and Yang deficiency and labile Qi (Figure 9).

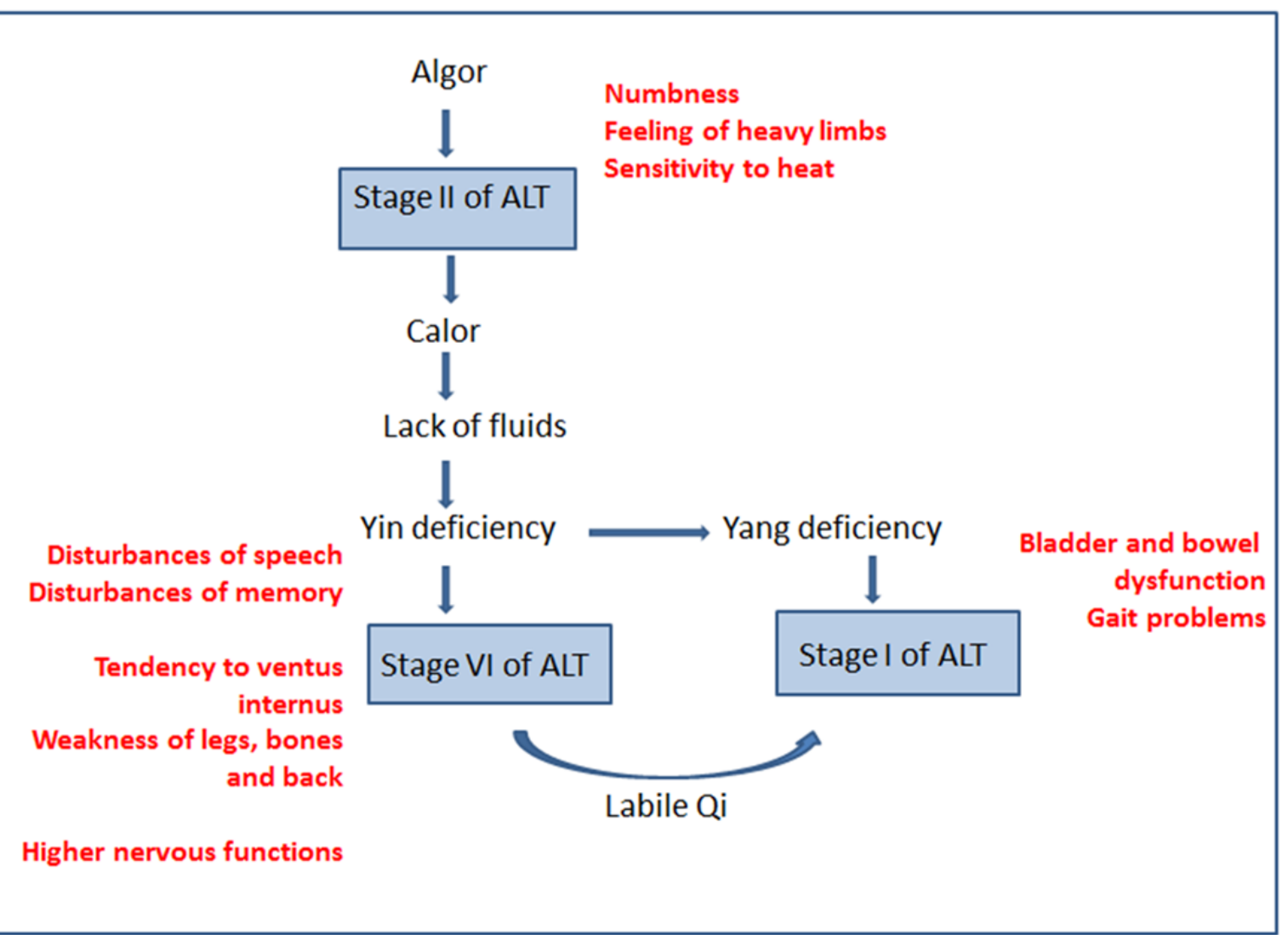

Figure 9: MS according to Heidelberg model of TCM. Adapted from Greten (2010). 
Effects of Acupuncture on Gait of Patients with Multiple Sclerosis 
2. CLINICAL RESEARCH PROTOCOL 
Effects of Acupuncture on Gait of Patients with Multiple Sclerosis 


\subsection{Aim of the study}

The main objective of the study is to evaluate the effect of a specific acupuncture protocol, according to Heidelberg model of TCM, in the gait impairment in patients with RelapseRemitting Multiple Sclerosis (RRMS).

\subsection{Sampling and Recruitment Procedures}

This study had the collaboration of the two associations of patients with MS with facilities in Oporto region: the "National Association for Multiple Sclerosis" (ANEM) and the "Portuguese Multiple Sclerosis Society" (SPEM). In both associations previous meetings were held to explain the objectives and the study design and the directors of both institutions showed their willingness to collaborate in the study (Annex 1). In addition, the study had the approval of the ethics commission of the Institute of Biomedical Sciences Abel Salazar (ICBAS) (Annex 2).

Prior to the development of the study, a free workshop was held in the SPEM (Annex 3 ) where aspects related to the objectives and design of the study, as well as the possible adverse effects of the treatment with acupuncture, was addressed. Doubts of patients regarding acupuncture treatment and, in general, to Traditional Chinese Medicine were also clarified. After this seminar, and before developing the study, patients who voluntarily showed their willingness to participate, signed the corresponding informed consent (Annex 4).

The criteria for inclusion/exclusion of the patients in the study are shown in Table 3

Table 3: Inclusion/exclusion criteria in the study

\begin{tabular}{|l|l|}
\hline \multicolumn{1}{|c|}{ Inclusion criteria } & \multicolumn{1}{c|}{ Exclusion criteria } \\
\hline $\begin{array}{l}\text { Patients with diagnosis of MS of } \\
\text { Relapse-Remitting type. }\end{array}$ & $\begin{array}{l}\text { Patients with diagnosis of other } \\
\text { pathologies. }\end{array}$ \\
\hline $18-70$ years of age. & Patients with psychiatric diseases. \\
\hline Stable symptoms in last two months. & $\begin{array}{l}\text { Patients with severe cognitive } \\
\text { deficiencies. }\end{array}$ \\
\hline $\begin{array}{l}\text { EDSS (Expanded Disability Status } \\
\text { Scale) between 3 and 7. }\end{array}$ & $\begin{array}{l}\text { EDSS (Expanded Disability Status } \\
\text { Scale) higher than 7. }\end{array}$ \\
\hline
\end{tabular}

After applying the inclusion/exclusion criteria, 20 patients were selected (Figure 10). 


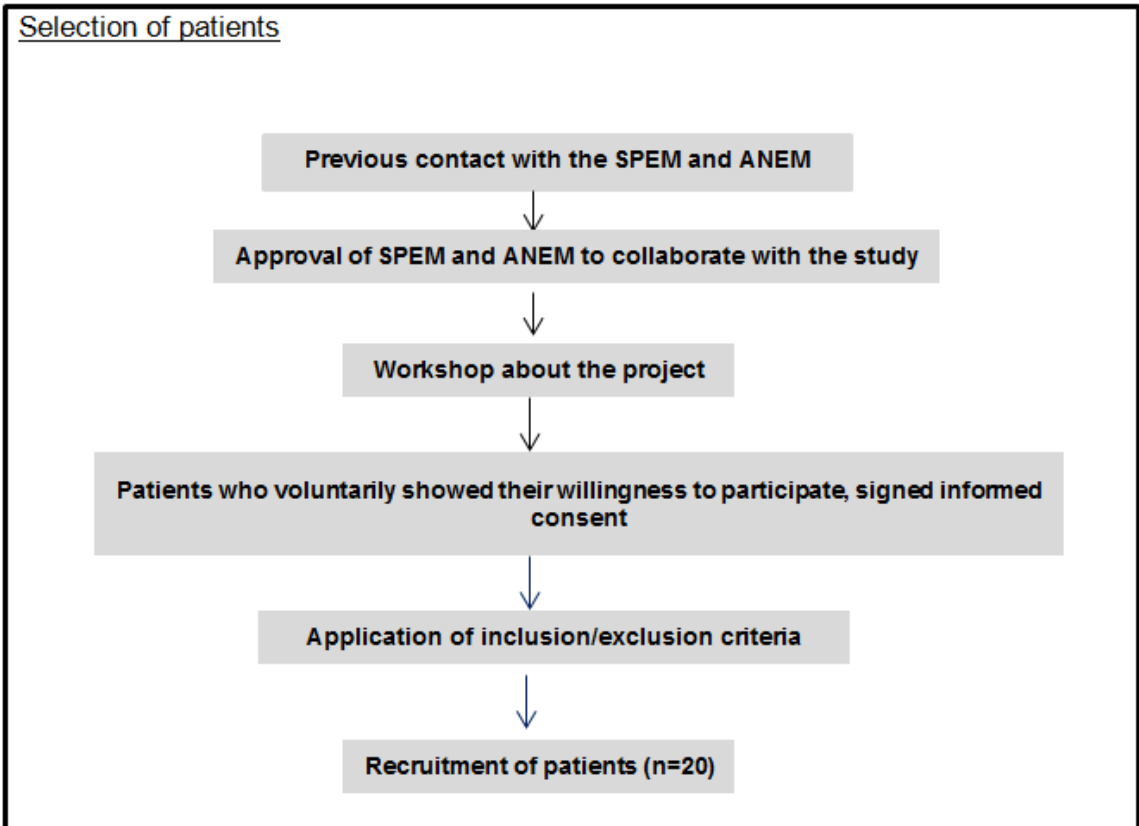

Figure 10: Schematic representation of the selection process

\subsection{Prospective randomized clinical study}

Initially, clinical and personal data of each patient were collected. Then, gait was evaluated in all patients. This evaluation was performed by the 25 -foot walk test (T25FW), a timed walking over a fixed distance measure, which has been extensively used to evaluate gait problems in neurological conditions and MS. The following instructions were given to patients for the completion of the test: "walk, as fast and safety as you can, across a clear marked linear 25 feet course. There are no turns, start is static and assistive device can be used" (Figure 11). After that, the same test was done but in a tandem walking way. Tandem gait is a method of walking (or running) where the toes of the back foot touch the heel of the front foot at each step (Figure 11). Neurologists sometimes ask patients to walk in a straight line using tandem gait as a test for unsteady gait to bring out abnormalities in gait and balance. Some disorders can cause unsteady gait, such as vision difficulties and problems with the motor neurons or associative cortex.
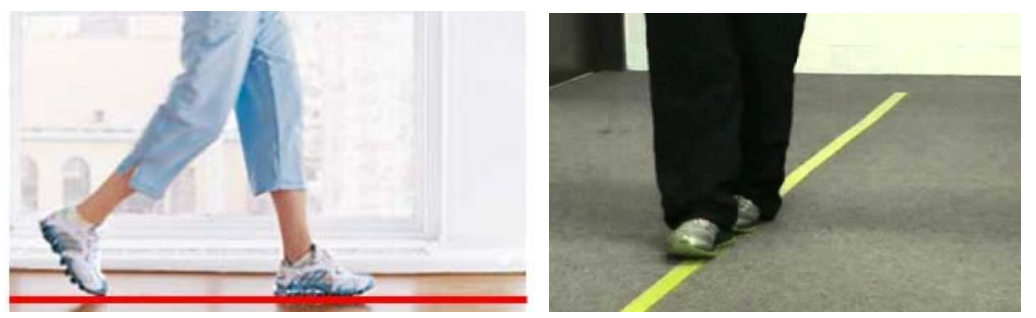

Figure 11: 25-Foot Walk Test (left); Tandem walking test (right) 
In addition to these tests, it was asked to all patients to complete the survey Multiple Sclerosis Walking Scale 12 (MSWS12). This survey consists of 12 questions that assess gait impairment in terms of the speed, distance and daily activities impact perceived by the patient. The MSWS-12 has been validated as a measure of walking function and as responsive to gait changes. The survey used in this study had been validated for Portuguese language (Nogueira et al, 2012) (Annex 5).

Patients were then randomized into one of two groups ( $A$ and $B$ ). The intervention was divided into two moments. In a first moment, A group patients received a "true acupuncture treatment", according to Heidelberg model, and patients of group B received "sham acupuncture treatment" (treatment using points not considered as the best according to Heidelberg model). All patients of the study were blinded to randomization assignments. Before and after each treatment, gait impairment evaluation was performed.

The second moment of intervention happened at least two weeks later. This time, group A of patients received "sham acupuncture" and group B "true acupuncture". Before and after each treatment, gait impairment evaluation was performed (Figure 12).

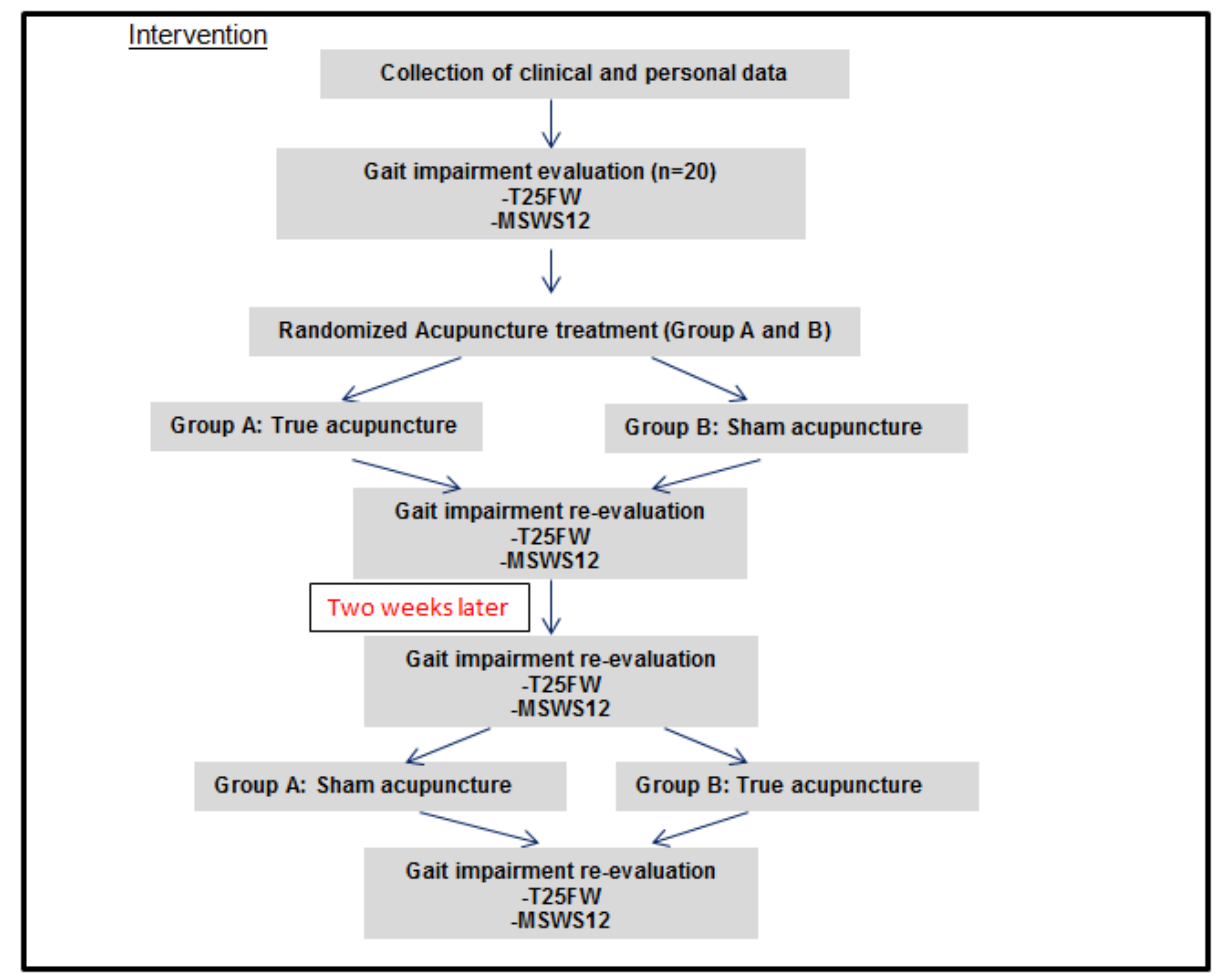

Figure 12: Schematic representation of the intervention process 


\section{Acupuncture protocol}

Acupuncture treatments were administered only by one acupuncturist (the researcher). For the study, a standardized acupuncture protocol was developed, based on Heidelberg Model of TCM. True acupuncture was done using acupuncture points, anatomically located in the lower extremities: S34 (ST34), V40 (BL40), V57 (BL57) (Figure 13) (Greten, 2012)

- V40 (B|40): Point activating the whole vesical conduit. It is useful in humor blockades leading to stiffness in the course of the vesical conduit. As a conjuntory, it is important for Yin deficiency. It also has an effect for ventus internus and spasm. It strengthens the loins and the knees.

- $\quad$ V57 (BI57): Important point if there is pain when walking. It enhances upward movement of the renal orb. It is also good for Reno-Lienal syndrome (a mild and chronic Yang deficiency). It has an effect in paralysis of lower extremities and tense muscles.

- $\quad$ S34 (ST34): Point that increase Qi flow. It dispels damp-cold (humor-algor). It is important in numbness and weakness and for pain in the knee and leg.

Sham acupuncture was done using points located 2 cun laterally to the ulnar border of the leg, out of any conduit.

Acupuncture technique called "Leopard spot technique" was used in the study. In this technique some drops of blood let out from peripheral points by quickly stabbing the skin (five or six times) with the needle (Chen et al, 2001; Saghaei and Razavi S, 2001). For this technique, sterile disposable needles with a size of $30 \mathrm{G}, 0,30 \times 8 \mathrm{~mm}$ were used (BD Micro-Fine $(\mathbb{R})$. This acupuncture technique is used to increase the flow of Qi and Xue and to disperse blood stasis.

Each session of acupuncture lasted approximately 20 minutes. 


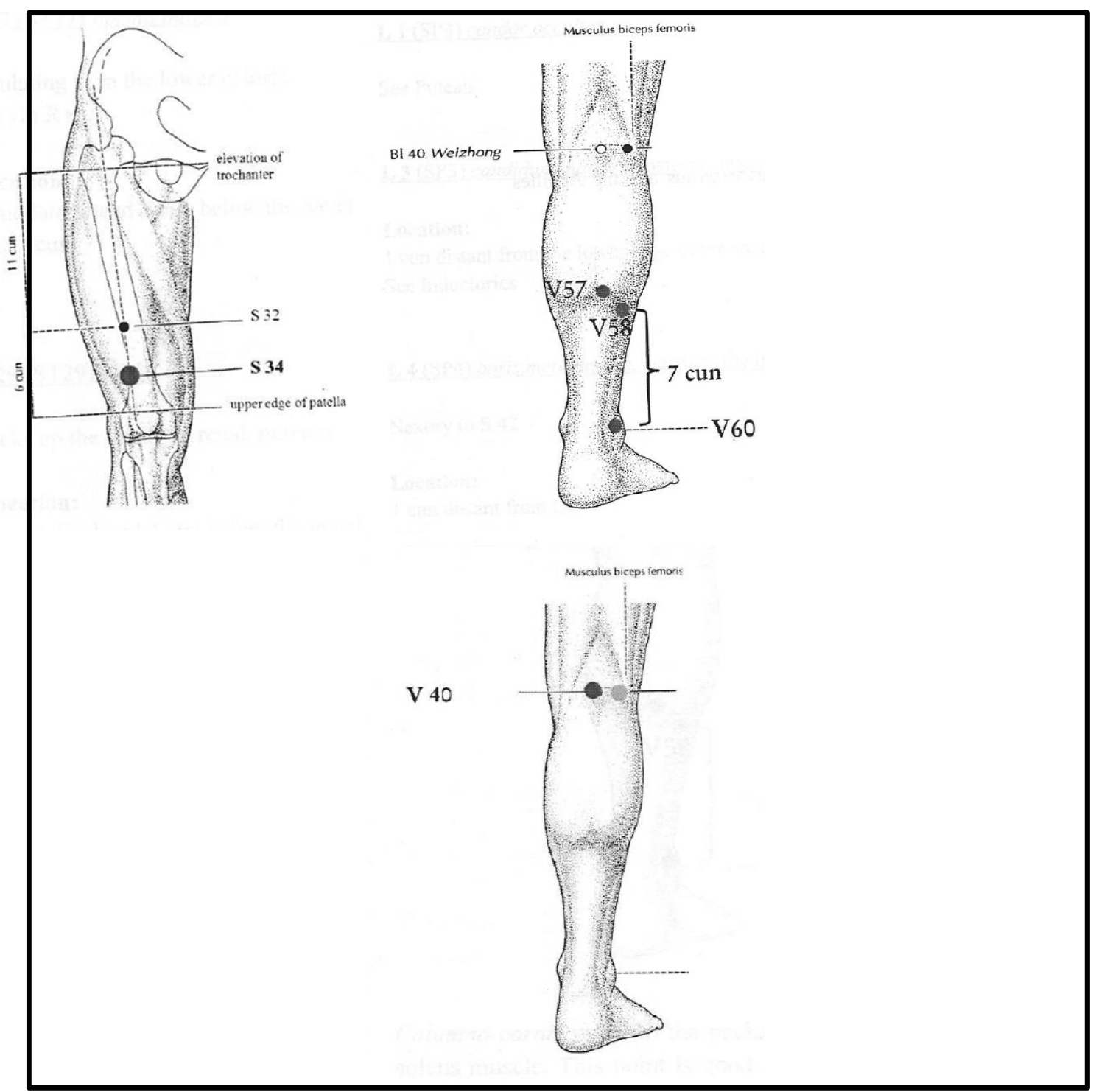

Figure 13: Anatomic localization of the acupuncture points used in the study according to Heidelberg model of TCM ("true acupuncture") Taken from Greten (2012)

\subsection{Statistical analysis}

For the execution of this work two softwares were used:

-Microsoft Excel $₫ 2010$. The use of this program gives advantages in the interpretation, organization and exploratory data analysis, particularly in relation to the descriptive statistics.

-SPSS (Statistical Package for Social Sciences)® Statistics 20 was used for comparisons. Nonparametric Wilcoxon for paired samples test was used to assess between-group comparisons as unadjusted analyses. Nonparametric tests had to be used because of the lack of normality distribution of data. All p-values below 0.05 were considered statistically significant. 
Effects of Acupuncture on Gait of Patients with Multiple Sclerosis 


\section{RESULTS}


Effects of Acupuncture on Gait of Patients with Multiple Sclerosis 


\subsection{Sample characterization}

The study sample consisted of 20 individuals. All of them were recruited from the two associations of patients with MS that are operating in Oporto region, ANEM and SPEM, as mentioned in the previous chapter. All the individuals had the diagnosis of multiple sclerosis of relapse-remitting type (RRMS), without any relapse in the previous two months. The collection of data was done during the months of June and July of 2014. Each patient was identified with a reference number. Socio-demographic and clinical characterizations of the 20 individuals of the sample are shown in Table 4.

Table 4: Socio-demographic and clinical characterization of the sample

\begin{tabular}{|c|c|c|c|c|c|c|c|c|}
\hline $\begin{array}{l}\text { Identification } \\
n^{\circ}\end{array}$ & $\begin{array}{c}\text { Sex } \\
*\end{array}$ & Age & $\begin{array}{c}\text { Time from } \\
\text { diagnosis } \\
\text { (years) }\end{array}$ & $\begin{array}{c}\text { Age at } \\
\text { diagnosis }\end{array}$ & $\begin{array}{l}\text { Date of last } \\
\text { relapse }\end{array}$ & $\begin{array}{c}\text { Main } \\
\text { complain }\end{array}$ & $\begin{array}{c}\text { Medication } \\
* *\end{array}$ & $\begin{array}{c}\text { Assistive } \\
\text { Devices } \\
* \star *\end{array}$ \\
\hline $01 /$ & $F$ & 45 & 1 & 44 & 2013 & Tiredness & Copaxone & $N$ \\
\hline $03 /$ & M & 50 & 8 & 42 & Before 2013 & Disbalance & Rebif & $N$ \\
\hline $04 /$ & $F$ & 49 & 15 & 34 & Before 2013 & Fatigue & $\begin{array}{l}\text { Without } \\
\text { medication }\end{array}$ & $\mathrm{N}$ \\
\hline $05 /$ & $M$ & 27 & 4 & 23 & 2013 & Fatigue & Natalizumab & $\mathrm{N}$ \\
\hline $06 /$ & $M$ & 54 & 24 & 30 & 1990 & loss memory & Copaxone & $\mathrm{N}$ \\
\hline $07 /$ & $F$ & 58 & 14 & 44 & 2000 & Disbalance & $?$ & $Y$ \\
\hline $08 /$ & $\mathrm{M}$ & 28 & 6 & 22 & 2011 & Tiredness & Lepicortinolo & $N$ \\
\hline $09 /$ & $\mathrm{M}$ & 25 & 6 & 21 & 2010 & Fatigue & Rebif & $\mathrm{N}$ \\
\hline $10 /$ & $F$ & 50 & 6 & 44 & 2008 & Disbalance & Rebif & $\mathrm{N}$ \\
\hline $11 /$ & $\mathrm{F}$ & 46 & 28 & 18 & $01 / 2014$ & Disbalance & Copaxone & $\mathrm{N}$ \\
\hline $13 /$ & $\mathrm{F}$ & 50 & 25 & 25 & Before 2013 & Disbalance & $?$ & $Y$ \\
\hline $14 /$ & $\mathrm{F}$ & 49 & 3 & 46 & 2011 & Tiredness & Rebif & $\mathrm{N}$ \\
\hline $15 /$ & $F$ & 61 & 2 & 59 & 2012 & Tiredness & Rebif & $Y$ \\
\hline $16 /$ & $F$ & 48 & 6 & 42 & $02 / 2014$ & Tyreness & Interferon B & Y \\
\hline $17 /$ & $F$ & 37 & 14 & 23 & 2013 & Tiredness & Fingolimod & $Y$ \\
\hline $18 /$ & $F$ & 52 & 7 & 45 & 2013 & Tiredness & Natalizumab & $\mathrm{N}$ \\
\hline $20 /$ & $M$ & 33 & 10 & 23 & 2004 & Spasm & $\begin{array}{l}\text { Without } \\
\text { medication }\end{array}$ & $\mathrm{N}$ \\
\hline $21 /$ & $F$ & 66 & 9 & 57 & 2005 & Disbalance & Interferon B & $N$ \\
\hline $22 /$ & M & 49 & 24 & 25 & 2010 & Disbalance & Copaxone & $N$ \\
\hline $23 /$ & $\mathrm{M}$ & 48 & 15 & 33 & $02 / 2014$ & Tiredness & Rebif & $\mathrm{N}$ \\
\hline
\end{tabular}

${ }^{\star} \mathrm{F}$ : Female; M: Male; ${ }^{* *}$ ?: the patient doesn't know the medication; ${ }^{* * *} \mathrm{~N}$ : No; Y: Yes

As we can see in Table 4, from the 20 patients, 12 were females $(60 \%)$ and 8 males $(40 \%)$ (see also Figure14). These results correspond to a female-male ratio of 1.5. 


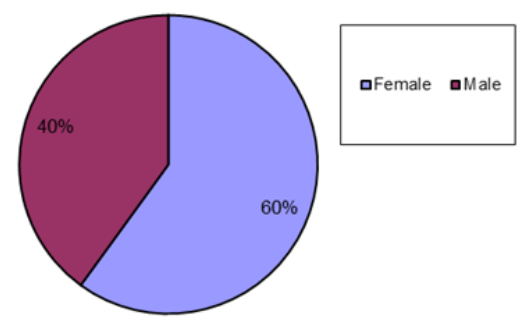

Figure 14: Distribution of the sample according to gender

With respect to quantitative variables, namely, age, time from diagnosis and age at diagnosis, Tables 5, 6 and 7 summarize the descriptive analysis, when considering the whole sample $(n=20)$ (Table 5$)$ and considering females $(n=12)$ (Table 6) and males $(n=8)$ (Table 7) separately.

Table 5: Descriptive analysis of age, time from diagnosis and the age at diagnosis when considered all individuals of the sample $(n=20)$

\begin{tabular}{|c|c|c|c|}
\hline $\mathrm{N}=20$ & Age & $\begin{array}{c}\text { Time from } \\
\text { diagnosis }\end{array}$ & Age at diagnosis \\
\hline Mean & 46,3 & 11,4 & 35 \\
\hline Median & 49,0 & 8,5 & 33.5 \\
\hline Maximum & 66,0 & 28,0 & 59 \\
\hline Minimum & 25,0 & 1,0 & 18 \\
\hline Standard deviation & 11,07 & 8,25 & 12,44 \\
\hline
\end{tabular}

Table 6: Descriptive analysis of age, the time from diagnosis and the age at diagnosis for females in the sample $(n=12)$

\begin{tabular}{|c|c|c|c|}
\hline $\mathrm{N}=12$ & Age & $\begin{array}{c}\text { Time from } \\
\text { diagnosis }\end{array}$ & Age at diagnosis \\
\hline Mean & 50,9 & 10,8 & 40.1 \\
\hline Median & 49,5 & 8,0 & 44 \\
\hline Maximum & 66,0 & 28,0 & 59 \\
\hline Minimum & 37,0 & 1,0 & 18 \\
\hline Standard deviation & 7,69 & 8,71 & \\
\hline
\end{tabular}


Table 7: Descriptive analysis of age, the time from diagnosis and the age at diagnosis for males in the sample $(n=8)$

\begin{tabular}{|c|c|c|c|}
\hline $\mathrm{N}=8$ & Age & $\begin{array}{c}\text { Time from } \\
\text { diagnosis }\end{array}$ & Age at diagnosis \\
\hline Mean & 39,3 & 12,1 & 27.4 \\
\hline Median & 40,5 & 9,0 & 24 \\
\hline Maximum & 54,0 & 24,0 & 42 \\
\hline Minimum & 25,0 & 4,0 & 21 \\
\hline Standard deviation & 12,09 & 8,04 & \\
\hline
\end{tabular}

According to our data, both, the mean age and the mean age at diagnostic were lower in males than in females.

Figure 15, Figure 16 and Figure 17 present the frequency distribution of the qualitative variables described in Table 4, namely, main complain, medication and the use of assistive devices, considering female and male patients separately.

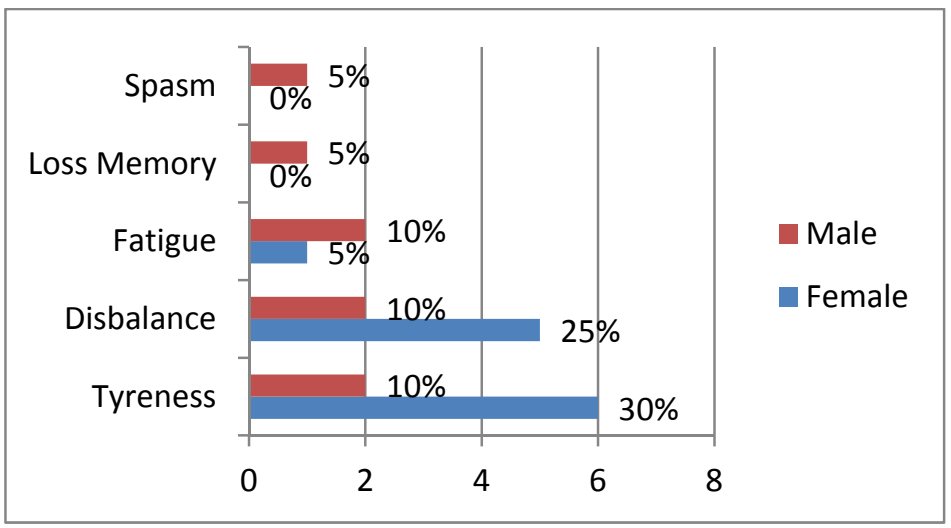

Figure 15: Frequency distribution (\%) of the main complain of the patients

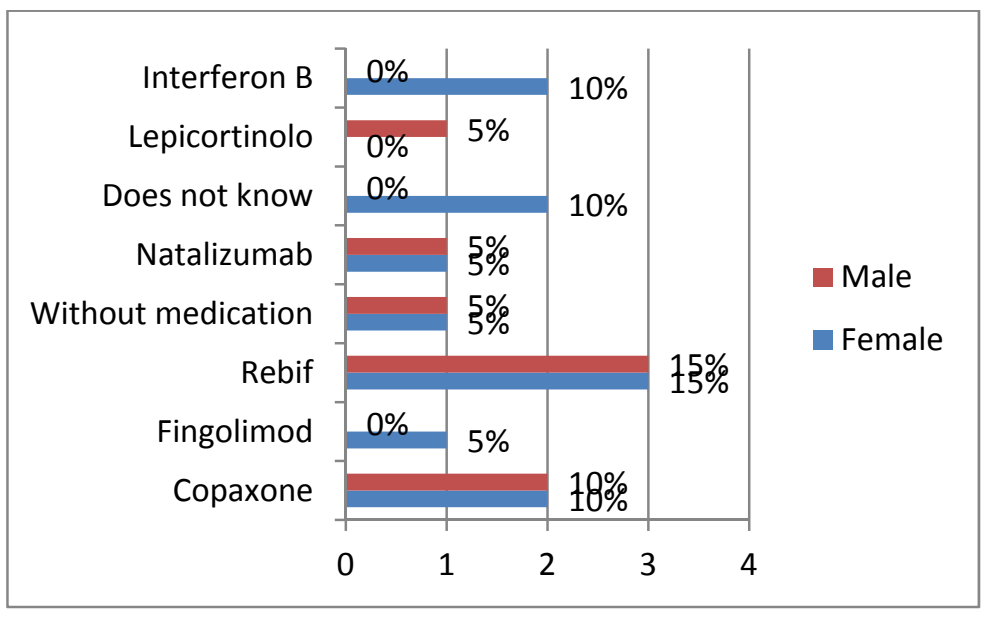

Figure 16: Frequency distribution (\%) of the medication used 


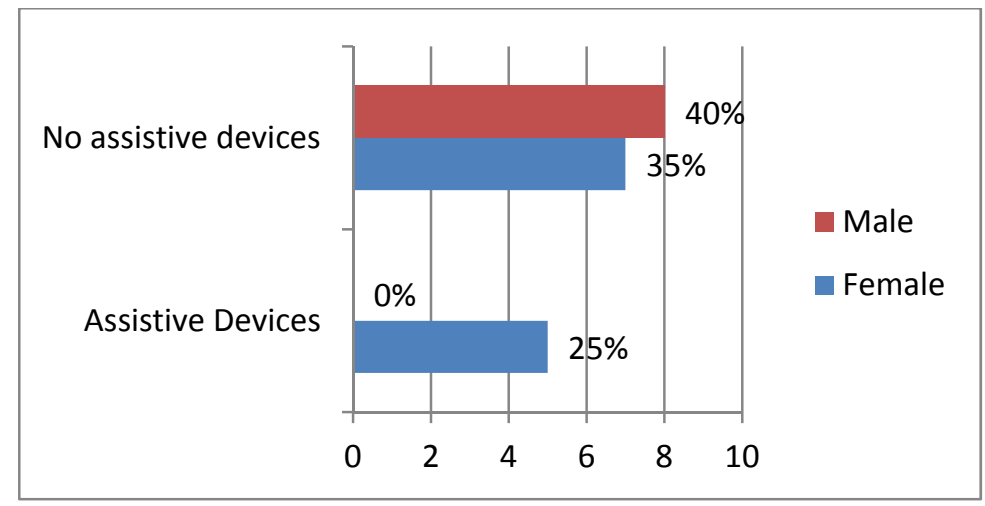

Figure 17: Frequency distribution (\%) of the use of assistive devices

\subsection{Gait assessment before and after acupuncture treatment (25-Foot Walk test)}

Results of the 25-Foot Walk test (T25FW) were measured in seconds. Table 8 shows the results obtained before and after each true acupuncture and sham acupuncture treatment. The corresponding percentage of improvement experienced by each patient is also shown for each treatment.

Table 8: Results of the 25-Foot Walk test before and after true and sham acupuncture

\begin{tabular}{|c|c|c|c|c|c|c|}
\hline \multirow[b]{2}{*}{$\begin{array}{l}\text { Identification } \\
\mathrm{n}^{\circ}\end{array}$} & \multicolumn{3}{|c|}{ True acupuncture } & \multicolumn{3}{|c|}{ Sham acupuncture } \\
\hline & $\begin{array}{l}\text { T25FW- } \\
\text { before } \\
\text { (seconds) }\end{array}$ & $\begin{array}{l}\text { T25FW-after } \\
\text { (seconds) }\end{array}$ & $\begin{array}{c}\% \\
\text { improvement }\end{array}$ & $\begin{array}{l}\text { T25FW- } \\
\text { before } \\
\text { (seconds) }\end{array}$ & $\begin{array}{c}\text { T25FW-after } \\
\text { (seconds) }\end{array}$ & $\begin{array}{c}\% \\
\text { improvement }\end{array}$ \\
\hline $01 /$ & 10,3 & 8,8 & $14,60 \%$ & 8,7 & 9,2 & $6,20 \%$ \\
\hline $03 /$ & 12,7 & 12 & $5,40 \%$ & 12,7 & 15,3 & $-21,00 \%$ \\
\hline $04 /$ & 8,2 & 7,3 & $11,30 \%$ & 6,8 & 6,9 & $-1,30 \%$ \\
\hline 05/ & 8,4 & 6,7 & $20,30 \%$ & 6 & 5,9 & $1,20 \%$ \\
\hline $06 /$ & 7,0 & 6,7 & $4,40 \%$ & 7 & 6,3 & $9,90 \%$ \\
\hline $07 /$ & 40,4 & 31 & $23,40 \%$ & 40,6 & 23,7 & $41,50 \%$ \\
\hline $08 /$ & 12,9 & 10,2 & $20,70 \%$ & 15 & 17,7 & $-17,40 \%$ \\
\hline $09 /$ & 5,3 & 4,4 & $16,60 \%$ & 5,4 & 5,6 & $-2,20 \%$ \\
\hline $10 /$ & 6,8 & 5,9 & $13,20 \%$ & 7,3 & 5,8 & $20,20 \%$ \\
\hline $11 /$ & 22,1 & 14,8 & $33,00 \%$ & 17,9 & 19,8 & $-9,90 \%$ \\
\hline $13 /$ & 26,9 & 25,1 & $6,60 \%$ & 18,5 & 17,6 & $4,90 \%$ \\
\hline $14 /$ & 12,7 & 9,8 & $23,10 \%$ & 11,2 & 13,4 & $-19,50 \%$ \\
\hline $15 /$ & 16,9 & 15,6 & $7,80 \%$ & 16,6 & 14,2 & $14,80 \%$ \\
\hline $16 /$ & 16,2 & 10,7 & $33,50 \%$ & 9,7 & 12,4 & $-27,90 \%$ \\
\hline $17 /$ & 15,2 & 9,4 & $38,40 \%$ & 14,6 & 15,3 & $-4,70 \%$ \\
\hline $18 /$ & 9,7 & 10,1 & $-3,60 \%$ & 9,7 & 10,2 & $-5,40 \%$ \\
\hline $20 /$ & 7,7 & 7,7 & 0 & 8,6 & 8,4 & $1,90 \%$ \\
\hline $21 /$ & 9,1 & 8,7 & $4,60 \%$ & 9 & 8,7 & $3,90 \%$ \\
\hline $22 /$ & 7,6 & 7,5 & $1,20 \%$ & 6,2 & 6,4 & $-2,40 \%$ \\
\hline $23 /$ & 6,2 & 6,2 & 0 & 6,7 & 7,8 & $-15,70 \%$ \\
\hline
\end{tabular}


Descriptive statistics of the results for the 25-Foot Walk test before and after each treatment of acupuncture are shown in Table 9 and Figure $18(n=20)$, Table 10 and Figure 19 (males sample), and Table 11 and Figure 20 (females sample).

Table 9: Descriptive analysis of T25FW results before and after each acupuncture treatment for the whole sample

\begin{tabular}{|c|c|c|c|c|}
\hline & \multicolumn{2}{|c|}{ True acupuncture } & \multicolumn{2}{c|}{ Sham acupuncture } \\
\hline $\mathrm{N}=20$ & $\begin{array}{c}\text { Before } \\
\text { Treatment } \\
\text { (seconds) }\end{array}$ & $\begin{array}{c}\text { After } \\
\text { treatment }\end{array}$ & $\begin{array}{c}\text { Before } \\
\text { treatment }\end{array}$ & $\begin{array}{c}\text { After } \\
\text { treatment }\end{array}$ \\
\hline Mean & 13,1 & 10,9 & 11,9 & 11,5 \\
\hline Median & 10,0 & 9,1 & 9,4 & 9,7 \\
\hline Maximum & 40,4 & 31,0 & 40,6 & 23,7 \\
\hline Minimum & 5,3 & 4,4 & 5,4 & 5,6 \\
\hline Standard deviation & 8,50 & 6,56 & 7,92 & 5,36 \\
\hline
\end{tabular}

Table 10: Descriptive analysis of T25FW results before and after each acupuncture treatment for males sample

\begin{tabular}{|c|c|c|c|c|}
\hline & \multicolumn{2}{|c|}{ True acupuncture } & \multicolumn{2}{c|}{ Sham acupuncture } \\
\hline $\mathrm{N}=8$ & $\begin{array}{c}\text { Before } \\
\text { treatment }\end{array}$ & $\begin{array}{c}\text { After } \\
\text { treatment }\end{array}$ & $\begin{array}{c}\text { Before } \\
\text { treatment }\end{array}$ & $\begin{array}{c}\text { After } \\
\text { treatment }\end{array}$ \\
\hline Mean & 8,5 & 7,7 & 8,5 & 9,2 \\
\hline Median & 7,7 & 7,1 & 6,9 & 7,1 \\
\hline Maximum & 12,9 & 12,0 & 15,0 & 17,7 \\
\hline Minimum & 5,3 & 4,4 & 5,4 & 5,6 \\
\hline Standard deviation & 2,83 & 2,39 & 3,52 & 4,66 \\
\hline
\end{tabular}

Table 11: Descriptive analysis of T25FW results before and after each acupuncture treatment for females sample

\begin{tabular}{|c|c|c|c|c|}
\hline & \multicolumn{2}{|c|}{ True acupuncture } & \multicolumn{2}{c|}{ Sham acupuncture } \\
\hline $\mathrm{N}=12$ & $\begin{array}{c}\text { Before } \\
\text { treatment }\end{array}$ & $\begin{array}{c}\text { After } \\
\text { treatment }\end{array}$ & $\begin{array}{c}\text { Before } \\
\text { treatment }\end{array}$ & $\begin{array}{c}\text { After } \\
\text { treatment }\end{array}$ \\
\hline Mean & 16,2 & 13,1 & 14,2 & 13,1 \\
\hline Median & 14,0 & 10,0 & 10,5 & 12,9 \\
\hline Maximum & 40,4 & 31,0 & 40,6 & 23,7 \\
\hline Minimum & 6,8 & 5,9 & 6,8 & 5,8 \\
\hline Standard deviation & 9,67 & 7,61 & 9,26 & 5,38 \\
\hline
\end{tabular}




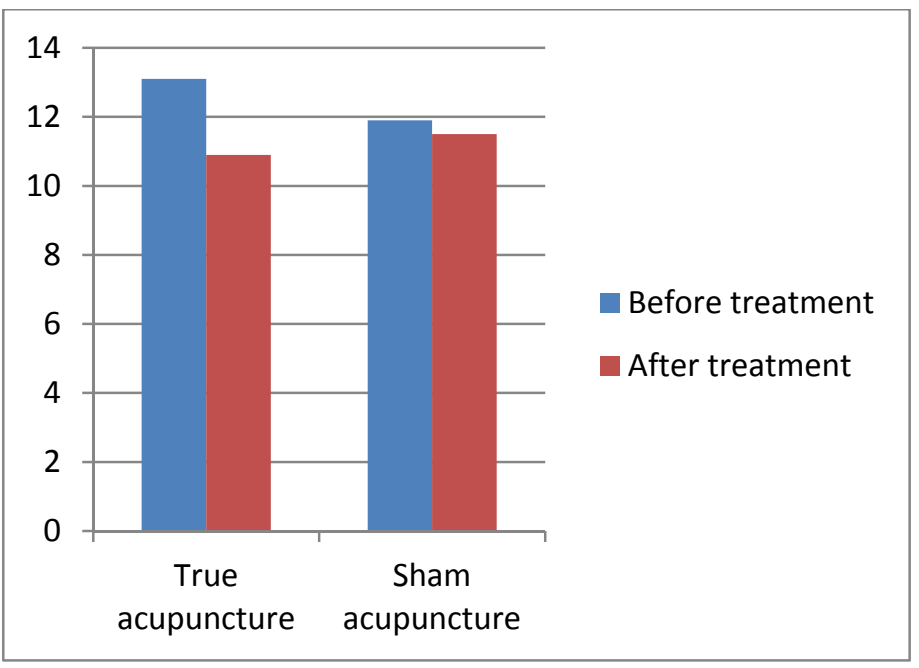

Figure 18: Mean of the T25FW results (seconds) before and after each acupuncture treatment for the whole sample

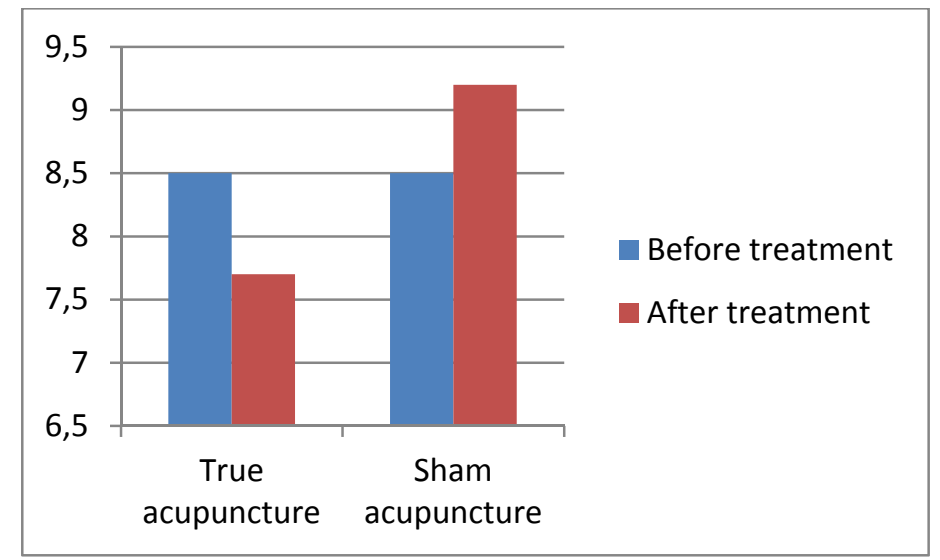

Figure 19: Mean of the T25FW results (seconds) before and after each acupuncture treatment for the male sample

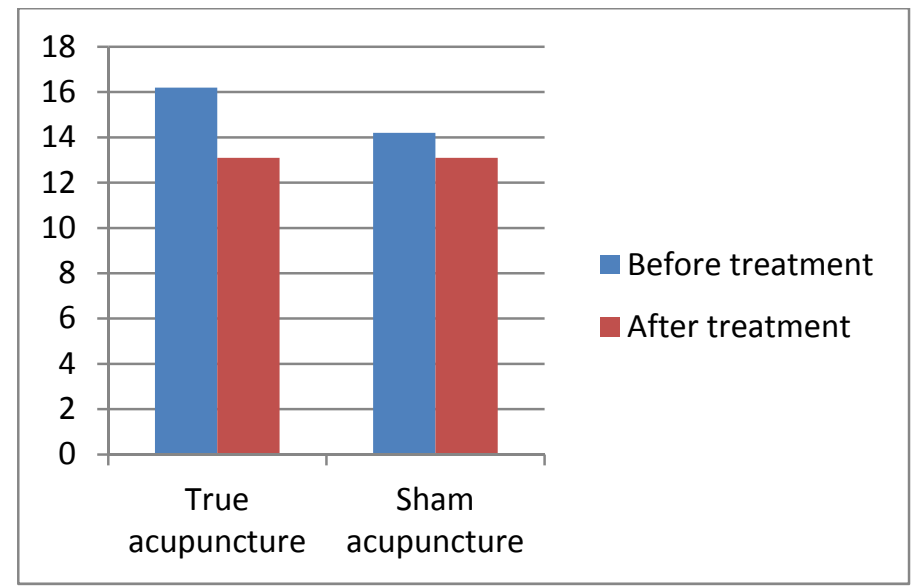

Figure 20: Mean of the T25FW results (seconds) before and after each acupuncture treatment for the female sample 
The percentage of improvement for each individual with respect to the T25FW when true acupuncture was done is shown in Figure 21 and in Figure 22 when sham acupuncture was done.

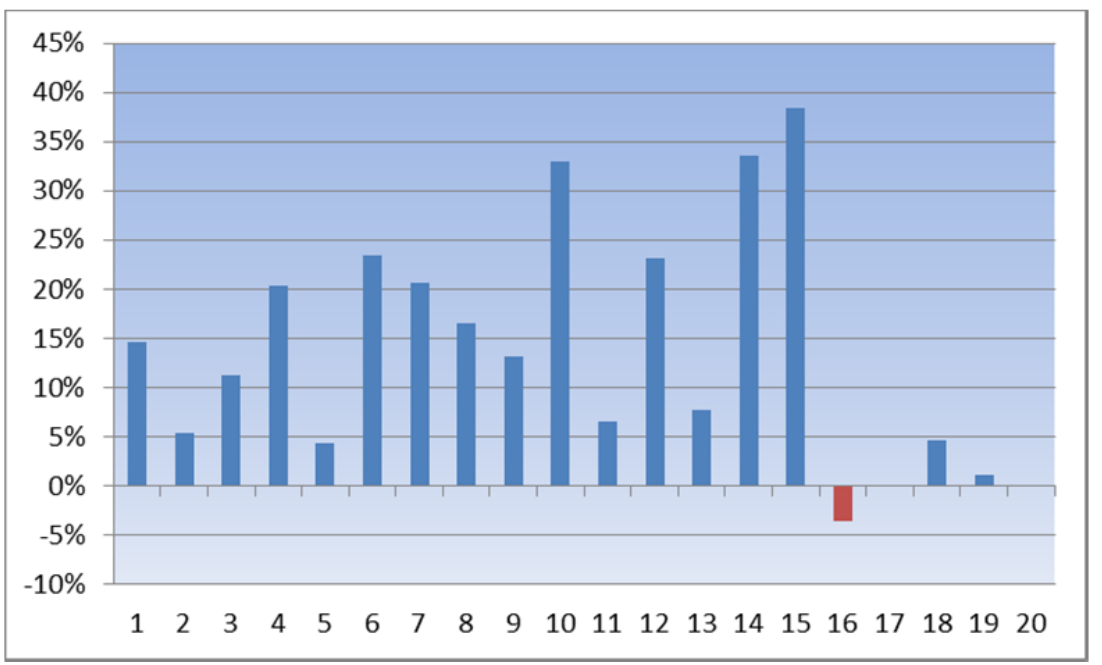

Figure 21: Percentage of improvement in the T25FW for true acupuncture

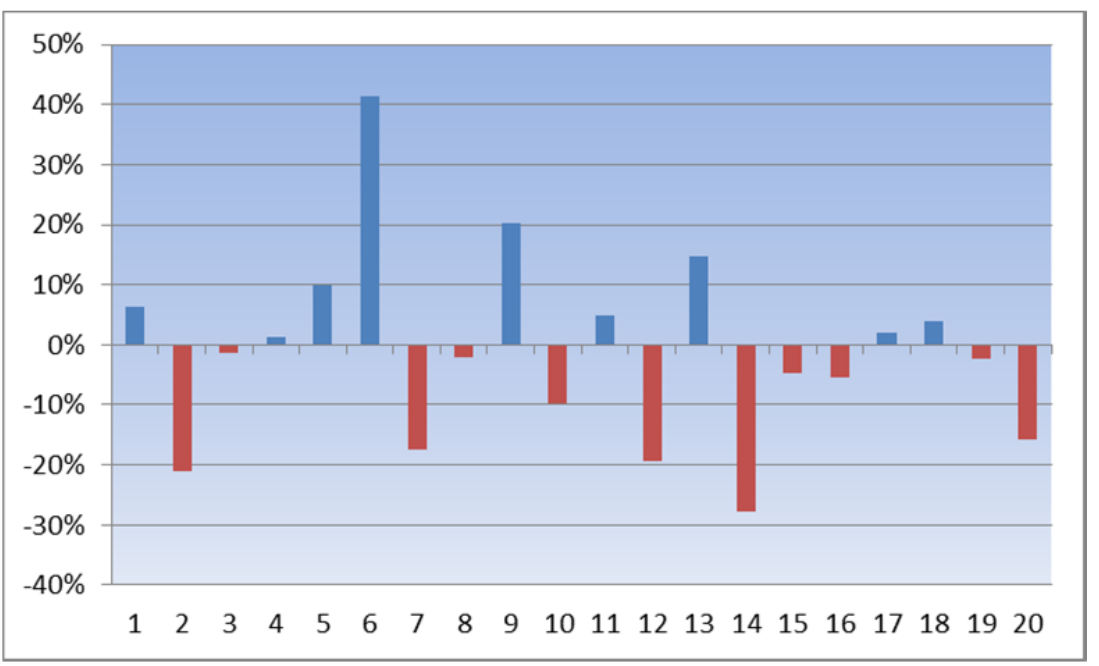

Figure 22: Percentage of improvement in T25FW for sham acupuncture

All except three patients improved the performance of the T25FW when true acupuncture was done (Figure 21). Also, we found a mean percentage of improvement of $13.9 \%$ when considering the sample as a whole. Analysing males and females separately we found that for females the mean percentage of improvement was $17.5 \%$ and for males it was $8.6 \%$.

When sham acupuncture was done, although some patients improved the performance of the test, we cannot see a positive mean percentage of improvement (Figure 22). 
To study the differences between the results of the 25-Foot Walk test we applied the Wilcoxon test for paired samples (Table 12). As can be seen in Table 12, when true acupuncture was done the results before and after treatment were statistically significant $(p<0.05)$ for the whole sample, and when we considered males and females separately. In none of the cases the results before and after treatment with sham acupuncture were statistically significant.

Table 12: Results of the Wilcoxon test applied to the analysis of T25FW results

\begin{tabular}{|c|c|c|}
\hline & True acupuncture & Sham acupuncture \\
\hline $\mathrm{N}=20$ & Before vs After & Before vs After \\
\hline Significance & $0.000^{*}$ & 0.370 \\
\hline $\begin{array}{c}\text { Male sample } \\
\mathrm{N}=8\end{array}$ & Before vs After & Before vs After \\
\hline $\begin{array}{c}\text { Significance } \\
\text { Female sample } \\
\mathrm{N}=12\end{array}$ & $0.028^{*}$ & 0.205 \\
\hline Significance & $0.003^{*}$ & Before vs After \\
\hline
\end{tabular}

*: Statistically significant $(p<0.05)$ 


\subsection{Gait assessment before and after acupuncture treatment (Tandem walking test)}

Results of the Tandem walking test (TWT) were measured in seconds. Table 13 shows the results obtained before and after true acupuncture and sham acupuncture treatments. The corresponding percentage of improvement experienced by each patient is also shown. From the 20 patients, 15 could perform the test, while for the other 5 patients it was not possible.

Table 13: Results of the Tandem walking test before and after true and sham acupuncture treatment

\begin{tabular}{|c|c|c|c|c|c|c|}
\hline \multirow[b]{2}{*}{$\begin{array}{c}\text { Identification } \\
n^{\circ}\end{array}$} & \multicolumn{3}{|c|}{ True acupuncture } & \multicolumn{3}{|c|}{ Sham acupuncture } \\
\hline & $\begin{array}{l}\text { TWT-Before } \\
\text { (Secons) }\end{array}$ & $\begin{array}{l}\text { TWT-After } \\
\text { (Seconds) }\end{array}$ & $\begin{array}{c}\% \\
\text { improvement }\end{array}$ & $\begin{array}{l}\text { TWT-Before } \\
\text { (Seconds) }\end{array}$ & $\begin{array}{l}\text { TWT-After } \\
\text { (Seconds) }\end{array}$ & $\begin{array}{c}\% \\
\text { improvement }\end{array}$ \\
\hline $01 /$ & 32,38 & 16,78 & $48,20 \%$ & 23,2 & 19,34 & $16,60 \%$ \\
\hline $03 /$ & 58,5 & 47,12 & $19,50 \%$ & 58,5 & 55,5 & $5,10 \%$ \\
\hline $04 /$ & 17,18 & 13,68 & $20,40 \%$ & 10,37 & 12,22 & $-17,80 \%$ \\
\hline 05/ & 31,02 & 21,52 & $30,60 \%$ & 22,15 & 19,65 & $11,30 \%$ \\
\hline $06 /$ & 22,19 & 18,42 & $17,00 \%$ & 25,56 & 15,82 & $38,10 \%$ \\
\hline $07 /$ & - & - & - & - & - & - \\
\hline $08 /$ & 23,96 & 18,7 & $21,90 \%$ & 24,66 & 18,07 & $26,70 \%$ \\
\hline $09 /$ & 19,87 & 19,23 & $3,20 \%$ & 21,27 & 20,22 & $4,90 \%$ \\
\hline $10 /$ & 27,7 & 23,91 & $13,70 \%$ & 32,53 & 25,05 & $22,90 \%$ \\
\hline $11 /$ & - & - & - & - & - & - \\
\hline $13 /$ & 40,81 & 28,48 & $30,20 \%$ & 19,8 & 17,4 & $12,40 \%$ \\
\hline $14 /$ & 33,24 & 24,85 & $25,20 \%$ & 26,41 & 28,09 & $-6,40 \%$ \\
\hline $15 /$ & - & - & - & - & - & - \\
\hline $16 /$ & - & - & - & - & - & - \\
\hline $17 /$ & 39,92 & 19,43 & $51,30 \%$ & 29,1 & 20,3 & $30 \%$ \\
\hline $18 /$ & 24,57 & 17,85 & $27,40 \%$ & 24,9 & 25,1 & $-0,80 \%$ \\
\hline $20 /$ & 34,4 & 28,8 & $16,20 \%$ & 28,4 & 29,4 & $-3,40 \%$ \\
\hline $21 /$ & - & - & - & - & - & - \\
\hline 221 & 107,11 & 40,18 & $62,50 \%$ & 40,61 & 23,45 & $42,20 \%$ \\
\hline $23 /$ & 23,12 & 20,77 & $10,20 \%$ & 26,3 & 21,2 & $19,10 \%$ \\
\hline
\end{tabular}

Descriptive statistics of the results for the Tandem walking test, before and after each treatment of acupuncture, are shown in Table 14 and Figure $23(n=20)$, Table 15 and Figure 24 (male sample), and Table 16 and Figure 25 (female sample). 
Table 14: Descriptive analysis of Tandem walking results before and after each acupuncture treatment for the whole sample

\begin{tabular}{|c|c|c|c|c|}
\hline & \multicolumn{2}{|c|}{ True acupuncture } & \multicolumn{2}{c|}{ Sham acupuncture } \\
\hline $\mathrm{N}=\mathbf{2 0}$ & $\begin{array}{c}\text { Before } \\
\text { treatment }\end{array}$ & $\begin{array}{c}\text { After } \\
\text { treatment }\end{array}$ & $\begin{array}{c}\text { Before } \\
\text { treatment }\end{array}$ & $\begin{array}{c}\text { After } \\
\text { treatment }\end{array}$ \\
\hline Mean & 35,7 & 24,0 & 27,6 & 23,4 \\
\hline Median & 31,0 & 20,8 & 25,6 & 20,3 \\
\hline Maximum & 107,1 & 47,1 & 58,5 & 55,5 \\
\hline Minimum & 17,2 & 13,7 & 10,4 & 12,2 \\
\hline Standard deviation & 22,30 & 9,09 & 10,76 & 9,99 \\
\hline
\end{tabular}

Table 15: Descriptive analysis of Tandem walking results before and after each acupuncture treatment for the male sample

\begin{tabular}{|c|c|c|c|c|}
\hline & \multicolumn{2}{|c|}{ True acupuncture } & \multicolumn{2}{c|}{ Sham acupuncture } \\
\hline $\mathrm{N}=8$ & $\begin{array}{c}\text { Before } \\
\text { treatment }\end{array}$ & $\begin{array}{c}\text { After } \\
\text { treatment }\end{array}$ & $\begin{array}{c}\text { Before } \\
\text { treatment }\end{array}$ & $\begin{array}{c}\text { After } \\
\text { treatment }\end{array}$ \\
\hline Mean & 40,0 & 26,8 & 30,9 & 25,4 \\
\hline Median & 27,5 & 21,1 & 25,9 & 20,7 \\
\hline Maximum & 107,1 & 47,1 & 58,5 & 55,5 \\
\hline Minimum & 19,9 & 18,4 & 21,3 & 15,8 \\
\hline Standard deviation & 29,82 & 11,04 & 12,65 & 12,81 \\
\hline
\end{tabular}

Table 16: Descriptive analysis of Tandem walking results before and after each acupuncture treatment for the female sample

\begin{tabular}{|c|c|c|c|c|}
\hline & \multicolumn{2}{|c|}{ True acupuncture } & \multicolumn{2}{c|}{ Sham acupuncture } \\
\hline $\mathrm{N}=12$ & $\begin{array}{c}\text { Before } \\
\text { treatment }\end{array}$ & $\begin{array}{c}\text { After } \\
\text { treatment }\end{array}$ & $\begin{array}{c}\text { Before } \\
\text { treatment }\end{array}$ & $\begin{array}{c}\text { After } \\
\text { treatment }\end{array}$ \\
\hline Mean & 30,8 & 20,7 & 23,8 & 21,1 \\
\hline Median & 32,4 & 19,4 & 24,9 & 20,3 \\
\hline Maximum & 40,8 & 28,5 & 32,5 & 28,1 \\
\hline Minimum & 17,2 & 13,7 & 10,4 & 12,2 \\
\hline Standard deviation & 8,42 & 5,20 & 7,18 & 5,43 \\
\hline
\end{tabular}




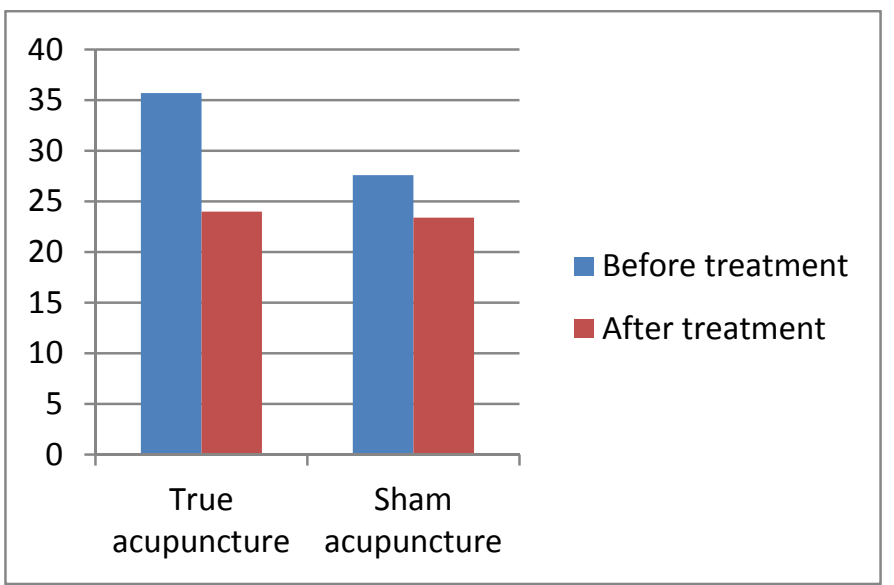

Figure 23: Mean of the Tandem walking test results (seconds) before and after each acupuncture treatment for the whole sample

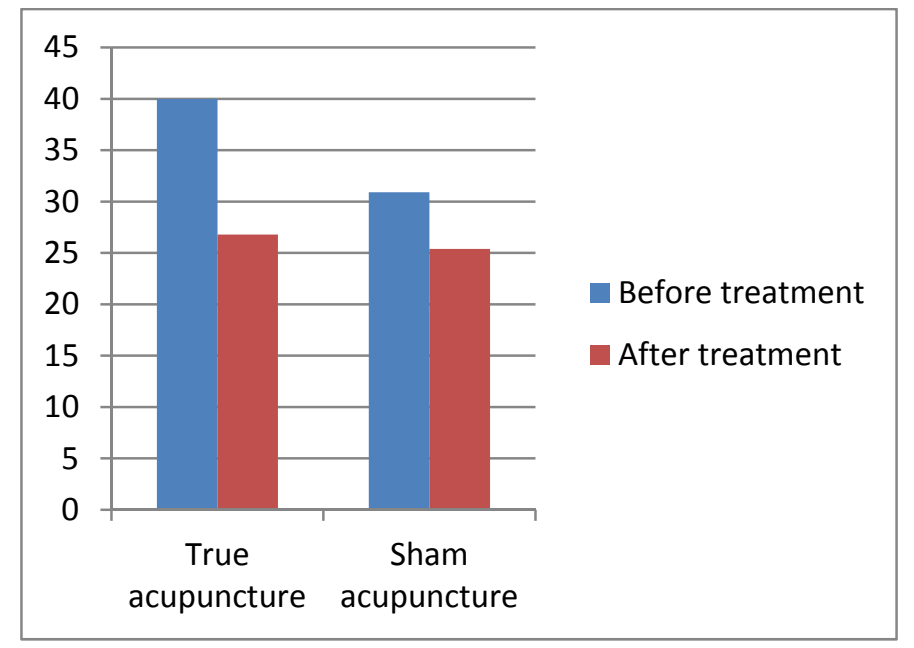

Figure 24: Mean of the Tandem walking test results (seconds) before and after each acupuncture treatment for the male sample

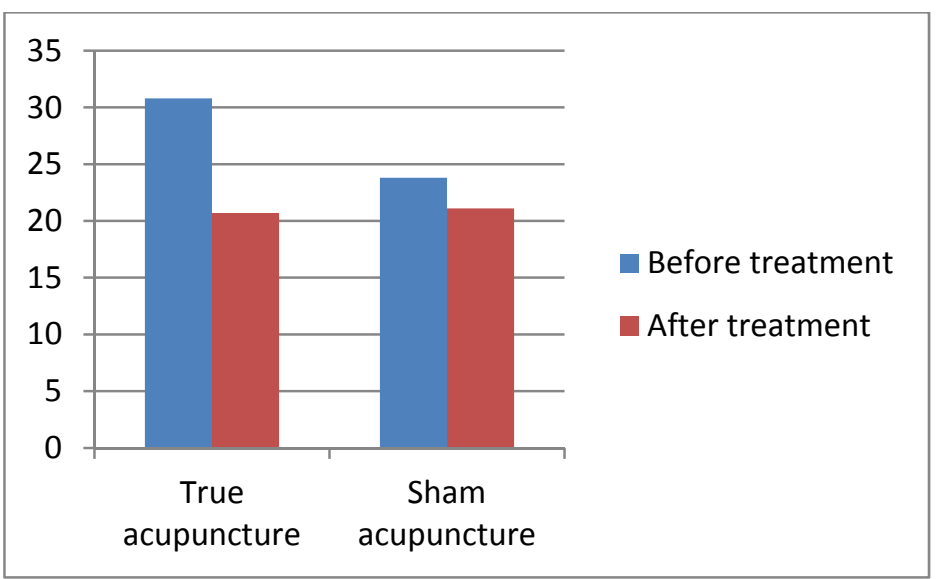

Figure 25: Mean of the Tandem walking test results (seconds) before and after each acupuncture treatment for the female sample 
When we analyse the mean values of the results of the Tandem walking test we can see that after true acupuncture treatment, there was an improvement in the performance of the test when we consider the whole sample, and also considering male and female samples separately. The same situation is observed after sham acupuncture, the mean value of the results was lower than before the treatment for the whole sample, and for male and female samples.

Figure 26 presents the percentages of improvement with respect to the Tandem walking test when true acupuncture was done and Figure 27 presents the results when sham acupuncture was done.

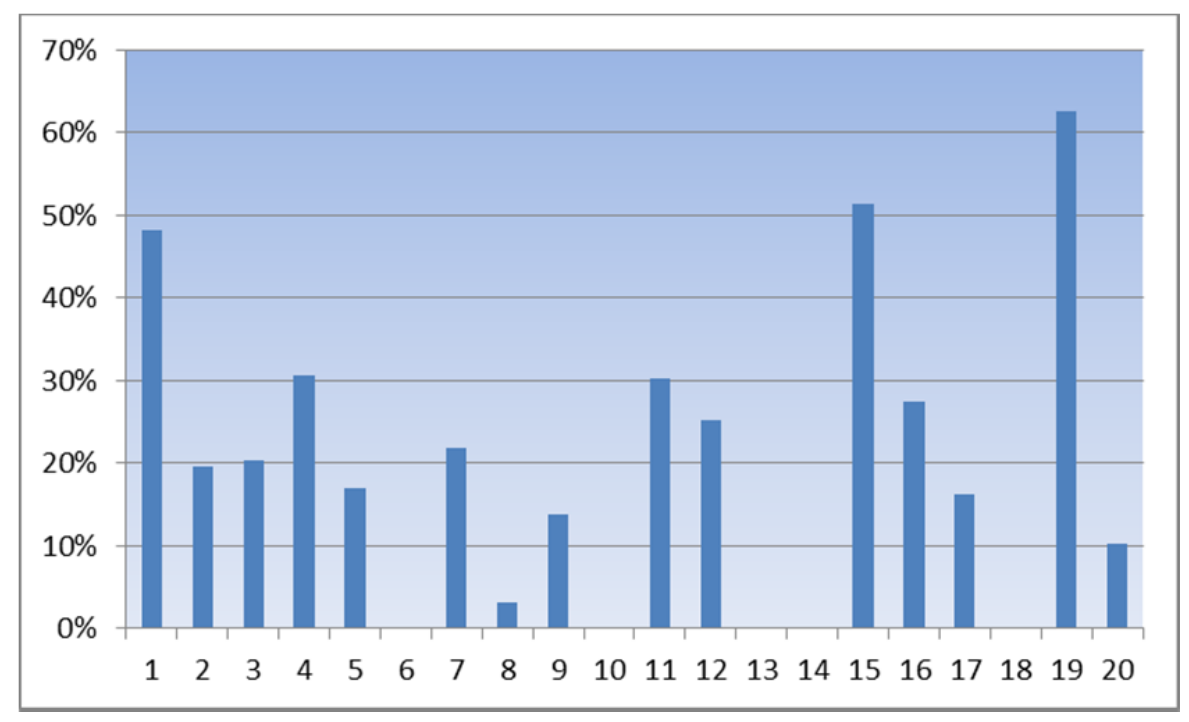

Figure 26: Percentage of improvement in Tandem walking test for true acupuncture

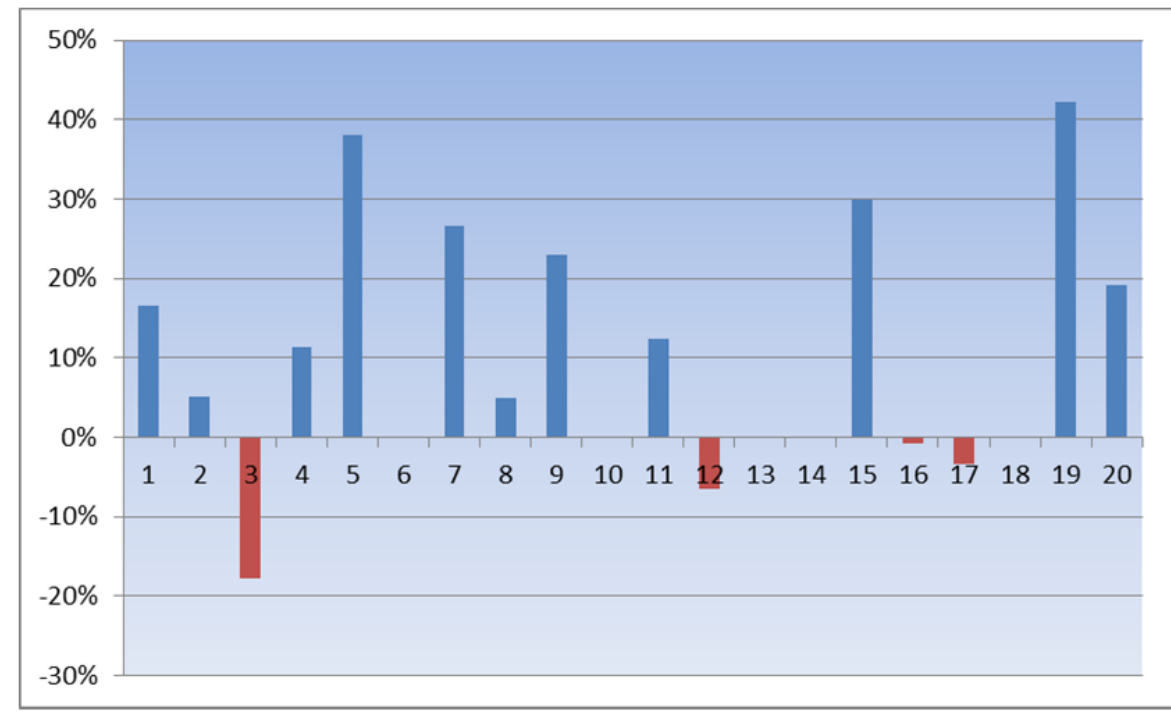

Figure 27: Percentage of improvement in Tandem walking test for sham acupuncture 
For the whole sample $(n=20)$ we found that when true acupuncture treatment was done, the mean of the percentage of improvement was $26,5 \%$. Analysing males and females separately we found that for the female sample the mean percentage of improvement was $30,9 \%$ and for the male sample it was $22.6 \%$. When sham acupuncture was done, the mean of percentage of improvement was $13.4 \%$ when we analysed the whole sample, $8.1 \%$ for the female sample and $18.4 \%$ for male sample.

Results obtained when we applied the Wilcoxon test for paired samples to study the differences between the results of the Tandem walking test are shown in Table 17. When true acupuncture was done, the results before and after treatment were statistically significant for the whole sample, and when we considered males and females separately. Also, the results before and after treatment with sham acupuncture were statistically significant for the whole sample and for male sample, but not for female sample.

Table 17: Results of the Wilcoxon test applied to the analysis of Tandem walking results

\begin{tabular}{|c|c|c|}
\hline & True acupuncture & Sham acupuncture \\
\hline $\mathrm{N}=20$ & Before vs After & Before vs After \\
\hline Significance & $0.001^{*}$ & $0.006^{*}$ \\
\hline $\begin{array}{c}\text { Male sample } \\
\mathrm{N}=8\end{array}$ & Before vs After & Before vs After \\
\hline $\begin{array}{c}\text { Significance } \\
\text { Female sample } \\
\mathrm{N}=12\end{array}$ & $0.012^{*}$ & $0.017^{*}$ \\
\hline Before vs After & Before vs After \\
*: Statistically significant & $0.018^{*}$ & 0.176 \\
\hline
\end{tabular}

\subsection{MSWS12 test}

It was asked to all patients to answer the survey Multiple Sclerosis Walking Scale 12. But in some cases, we only have the answers before and after the first acupuncture treatment (true or sham, depending on the group) and after the second treatment of the patient. Due to these conditions, in the present work the results of the MSWS12 test will not be considered. Nevertheless, based on the obtained answers to the test, a general patients' perception of improvement of symptoms after the true acupuncture treatment was reported. Some patients reported more mobility, more energy and also less spasms in the day after the treatment what improved their daily life. 
Effects of Acupuncture on Gait of Patients with Multiple Sclerosis 
4. DISCUSSION 
Effects of Acupuncture on Gait of Patients with Multiple Sclerosis 
Clinical manifestations of MS present a great variability and are unpredictable, most of them representing causes of disability that lead to severe difficulties in the daily life of these patients. Although there are no clinical findings that are unique to MS, some of them are highly characteristic of the disease: vision problems, fatigue, weakness, pain, spasticity are among them (National Sclerosis Society, 2014). Among these clinical manifestations of MS, gait dysfunction represents one of the most debilitating symptoms experienced by patients with $85 \%$ of them reporting gait impairment as a major limitation of their lives, as was previously referred (LaRocca, 2011).

Gait is a complex process involving coordination of multiple systems of the body. Thus, several factors, such as weakness and spasticity from pyramidal lesions, loss of coorientation from dorsal column, and cerebellar lesions, together with visual and cognitive dysfunction, pain, and also environmental and personal factors can contribute to walking disability (Pearson et al, 2004).

One of the priorities managing with MS is to define strategies to control the symptoms and to prevent secondary complications and increased disability associated with the disease. Also, it must take into account that the resulting limitations of the disease are associated with strong social and economic impacts. Symptomatic treatment must be carefully planned and suitable for each patient as there are possible interactions between treatments for specific symptoms. Different pharmacological and non-pharmacological approaches may be included, but they always need the active involvement of the patient. A reduction of the symptoms not only improves the quality of life of the patients but also makes them more active and more involved in the treatment (Pope, 2007).

Acupuncture has a wide range of possible applications and may be able to contribute to the management of some of the symptoms in patients with MS. Moreover, in general, side effects from acupuncture are low. It therefore represents a useful therapeutic option to consider within the overall management of individuals with MS. Scientific literature regarding the application of acupuncture in neurological diseases has reported reduction of pain, numbness and tingling (Schroder et al, 2007; Rapson el al, 2003); significant improvement in sensory and motor function (Wong et al, 2003); less spasticity (Liu et al, 2008); enhanced motor function (Chae et al, 2009); and significant improvement in fatigue (Martin et al, 2006; Vickers et al, 2004). However, literature regarding gait impairment is scarce, and therefore additional studies using appropriated outcome measures are required. 
Taking this into account, the present study of acupuncture treatment, according to the Heidelberg model of TCM, was designed to investigate if acupuncture can be a useful therapeutic option in patients with gait impairment in multiple sclerosis of relapse-remitting type. To achieve this goal a sample of 20 patients was analysed.

Regarding the characterization of the sample, we found a ratio female/male of 1.5 , which is in agreement with what was reported in other studies (Ascherio et Munger, 2007). Also, differences in the mean age between males and females were found, with a mean age of females (50.9) higher than the mean age for males (39.3). In relation to the age at diagnosis, we also observed differences: 40.1 years for females and 27.4 years for males. This data does not differ from those reported in the outpatient clinic of Braga Hospital with 235 patients enrolled (Figueiredo et al. 2012), suggesting that although our sample is small, 20 individuals, it is representative of the MS population in Portugal.

The patients of our sample were divided into two randomized groups. Each patient received in a first moment one acupuncture treatment (true or sham acupuncture) and in a second moment the other treatment. Thus, our results refer to paired samples. The time interval between the first and the second treatment was, at least, of two weeks. This period of time is important to avoid that results from the first treatment interfere in the second one.

According to the Heidelberg model of Traditional Chinese Medicine, the pathogenesis of MS involves lack of fluids, Yin and Yang deficiency and labile Qi, with the presence of stage II, VI and I of ALT. This model was used to select the points for acupuncture treatments. Thus, the selected points for true acupuncture - S34 (ST34), V40 (BI40) and V57(BI57) - are believed to have an effect directed to produce an increasing of Qi and Xue flow in lower limbs. They are used in cases of Yin and also Yang deficiency with the presence of ventus internus, and they are also considered to be important to dispel humor (Greten, 2012). Sham acupuncture was administered away of those points. Frequent problems in research of acupuncture have to do with finding an adequate control group (Hopwood, 2004) and distinguish how much of the total effect may be represented by the associated context/spontaneous effects and how much is attributable to the effect of the therapy. In this context the use of paired samples offers the benefit of controlling extraneous factors that can influence the results.

For the evaluation of the treatment in terms of gait improvement, we used the 25-Foot test. Although assessing gait disability is of great importance in some pathology including 
MS, there is no consensus regarding the most appropriate tool for characterization of gait dysfunction (Kieseier and Pozzilli, 2012). Timed walking over a fixed distance has been extensively used as a clinical measure of gait in a variety of neurological conditions and forms part of a recommended outcome measure for clinical trials in multiple sclerosis (Fisher et al, 1999). In the present study we used the T25FW, the most common of timed performance tests. It represents a good measure of overall walking ability and is suited for use in clinical setting (Gijbels et al, 2012). In this sense, the results obtained in the present study can support the idea that the T25FW test is sufficiently sensitive to changes that occurred as a result of treatment and can therefore be a useful tool as a clinical measure of gait in studies involving acupuncture. This is an important aspect as well designed research is required to guide practice more effectively, and appropriated outcome measures (objective and measurable parameters) need to be carefully considered in order to contribute to the credibility of the effectiveness of acupuncture treatments.

With respect to the evaluation of the acupuncture treatments, our results reveal a statistically significant reduction in the time spent to perform the 25-Foot test with true acupuncture treatment when compared to sham acupuncture. These observations must be confirmed in future larger trials, but our results produce evidences that the treatment protocol used in our study for true acupuncture is more effective in improving gain impairment than sham acupuncture. When we observed the percentages of improvement, we found a mean improvement value of the order of $14 \%$. When analysing the results by gender, it seems that the effect of true acupuncture is stronger in females than in males. When we observed the main complains of female sample, disbalance and tiredness are the main ones, while males present more variability. We cannot forget that several factors influence the individual gait and it is important to remind that TCM diagnosis and treatment is based on a different understanding of illness and health from Western medicine. Although for acupuncture research standardized protocols are necessary, in fact, acupuncture treatments have to be individualized to the patient's underlying situation.

When using the tandem walking method to evaluate the effectiveness of acupuncture, we found statistically significant differences between the time spent to perform the test before and after the treatment in both, true acupuncture and sham acupuncture, for the whole sample and for male sample, but not for female sample. Walking in a straight line using tandem gait brings out abnormalities in gait and balance. As mentioned previously, the females of our sample seem to be more affected by disbalance than males, and this fact can influence the results. Also, our results seem to point to the possibility that balance may depend more on individual motivation or expectations. 
According to Xia et al (2010) the physiological effects of needling, the distance from the classical acupuncture points, as well as a wide range of neurophysiological and neurochemical responses, such as the release of neurotransmitters or activation of segmental and heterosegmental antinociceptive system, or, the placebo effects, are considered to be involved in the improvement of symptoms observed with sham acupuncture in some studies. In fact, the placebo effect remains an interesting topic of research. Recently, a systematic review estimated the percentage of responders after various placebo interventions in studies assessing prophylactic treatment for migraine. The authors reported that after oral, pharmacologic placebos, $22 \%$ of the patients reported an attack frequency reduction greater than $50 \%$ and that after sham acupuncture this percentage was 38\%. (Craen, 2014).

The comparison of our results with those of literature, revealed to be a difficult task because of the lack of studies regarding gait and acupuncture in MS. In a recent review (Karpatkin et al, 2014) including all studies that used acupuncture to treat any symptom of MS or to evaluate disease activity, fifteen articles were found, and none of them specifically examined mobility measures such as gait or balance. Five studies examined the effect of acupuncture in quality of life, three looked for the effects of acupuncture on MS fatigue, two examined the effect of acupuncture in MS spasticity, two examined the effect of acupuncture in MS pain and three were animal studies.

The results obtained in the majority of papers regarding MS symptoms point in general to beneficial effects of acupuncture. Also, in another review concerning the use of complementary therapies in MS, including acupuncture (Esmonde and Long, 2008), MS patients described it as generally relaxing, but also a treatment which increased their energy and feelings of well-being. More specifically, they said it reduced pain, increased flexibility, improved balance and reduced recovery time from relapses. Nevertheless, not all the studies show that acupuncture had a meaningful impact on MS. This can be explained by the fact that many of the studies are case reports, and others have no randomization, adequate measures, poor statistics and little use of controls (Karpatkin et al, 2014).

Given the individualized nature of acupuncture treatment, according to TCM, and the multifactorial nature of MS, creating appropriated research protocols can be particularly challenging (Karpatkin et al, 2014). Individualized acupuncture treatments, contrarily to the standard treatments used in randomized clinical trials, the fact that placebo response 
cannot be neglected and that acupuncture is a complex intervention in physiological terms, makes that it does not fit easily into conventional drug trial format. To our knowledge, this is the first controlled clinical trial on the effects of acupuncture on gait problems in MS patients. Although our results must be interpreted carefully, mainly due to small sample size, we found consistent improvement on mobility in patients with MS of relapse-remitting type when true acupuncture treatment was used, relative to sham acupuncture.

In summary, our study protocol provides evidence that acupuncture treatment, according to Heidelberg model of TCM, can result in improvements in mobility in MS population and consequently improvement in their quality of life. Of course, larger studies are needed to confirm the clinical and cost-effectiveness of acupuncture treatment, but our results suggest that acupuncture can be an attractive option for intervention for MS patients with gait impairment symptoms looking for an effective therapy. 
Effects of Acupuncture on Gait of Patients with Multiple Sclerosis 
5. CONCLUSSIONS 
Effects of Acupuncture on Gait of Patients with Multiple Sclerosis 
From the results obtained in the present study we can conclude:

1- The T25FW test is sufficiently sensitive to changes that occurred as a result of treatment and so can be a useful tool as a clinical measure of gait in studies involving acupuncture.

2- The Tandem walking test results can possible indicate that balance may depend more on individual motivation or expectations.

3- True acupuncture protocol used is more effective in improving gain impairment than sham acupuncture, suggesting a specific effect of true acupuncture protocol.

4- Possible differences in factors influencing gait problems can be involved in differences in improvement observed between females and males, what may indicates the importance of TCM diagnostic and individualized acupuncture treatments according to it.

5- Acupuncture treatment, according to the Heidelberg model of TCM, can result in improvements in mobility in MS population and consequently improvement in their quality of life.

6- Acupuncture can be an attractive option for intervention for patients with MS of relapseremitting type with gait impairment symptoms looking for an effective therapy. 
Effects of Acupuncture on Gait of Patients with Multiple Sclerosis 


\section{REFERENCES}


Effects of Acupuncture on Gait of Patients with Multiple Sclerosis 
Alves D (2010) Neurofisiologia. In: Introdução à Esclerose Múltipla. Grupo de Estudos da Esclerose Múltipla. Sociedade Portuguesa de Neurologia.

Ascherio A, Munch KL (2007) Environmental risk factors for multiple sclerosis. Part I: The role of infection. Ann Neurol 61(4) 288-99.

Ascherio A, Munger K (2007) Environmental risk factors for multiple sclerosis. Part I: the role of infection. Ann Neurol 61:288-299.

Bach F (2002) The effect of infectious on susceptibility to autoimmune and allergic diseases. N Engl J Med 347: 911-920.

Barkhof F, Rocca M, Francis G et al (2003) Early Treatment of Multiple Sclerosis Study Group. Validation of diagnostic magnetic resonance imaging criteria for multiple sclerosis and response to interferon beta1a. Ann Neurol 53:718-724.

Batista S, Sargento J, Sousa L (2010) Tratamento imunomodulador. In: Introdução à Esclerose Múltipla. Grupo de Estudos da Esclerose Múltipla. Sociedade Portuguesa de Neurologia.

Bigotte de Almeida L. Esclerose Múltipla: A história de um longo enigma. In: Introdução à Esclerose Múltipla (2010). Grupo de Estudos da Esclerose Múltipla. Sociedade Portuguesa de Neurologia.

Blackwell R, McPherson H (1993) Multiple sclerosis staging and patient management. J Clin Med 42(5):12.

Bolaños-Jiménez R, Arizmendi-Vargas J, Carrillo-Ruiz J D, López-Lizárraga ME, Calderón Álvarez-Tostado JL, Martínez-Menchaca H, Leyva Resendiz I, Serrato-Ávila JL, Rendón-Molina A, Rivera-Silva G (2011). Journal of Neuroscience and Behavioural Health 3: 44-50.

Boz C, Ozmenoglu M, Velioglu S, Kilinc K, Orem A, Alioglu Z, Altunayoglu V (2006) Matrix metalloproteinase-9 (MMP-9) and tissue inhibitor of matrix metalloproteinase (TIMP-1) in patients with prolapsing multiple sclerosis treated with interferon beta. Clin Neurol Neurosurg 108(2): 124-128. 
Burke D, Kierman MC, Bostock H (2001) Excitability of human axons. Clin Neurophysiol 112:1575-85.

Calabrese P (2006) Neuropsychology of multiple sclerosis- an overview. J Neurol 253 Suppl 1:10-15.

Cerqueira NF (2004) Medicina no ocidente e na China: uma abordagem filosófica. Botucatu: Universidade Estadual Paulista.

Chae Y, Lee H, Kim H (2009) Parsing brain activity associated with acupuncture treatment in Parkinson's disease. Mov Disord 24(12): 1794-1802.

Chandran S, Hunt D, Joannides A, Zhao C, Compstom A, Franklin RJ (2008) Myelin repair: the role of stem and precursor cells in multiple sclerosis. Philos Trans $\mathrm{R}$ Soc Lond B Biol Sci 363:171-183.

Chen CJ, Tsai WC, Yen JH, Tsai JJ, Ou TT, Lin CC, Liu HW (2001) Bloodletting acupuncture of the engorged vein around $\mathrm{BI}-40$ (wei-chung) for acute lumbar pain. Am $\mathrm{J}$ Chin Med 29(3-4):387-91.

Comi G, Filippi M Wolinsky JS (2001) European/Canadian multicentre, double-blind, randomized, placebo-controlled study of the effects of glatiramer acetate on magnetic resonance imaging-measured disease activity and burden in patients with relapsing multiple sclerosis. European/Canadian Glatiramer Acetate study group. Ann Neurol 49:290-297.

Compston A, Coles A (2008) Multiple Sclerosis. Lancet 372:1502-17.

Confavreux C, Vukusic S, Adeaide P (2003) Early clinical predictors and progression of irreversible disability in multiple sclerosis: an amnesic process. Brain 126:770-782.

Craen AJ (2014) The placebo effect: is the wish father to the thought? Ned Tijdschr Geneeskd 158: A7466.

DasGupta R, Foewler CJ (2002) Sexual and urological dysfunction in multiple sclerosis: better understanding and improve therapies. Curr Opin Neurol 15:271-278. 
De Jager PL, Simon KC, Munger KL, Rioux JD, Hefler DA, Ascherio A (2008) Integrating risk factors: HLA-DRB1*1501 and Epstein-Barr virus in multiple sclerosis. Neurology 70(13Pt2):113-118.

De Sá J, Alcalde Cabero E, Amazán Isla J, Sempere A, Cuesta J. (2012) Capturerecapture as a potentially useful procedure for assessing prevalence of multiple sclerosis:methodologic exercise using portuguese data. Neuroepidemiology 38:209-216.

De Sá J, Paulos A, Mendes H, Becho J, Marques J, Roxo J(2006) The prevalence of multiple sclerosis in the district of Santarem, Portugal. J Neurol 253:914-918.

De Sèze M, Ruffion A, Denys P (2007). The neurogenic bladder in MS: review of the literature and proposal of management guidelines. Mult Scler 13(7): 915-928.

Dutta R, McDonough J, Yin X, Peterson J, Chang A, Tores T, Gudz T (2006) Mitochondrial dysfuntion as a cause of axonal degeneration in multiple sclerosis patient. Ann Neurol 59:478-489.

Elian M, Nightingale S, Dean G (1990) Multiple Sclerosis among United Kingdom-born children of immigrants from the Indian subcontinent, Africa and West Indies. J Neurol Neurosurg Psychiatry 53: 906-11.

Esmonde L, Long AF (2008) Complementary therapy use by persons with multiple sclerosis: Benefits and research priorities. Complement Ther Clin Pract 14(3):176-184.

European Multiple Sclerosis Platform. www.emsm.org/multiple-sclerosis (Accessed May 30, 2014).

Farias AS, Pradella F, Schmitt A, Santos LMB, Martins-de-Souza D (2014) Tem years of proteomics in multiple sclerosis. Proteomics 14: 467-480.

Fisher JS, Rudick RA, Cutter GR, Reingold SC (1999) The Multiple Sclerosis Functional Composite Measure (MSFC): an integral approach to MS clinical outcome assessment. National MS Society Clinical Outcomes Assessment Task Force. Mult Scler 5:244-250. 
Fontoura P (2010) Fisiopatologia da Esclerose Múltipla. In: Introdução à Esclerose Múltipla (2010). Grupo de Estudos da Esclerose Múltipla. Sociedade Portuguesa de Neurologia.

Foong J, Ron MA (2003) Neuropsychiatry; cognition and mood disorders. In McDonald IW, Noseworthy Ed Blue Books of practical neurology. Butterworth-Heinemann. Philadelphia.

Freitas J, Batista S, Diogo Sousa L (2010) Terapêuticas emergentes na esclerose múltipla. In: Introdução à Esclerose Múltipla. Grupo de Estudos da Esclerose Múltipla. Sociedade Portuguesa de Neurologia.

Gijbels D, Dalgas U, Romberg A et al (2012) Which walking capacity tests to use in multiple sclerosis? A multicentre study providing the basis for a core set. Mult Scler 18:364-371.

Gijbels D, Eijnde B, Feys P (2011) Comparison of the 2-and 6- minute walk test in multiple sclerosis. Mult Scler 17:1269-1272.

Goldman MD, Marrie RA, Cohen JA (2008) Evaluation of the six-minute walk in multiple sclerosis subjects and healthy controls. Mult Scler 14(3):383-390.

Greenstein J (2007) Current concepts of the celular and molecular pathophysiology of multiple sclerosis. Develop Neurobiol 67: 1248-1265.

Greim B, Benecke R, ZettI UK (2007) Qualitative and quantitative assessment of fatigue in multiple sclerosis (MS). J Neurol 254(2): 1158-64.

Greten HJ (2010) Understanding TCM, scientific Chinese medicine - the Heidelberg model. Preliminary unrevised course version. $5^{\text {th }}$ edition.

Greten HJ (2012) Understanding acupoints. Scientific Chinese Medicine. The Heidelberg model. Heidelberg School Editions (unrevised course version).

Greten, HJ (2007). Kursbuch Traditionelle Chinesische Medizin. Thieme. 
Guan-Yuan J, Jia-Jia X, Louis L. (2006). Contemporary Medical Acupuncture-a system approach. Higher Education Press.

Haensch CA, Jorg J (2006) Autonomic dysfunction in multiple sclerosis. J Neurol 253. Suppl1: 13-19.

Hartrich L, Weinstock-Guttman B, Hall D, Badgett D, Baier M, Patrick K, Feichter J, Hong J, Ramanathan M (2003) Dynamics of imune cell traficking in interferon-beta treated multiple sclerosis patients. J Neuroimmunol 39(1-2): 84-92.

Hemper H, Chow V (2006) Porket Atlas of Acupuncture. Ed Thieme.

Hobart JC, Riazi A, Lamping DL, Fitzpatrick R, Thompson AJ (2003) Measuring the impact of MS on walking ability: the 12-item MS Walking Scale (MSWS-12). Neurology $60(1): 31-36$.

Holmes S, Friese MA, Siebold C, Jones EY, Bell J, Fugger L (2005) Multiple sclerosis: MHC associations and therapeutic implications. Exp Rev Mol Med 7:1-17.

Hopwood V (2004) Acupuncture trials and methodological considerations. Acupuncture in Physiotherapy. Oxford: Butterworth Heinemann.

Hopwood V, Donnellan C (2010) Acupuncture in neurological conditions. Churchill Livingston Elsevier.

Iwakura Y, Ishigame H (2006) The II-23/II-17 axis in infalammation. J Clin Invest 116(5): 1218-1222.

Izquierdo G, Ruiz-Peña JL (2003) Evaluación clínica de la esclerosis múltiple: cuantificación mediante la utilización de escalas. Rev Neurol 36:145-152.

Jonhson KP, Brooks BR; Ford CC (2000) Copolymer 1 Multiple Scleroses Group. Sustained clinical benefits of glatiramer acetate in relapsing multiple sclerosis patients observed for 6 years. Mult Scler 6:255-266.

Kanchandani R, Howe JG (1982) Lhermitte's sign in multiple sclerosis: a clinical survey and review of literature, J Neurol Neurosurg Psychiatry 45:308-312. 
Kappos L, Antel J, Comi G, Montalban X, O'Connor P, Polmam CH, Haas T, Kom AA, Karlson G, Radue EW, FTY720 D2201 Study Group (2006) Oral Fingolimod (FTY720) for relapsing multiple sclerosis. N Engl J Med 355(11):1124-40.

Kazatchkine MD, Kaveri SV (2001) Immunomodulation of autoimmune and inflammatory diseases with intravenous immune globulin. N Engl J Med 354:747-755.

Kebir H, Kreymborg K, Ifergan I (2007) Human $\mathrm{T}(\mathrm{H}) 17$ lymphocites promote blood-brain barrier disruption and central nervous system inflammation. Nat Med 13:1173-75.

Kelleher KJ, Spense W, Solomonidis S, Apatsidis D (2010) The characterisation of gait pattern of people with multiple sclerosis. Disabil Rehabil 32(15) 1242-1250.

Kieseir BC, Pozzilli C 82012) Assessing walking disability in multiple sclerosis. Mult Scler 18(7): 914-924.

Korn T, Reddy J, Gao W (2007) Myelin specific regulatory T cells accumulate in the CNS but fail to control autoimmune inflammation. Nat Med 13:423-431.

Kujala P, Portin R, Ruutiainen J (1997) The progress of cognitive decline in multiple sclerosis after four years follow up. Brain 120:289-297.

Kurtzke JF (1977) Geography in multiple scerosis. J Neurol 215: 1-26.

Kurtzke JF. Rating Neurological impairment in multiple sclerosis: an expanded disability status scale (EDSS). Neurology 1983; 33: 144452.

LaRocca NG (2011) Impact of walking impairment in multiple sclerosis: perspectives of patients and care partness. Patient 4(3): 189-201.

Lemire JM, Archer DC, Beck L, Spiegelberg HL (1995) Immunosupressive actions of 1,25dihydroxyvitamin D3: preferential inhibition of Th1 functions. J Nutr 125(suppl 6):1704S1708 S.

Liu W, Mukherjee M, Sun C (2008) Electroacupuncture may help motor recovery in chronic stroke survivors: a pilot study. J Rehabil Res Dev 45(4): 587-95. 
Lu F, Selak M, O'Connor J, Croul S, Lorenzana C, Butunoi C, Kalman B (2000) Oxidative damage to mitochondrial DNA and activity of mitochondrial enzymes in chronic active lesions of multiple sclerosis. J Neurol Sci 177:95-103.

Lu JP, Cui YL, Shi RH (eds) (1990) Chinese Acupuncture and Moxibustion. Publishing House of Shanghai. College of Traditional Chinese Medicine.

Lublin FD, Reingold SD (1996) Defining the clinical course of multiple sclerosis: results of an international survey. National Mutiple Sclerosis Society (USA) Advisor Committee on Clinical Trials on new agents in Multiple Sclerosis. Neurology 46:907-911.

Lucchinetti CF, Popescu BFG, Bunyan RF (2011) Inflammatory cortical demyelination in early multiple sclerosis. N Engl J Med 365: 2188-2197.

Maddestra M, Sabbatini S, Paci F, Paci A (1998) Epidemiological survey in the province of Terni. Arch Neurol 17:54.

Martin CL, Philips BA, Kilpatrick TJ et al (2006) Gait and balance impairment in early multiple sclerosis in the absence of clinical disability. Mult Scler 12(5):620-628.

Martin DP, Sletten CD, Williams BA, Berger IH (2006) Improvement in fibromyalgia symptoms with acupuncture: results of a randomized controlled trial. Mayo Clin Proc 81(6):749-57.

Mateus MC (2010) Contributos para a avaliação dos medicamentos em Portugal. Tese de doutoramento. Escola Nacional de Saúde Pública. Universidad Nova de Lisboa. Lisbon. Portugal.

McGuigan C, Hutchinson M (2004) Confirming the validity and responsiveness of the Multiple Sclerosis Walking Scale-12 (MSWS-12). Neurology 62(11): 2103-2105.

Micu I, Jiang Q, Coderre E, Ridsdale A, Zang L, Woulfe J, Yin X (2006) NMDA receptors mediate calcium accumulation in myelin during chemical ischemia. Nature 439; 988-992.

Multiple Sclerosis Association of America. www.mymsaa.org/about-ms/overview/ (Accessed May 30, 2014). 
Munger KL, Zhang SM, O'Reilly E, Hernán MA, Olek MJ, Willett WC, Ascherio A (2004) Vitamin D intake and incidence of multiple sclerosis. Neurology 62:60-65.

National Multiple Sclerosis Society. Symptoms and diagnosis. http://www.nationalmssociety.org/Symptoms-Diagnosis/Clinically-Isolated-Syndrome(CIS). Accessed August 30, 2014.

National Multiple Sclerosis Society. Symptoms and diagnosis. http://www.nationalmssociety.org/Treating-MS/Managing-Relapses. Accessed September 8, 2014.

Nguyen VN (2011) Medicina Tradicional Chinesa-Acupunctura-Moxibustion-Massagens. $\left(1^{\text {st }}\right.$ ed). Ed Roca.

NIH Consensus Conference on Acupuncture (1998) JAMA 280(17):1518-24.

Nogueira LAC, Baitelli C, Avarenga RMP, Thuler LCS (2012) Tradução e adaptação transcultural da Multiple Sclerosis Walking Scale-12(MSWS-12) para a língua portuguesa do Brasil. Cad Saude Pública, Rio de Janeiro 28(5):998-1004.

Nortvedt MW, Riise T, Frugard J (2007) Prevalence of bladder, bowel and sexual problems among multiple sclerosis patients two to five years after diagnosis, Mult Scler 13(1):106-112.

O`Connor AB, Schwid SR, Hermann DN, Markman JD, Dworkin RH (2008) Pain associated with multiple sclerosis: Systematic review and proposed classification. Pain 58 : 89-93.

Olek MJ (2014) (http://www.uptodate.com/contents/clinical-features-of-multiple-sclerosidin-adults) Accessed August 30, 2014.

Pais I (2013) Efeito da acupunctura nas células NK em dioentes com cancro colorectal submetidos a quimioterapia. Estudo prospectivo, randomizado e controlado. Master Thesis in Traditional Chinesse Medicine. ICBAS. Porto. Portugal.

Pearson OR, Busse ME, van Deursen RWM, Wiles CM (2004) Quantification of walking mobility in neurological disorders. Q J Med 97:463-475. 
Pedrosa R (2010a) Imagiologia. In: Introdução à Esclerose Múltipla. Grupo de Estudos da Esclerose Múltipla. Sociedade Portuguesa de Neurologia.

Pedrosa R (2010b) Tratamento dos surtos. In: Introdução à Esclerose Múltipla. Grupo de Estudos da Esclerose Múltipla. Sociedade Portuguesa de Neurologia.

Pilutti L, Dlugonski D, Sandroff B, Suh Y, Pula J, Sosnoff J, Motl R (2013) Further validation of multiple sclerosis walking scale-12 scores based on spatiotemporal gait parameters. Archives of Physical Medicine and Rehabilitation 94:575-578.

Ping L (2002) El gran libro de la medicina china. Ediciones Planeta, Madrid.

Pinheiro J, Guimarães J (2011) "Esclerose Múltipla-conhecer e desmitificar. Apresentação na Secção regional da Ordem dos Médicos. Porto, 23 Março, 2011.

Pinto Marques J (2010) EM-Formas/Fases da doença. In: Introdução à Esclerose Múltipla. Grupo de Estudos da Esclerose Múltipla. Sociedade Portuguesa de Neurologia.

Piras MR, Solinas G (2003) Longitudinal study of cognitive dysfunction in multiple sclerosis. Neurol Neurosurg Psychiatry.

Pollmann W, Feneberg W (2008) Current management of pain associated with multiple sclerosis. CNS Drugs 22(4): 291-324.

Polman $\mathrm{CH}$, Reingold SC, Banwell B, Clanet M, Cohen JA, Filippi M, Fujihara K, Havrdova E, Hutchinson M, Kappos L, Lublin FD, Montalban X, O'Connor P, SandbergWollheim M, Thompson AJ, Waubant E, Weinshenker B, Wolinsky JS (2011) Diagnostic criteria for multiple sclerosis: 2010 revisions to the McDonald criteria. Ann Neurol 69(2):292-302.

Pope PM (2007) Severe and complex neurological disability: management of the physical condition. Ediburgh: Elsevier.

Porkert M, Hempen CH (1995). Classical Acupuncture. The standard book. Phainon, Germany. 
Proceedings of the EPMA World Congress. EPMA Journal 2014, Volume 5 Suppl http://www.epmajournal.com/supplement/5/S1 (Accessed May 30, 2014).

Pugliatti M, Rosati G, Carton H, Riise T, Drulovic J, Vecsei L, Moilanov I (2006). The epidemiology of multiple sclerosis in Europe. Eu J Neurol 13:700-722.

Qiu Mao L. (2001). Acupunctura Chinesa e Moxibustão. $1^{\text {st }}$ ed, Ed. Roca.

Rapson LM, Wells N, Pepper J (2003) Acupuncture as a promising treatment for below level central neuropathy pain: a retrospective study. J Spinal Cord Med 26(1): 21-6.

Rodriguez M, Miller DJ (1994) Immune promotion of central nervous system remyelination. Prog Brain Res 103:343-355.

Ruth AM (2004) Environmental risk factors in multiple sclerosis aetiology. Lancet Neurol 3:709-718.

Sá A (2010a) Critérios de diagnóstico da Esclerose Múltipla. In: Introdução à Esclerose Múltipla. Grupo de Estudos da Esclerose Múltipla. Sociedade Portuguesa de Neurologia.

Sá MJ (2010b) Estudo do LCR e marcadores biológicos. In: Introdução à Esclerose Múltipla. Grupo de Estudos da Esclerose Múltipla. Sociedade Portuguesa de Neurologia.

Sadovnick AD, Dyment DA, Ebers GC, Risch NJ (1996) Evidence for genetic basis of multiple sclerosis. Lancet 347: 1728-1730.

Saghaei M, Razavi S (2001) Bloodletting acupuncture for the prevention of strider in children after tracheal extubation: a randomised, controlled study. Anaesthesia 56:961964.

Sandroff BM, Sosnoff JJ, Motl RW (2013) Physical fitness, walking performance and gait in multiple sclerosis. J Neurol Sci 328(1-2):70-76.

Santos MJ (2012) The effects of "Heidelberg sclap acupuncture" on obstructive sleep apnea. A preliminary study. Master Thesis in Traditional Chinesse Medicine. ICBAS. Porto. Portugal. 
Sawcer S (2006) A new era in the genetic analysis of multiple sclerosis. Curr Opin Neurol 19:237-241.

Schroder S, Liepert J, Rempis A, Greten HJ (2007) Acupuncture treatment improves nerve conduction in peripheral neuropathy. Eu J Neurol 14:276-81.

Schwid SR, Goodman AD, McDermott MP, Bever CF, Cook SD (2002) Quantitative functional measures in MS: what is a reliable change?. Neurology 58:1294-1296.

Seca, SMF (2011). Efeitos agudos da acupunctura na dor lombar crónica Estudo preliminar, prospectivo, randomizado, controlado e cego. Master Thesis in Traditional Chinesse Medicine. ICBAS. Porto. Portugal.

Shapiro S, Galboiz Y, Lahat N, Kinarty A, Miller A (2003) The immunological-synapse at its APC side in relapsing and secondary progressive multiple sclerosis: modulation by interferon beta. J Neuroimmunol 144(1-2): 118-124.

Silva A (2012) Função cognitiva na Esclerose Múltipla. Revista da TEM 2: 8-11.

Snook EM, Molt RW (2009) Effect of exercise training on walking mobility in multiple sclerosis: a meta-analysis. Neurorehabil Neural Repair 23(2):108-116.

Socie MJ, Sosnoff JJ (2012) Gait variability and multiple sclerosis. Multiple Sclerosis International 2013.

Sorensen PS (2003) The role of intravenous immunoglobulin in the treatment of multiple sclerosis. J Neurol Scien 206:123-130.

Sosnoff JJ, Weikert M, Dlugonski D, Smith DC, Motl RW (2011a) Quantifying gait impairment in multiple sclerosis using GaitRite technology. Gait Posture 34(1):145-147.

Sosnoff JJ, Gappmaier E, Frame A, Molt RW (2011b) Influence of spasticity on mobility and balance in persons with multiple sclerosis. J Neurol Phys Ther 35(3):129-132.

Sosnoff JJ, Sandroff BM, Motl RW (2012) Quantifying gait abnormalities in persons with multiple sclerosis with minimal disability. Gait Posture 36(1):154-156. 
Spain RI, George RJ, Salarian A, Mancini M, Wagner JM, Horak FB, Bordette D (2012). Body-worn motion sensors detect balance and gait deficits in people with multiple sclerosis who have normal walking speed. Gait \&Posture 35(4):573-578.

Stergion N, Harbourne R, Cavanaugh J (2006) Optimal movement variability: a new theoretical perspective for neurologic physical therapy. J Neurol Phys Therapy 30(3): 120129.

Stys PK (2004) White matter injury mechanisms. Curr Mol Med 4:109-126.

Thacker EL, Mirzaei F, Ascherio A (2006) Infectious mononucleosis and risk for multiple sclerosis: a meta-analysis. Ann Neurol 59:499-503.

The International Multiple Sclerosis Genetics Consortium (2007) Risk alleles for multiple sclerosis identified by Genomewide study. N Engl J Med 357.

Thoumie P, Lamotte D, Cantalloube S Faucher M, Amarenco G (2005) Motor determinants of gait in 100 ambulatory patients with multiple sclerosis. Mult Scler 11(4):485-491.

Tullman MJ, (2013) Overview of the epidemiology, diagnosis, and disease progression associated with Multiple Sclerosis. Am J Manag Care 19:S15-S20.

Tzartos JS, Friese MA, Craner MJ (2008) Interleukin-17 production in central nervous system-infiltrating $T$ cells and glial cells is associated with active disease in multiple sclerosis. Am J Pathol 172:146-55.

Uria DF, Calatayud MT, Virgala P (1997) Multiple Sclerosis in Gijon health district, Asturias, northern Spain. Acta Neurol Scand 96:577-581.

Vale J (2010) Esclerose Múltipla: manifestações clínicas. In: Introdução à Esclerose Múltipla (2010). Grupo de Estudos da Esclerose Múltipla. Sociedade Portuguesa de Neurologia.

Van der Mei IA, Ponsoby AL, Dwyer T (2003) Past exposure to sun, skin phenotype and risk of multiple sclerosis: a case control study. BMJ 327: 316-321. 
Veloso M (2010) Epidemiologia da Esclerose Múltipla. In: Introdução à Esclerose Múltipla (2010). Grupo de Estudos da Esclerose Múltipla. Sociedade Portuguesa de Neurologia.

Vickers AJ, Straus DJ, Fearon B, Cassileth BR (2004) Acupuncture for poschemotherapy fatigue: a phase II study. J Clin Oncol 22(9): 1731-5.

Weinshenker BG. (1996) Clinical outcome measures for multiple sclerosis. In Goodkin ED, Rudick RA, eds. Multiple sclerosis. London: SpringerVerlag.

WHO (2001) International Classification of Functioning. Disability and Health: ICF Geneva, World Health Organization.

WHO (2002) Acupuncture: review and analysis of reports on controlled clinical trials. Geneva: World Health Organization.

WHO (2010) Benchmarks for training in traditional/complementary and alternative medicines: benchmarks for training in traditional Chinese medicine. WHO Library Cataloging-in-Publication Data.

WHO Consultation on Acupuncture (1996) 28 October - 1 November. Cervia, Italy.

Winter DA (2009) Biomechanics and motor control of human movement. John Wiley \& Sons, Hoboken, NJ USA, $4^{\text {th }}$ ed.

Wong AM, Leong CP, Su TY (2003) Clinical trial of acupuncture for patients with spinal cord injuries. Am J Phys Med Rehabil 82(1): 21-27.

Xia Y, Cao X, Wu G, Cheng J (2010) Acupuncture Therapy for Neurological Diseases: A neurobiological View. Tsinghua University Press, Beijing and Springer Verlag Berlin Heidelberg. 
Effects of Acupuncture on Gait of Patients with Multiple Sclerosis 
7. ANNEXES 
Effects of Acupuncture on Gait of Patients with Multiple Sclerosis 
ANNEX 1 

Ao $\mathrm{C} /$ do Prof. Doutor Jorge Pereira Machado,

A SPEM - Sociedade Portuguesa de Esclerose Múltipla - Delegação Distrital aceita colaborar na realização do estudo intitulado "Estudo do possível efeito de tratamentos de medicina tradicional chinesa (MTC) na qualidade de vida e sintomas de doentes com esclerose múltipla (EM) " pela Maria Begonã Criado, aluna do mestrado em Medicina Tradicional Chinesa do ICBAS - Universidade do Porto.

Com os melhores cumprimentos,

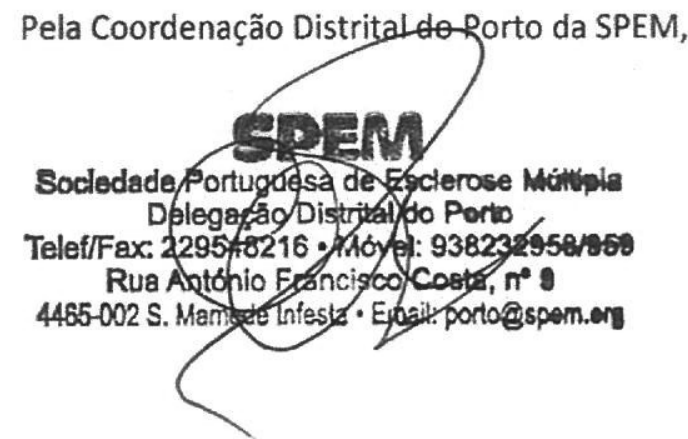



Comissão de Coordenação de MTC Instituto de Ciências Biomédicas Abel Salazar

Universidade do Porto

Rua de Jorge Viterbo Ferreira n. ${ }^{\circ} 228$

4050-313 Porto

Assunto: Colaboração no "Estudo do possivel efeito de tratamentos de Medicina Tradicional Chinesa (MTC) na qualidade de vida e sintomas com esclerose múltipla (EM)".

Exmos. Senhores,

Eu, Maria José Meyer, em representação da instituição ANEM- Associação Nacional de Esclerose Múltipla, com NIPC 504467042, venho por este meio, aceitar a colaboração no "Estudo do possível efeito de tratamentos de Medicina Tradicional Chinesa (MTC) na qualidade de vida e sintomas com esclerose múltipla (EM)", proposto pelo elemento de coordenação do curso de Mestrado em Medicina Tradicional Chinesa do ICBAS- Universidade do Porto.

Agradecemos desde de já o vosso pedido de colaboração,

Com melhores cumprimentos,

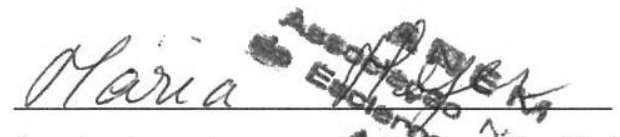

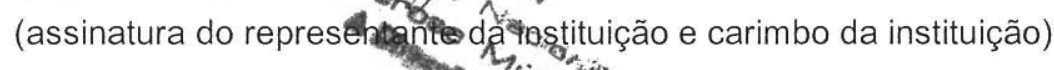

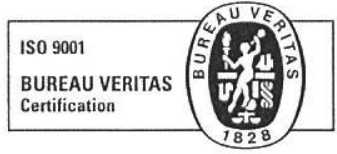

PT001725 

Effects of Acupuncture on Gait of Patients with Multiple Sclerosis

\section{ANNEX 2}





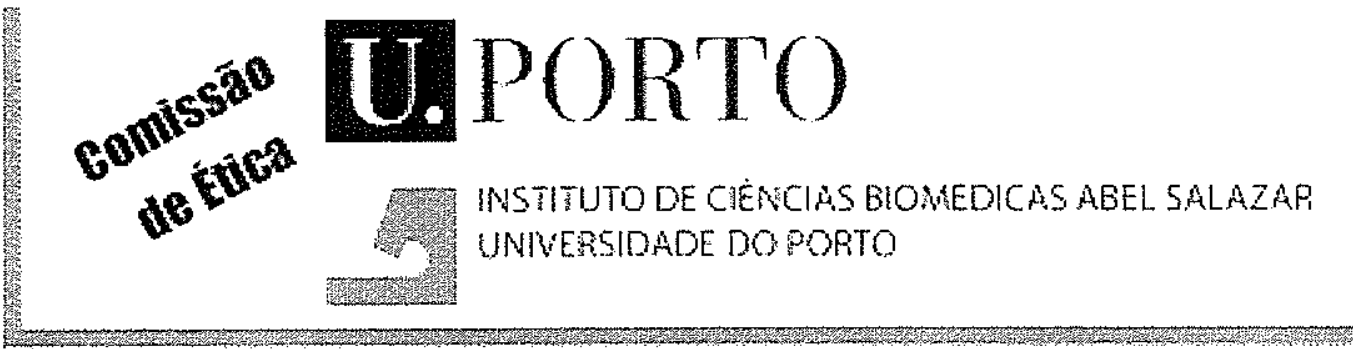

\section{Parecer da Comissão de Ética do ICBAS-UP}

\section{PROJETO NN 074/2014}

Título: Estudo do possivel efeito de tratamentos de Medicina tradicional Chinesa (MTC) na qualidade de vida e sintomas de doentes com Esclerose Múltipla Investigador Responsável: Maria Begoña Criado Alonso

Outros Investigadores: Maria João Santos

Orientador: Henry Johannes Greten

Duração do Projeto: até novembro de 2014

A Comissão de Ética do ICBAS-UP reuniu dia 03 de julho de 2014 no edifício do ICBAS Sala de reuniões do Departamento de Ciências do Comportamento, na presença de Liliana de Sousa, Manuel Vilanova, Margarida Araújo, Maria Antónia Gonçalves e Paulo Maia. Decidiu emitir parecer favorável à realização do projeto supracitado, por unanimidade.

Solicitamos que envie anualmente a esta Comissão um resumo dos resultados obtidos na sequência deste projeto.

Com os melhores cumprimentos,

Pela Comissão de Ética do ICBAS-UP,

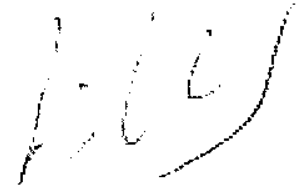

Prof. Doutora Liliana de Sousa (presidente)

To whom it may concern,

The above project is in accordance with the Portuguese law and the ICBAS-UP Ethics Committee criteria. 

ANNEX 3 



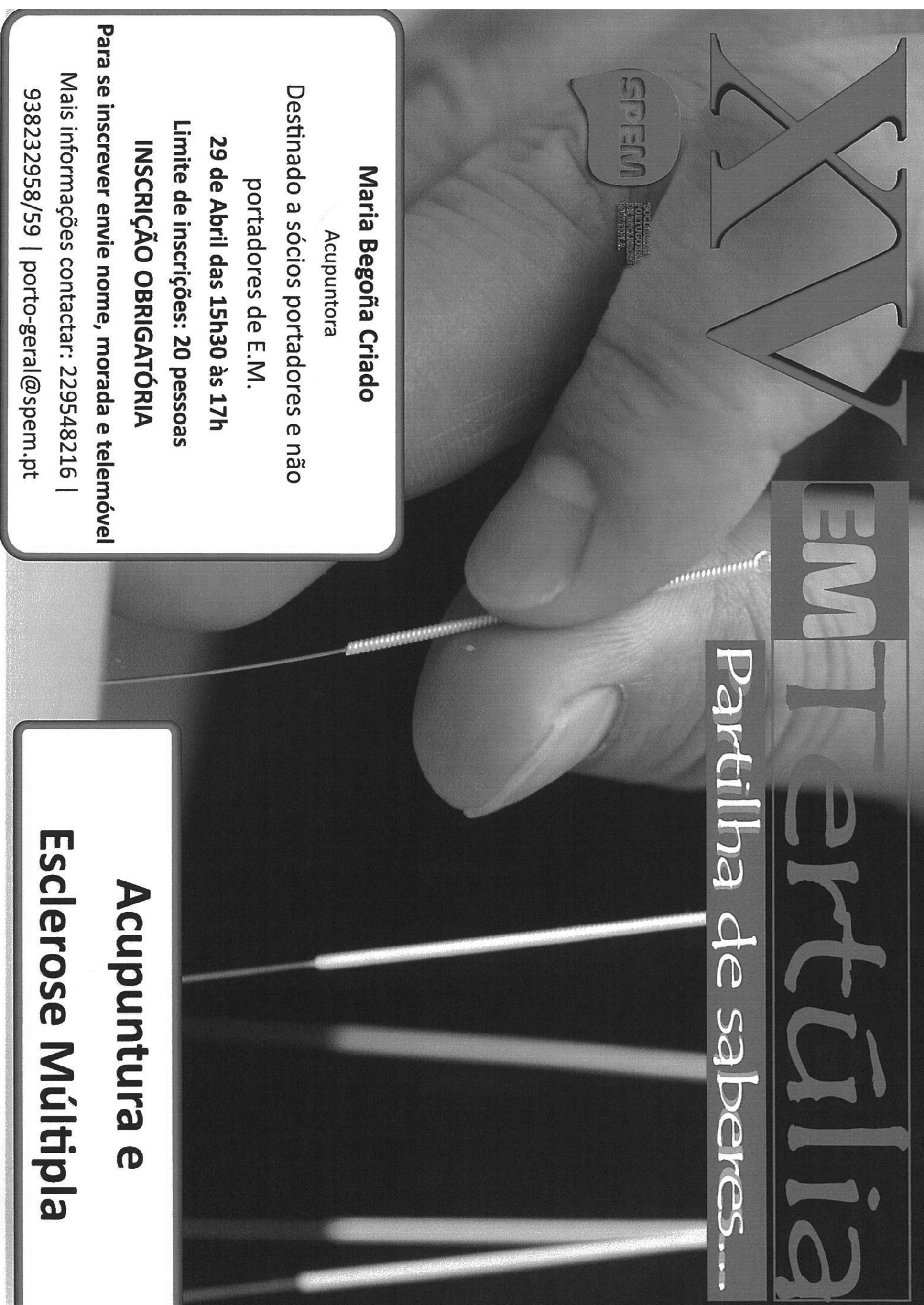


Effects of Acupuncture on Gait of Patients with Multiple Sclerosis

\section{ANNEX 4}





\title{
CONSENTIMENTO INFORMADO, LIVRE E ESCLARECIDO PARA PARTICIPAÇÃO EM PROJETOS DE DOCÊNCIA E/OU INVESTIGAÇÃo
}

\author{
de acordo com a Declaração de Helsínquia ${ }^{1}$ e a Convenção de Oviedo ${ }^{2}$ \\ Por favor, leia com atenção a seguinte informação. Se achar que algo está incorreto ou que não está \\ claro, não hesite em solicitar mais informaçżes. Se concorda com a proposta que Ihe foi feita, queira \\ assinar este documento.
}

Título do estudo: Estudo do possível efeito de tratamentos de Medicina Tradicional Chinesa (MTC) na qualidade de vida e sintomas de doentes com Esclerose Múltipla (EC)

Enquadramento: $O$ estudo será realizado em colaboração com a Sociedade Portuguesa de Esclerose Múltpla (SPEM)-Delegação Distrital do Porto e a Associação Nacional de Esclerose Múltipla (ANEM). Este estudo será realizado no âmbito do Mestrado em Medicina Tradicional Chinesa do ICBAS e coorientado pelo Prof. Henry Johannes Greten e pela Mestre Maria João Santos

Explicacão do estudo: Será realizado um estudo clínico prospectivo randomizado cego.

O objectivo do estudo é perceber se a terapia complementar da Medicina Tradicional Chinesa, a acupunctura, leva a melhoria de sintomas associados a problemas da marcha em doentes com Esclerose Múltipla do tipo Surto-Remissão. No sentido de avaliar os problemas relacionados com a marcha será realizado o teste dos 25 passos ("Timed 25 Foot Walking Test") que consiste em medir o tempo (em segundos) que demora a percorrer uma distância de, aproximadamente, 7.6 metros. No sentido de avaliar o impacto das alterações da marcha na qualidade de vida do doente será pedido a todos os participantes o preenchimento do questionário: "MSW-12 itens", que consiste em 12 perguntas relativas ao impacto dos problemas relacionados com a marcha no dia-a-dia do doente.

A participação é voluntária. Antes de iniciar o estudo serão realizados seminários de esclarecimento relativamente aos objetivos e desenho do estudo nas duas associaçöes de doentes que colaboram no trabalho: a ANEM e a SPEM.

O estudo se iniciará com a recolha de dados pessoais e clínicos de todos os doentes que aceitem fazer parte do mesmo, e que assinem o presente consentimento informado. Em todos os doentes será feita uma avaliação inicial da marcha. As avaliações da marcha serão realizadas mediante o "Timed 25 Foot Walking Test" e o "12-Item MS Walking Scale".

Após a avaliação inicial da marcha será realizada a intervenção propriamente dita (tratamento com acupunctura). Antes do tratamento, os participantes no estudo serão divididos aleatoriamente em dois grupos, de forma que cada doente receberá um único tratamento de acupunctura, os doentes do grupo A recebe o tratamento de "acupuntura verdadeira" e os do grupo B recebe o tratamento de "acupunctura falsa". Cada participante pode fazer parte de um ou de outro grupo de acupunctura de forma aleatória. 0 tratamento de acupunctura demora aproximadamente 20 minutos. Após a intervenção em todos os doentes será feita uma avaliação final da marcha (através do "Timed 25 Foot Walking Test") e pedido o preenchimento do questionário "MSW-12 itens" no dia seguinte ao tratamento. Os dados recolhidos serão depois tratados estatisticamente.

Para a recolha de dados, avaliação inicial da marcha, tratamento de acupunctura e avaliação final da marcha serão necessários aproximadamente 45 minutos. Todos os tratamentos serão realizados nas associações envolvidas, em gabinete próprio para garantir a privacidade. Tanto a ANEM como a SPEM farão o transporte dos doentes às respetivas associações.

O tratamento com acupunctura será efetuado por um profissional de saúde com formação em Medicina Chinesa Tradicional

O tratamento de acupunctura pretende contribuir para melhoria da capacidade da marcha, e com isso da qualidade de vida dos doentes com Esclerose Múltipla do tipo surto-remissão.

Note que não se espera que a acupunctura prejudique o tratamento convencional, nem haverá qualquer interferência no seu plano de tratamento habitual.

Todas as agulhas de acupuntura são esterilizadas e descartáveis (ou seja, de uso único). Antes da inserção das agulhas, a pele será desinfectada com uma solução anti-séptica alcoólica.

\footnotetext{
${ }^{1}{ }_{\text {http://portal.arsnorte.min-saude.pt/portal/page/portal/ARSNorte/Comiss\%C3\%A30\%20de\%20\%C3\%89tica/Ficheiros/Declaracao Helsinquia 2008.pdf }}$

${ }^{2}$ http://dre.pt/pdf1sdip/2001/01/002A00/00140036.pdf
} 
Os riscos associados a acupunctura são mínimos. Poderá sentir algum grau de dor ou desconforto e formigueiros no local das picadas com as agulhas de acupunctura. Mais raramente, poderá sentir ligeiras tonturas, ansiedade ou náuseas. É possivel que após o tratamento possam surgir ligeiros sangramentos, em particular se estiver a tomar a tomar medicamentos anti-agregantes (ex.:Aspirina, ácido acetilsalicílico) ou hipocoagulantes (ex.:Varfine $\otimes$ (varfarina); Sintrom $\otimes$, acenocumarol) efou aparecerem ligeiros hematomas no local onde foram inseridas as agulhas, que se resolverão espontaneamente. Caso esteja a tomar a medicaçăo acima referida deverá informar a equipa de investigação.

A responsabilidade de qualquer dano ocorrido durante o estudo é imputada à Escola de Heidelberg (HSCM), heidelbergschool@aol.com.

Sendo a participação voluntária os doentes terão o tempo necessário para ponderar sobre a sua participação neste estudo. São livres de consultar a opiniäo dos seus familiares ou amigos. Todos os participantes poderão a qualquer momento recusar continuar no estudo.

Condicöes e financiamento: $O$ estudo năo envolve qualquer tipo de pagamento de deslocaçőes ou contrapartidas uma vez que será realizado nas sedes das associações onde os doentes se deslocam normalmente. A participação é voluntária. O estudo mereceu Parecer favorável da Comissão de Ética do ICBAS-UP.

Confidencialidade e anonimato: Ao entrar neste estudo será garantida a privacidade, através de confidencialidade dos dados e regras do sigilo médico. A identificação dos participantes nunca será tornada pública. Todos os resultados obtidos serão devidamente codificados. Caso pretenda, o doente poderá ter acesso aos resultados, mas não os poderá divulgar ou usar para fins científicos. Os dados serăo apenas do conhecimento do investigador principal e dos orientadores do estudo e poderão ser posteriormente pubiicados em revistas científicas ou apresentados em eventos científicos. Será sempre mantido o anonimato dos participantes.

Agradecimentos e identificação do/a investigador/a e da pessoa que pede o consentimento, se for diferente

Para qualquer esclarecimento poderá entrar em contacto com Maria Begoña Criado (mestranda do Mestrado em Medicina Tradicional Chinesa do ICBAS) (Telemóvel: 932179516)

A equipa de investigação agradece a sua participação e está ao seu dispor para qualquer esclarecimento Assinatura(s): ...

Declaro ter lido e compreendido este documento, bem como as informações verbais que me foram fornecidas pela/s pessoas/s que acima assina/m e que considero suficientes. Foi-me garantida a possibilidade de, em qualquer altura, recusar participar neste estudo sem qualquer tipo de consequências. Desta forma, aceito participar neste estudo e permito a utilizaçăo dos dados que de forma voluntária forneço, confiando em que apenas serão utilizados para esta investigação e nas garantias de confidencialidade e anonimato que me são dadas pelo/a investigador/a.

Nome:

Assinatura:

Data: _ 1_1

ESTE DOCUMENTO, COMPOSTO DE 2 PÁGINA/S, É FEITO EM DUPLICADO: UMA VIA PARA O/A INVESTIGADOR/A, OUTRA PARA A PESSOA QUE CONSENTE 
ANNEX 5 



\section{Multiple Sclerose Waking Scale-12- MSWS-12 (versão portuguesa)}

Estas perguntas são sobre a sua dificuldade para andar nas duas últimas semanas devido à esclerose múltipla.

Para cada pergunta, por favor, marque o número que melhor descreve o seu grau de dificuldade.

Por favor, responda a todas as questões, mesmo que algumas delas pareçam semelhantes às outras, ou pareçam irrelevantes para você.

Se você não consegue andar de nenhuma maneira, por favor, marque aqui

\section{Nas duas últimas semanas, em quanto é que a esclerose múltipla:}

\section{Em nada-1; Um pouco-2; Moderadamente-3; Bastante-4; Extremamente-5}

1. Limitou a sua capacidade de andar?

$\begin{array}{lllll}1 & 2 & 3 & 4 & 5\end{array}$

2. Limitou a sua capacidade de correr?

$\begin{array}{lllll}1 & 2 & 3 & 4 & 5\end{array}$

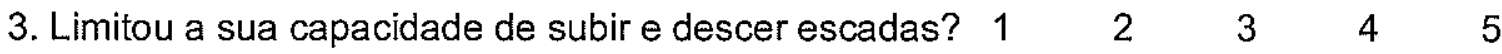

4. Dificultou fazer as coisas estando de pé?

$\begin{array}{lllll}1 & 2 & 3 & 4 & 5\end{array}$

5. Limitou o seu equilibrio quando estava de pé ou andando?

$\begin{array}{lllll}1 & 2 & 3 & 4 & 5\end{array}$

6. Limitou a distância que você é capaz de andar? $\quad \begin{array}{llllll}1 & 2 & 3 & 4 & 5\end{array}$

7. Aumentou o esforço necessário para você andar? $\quad \begin{array}{llllll}1 & 2 & 3 & 4 & 5\end{array}$

8. Fez você utilizar apoio para andar dentro de casa

(por exemplo: segurar em móveis, usar bengala etc.)? $\begin{array}{llllllll}1 & 2 & 3 & 4 & 5\end{array}$

9. Fez você utilizar apoio para andar fora de casa

(por exemplo: usar bengala, andador etc.)?

10. Reduziu a velocidade do seu andar?

$\begin{array}{lllll}1 & 2 & 3 & 4 & 5\end{array}$

11. Afetou o seu modo ou forma do andar?

$\begin{array}{lllll}1 & 2 & 3 & 4 & 5\end{array}$

12. Fez com que precisasse de se concentrar ou prestar atenção para andar?

$\begin{array}{lllll}1 & 2 & 3 & 4 & 5\end{array}$

Por favor, confira se fez um circulo em apenas UM número para CADA questão

Muito obrigado pela sua colaboração! 
